OECD Education Working Papers No. 138

\title{
Conditions and Practices \\ Associated with Teacher Professional Development and Its Impact on Instruction in TALIS 2013
} Darleen Opfer 
Organisation de Coopération et de Développement Économiques

Organisation for Economic Co-operation and Development

09-Aug-2016

DIRECTORATE FOR EDUCATION AND SKILLS

English - Or. English

CONDITIONS AND PRACTICES ASSOCIATED WITH TEACHER PROFESSIONAL

DEVELOPMENT AND ITS IMPACT ON INSTRUCTION IN TALIS 2013

By Darleen Opfer, RAND Corporation

OECD Education Working Paper No. 138

This working paper has been authorised by Andreas Schleicher, Director of the Directorate for Education and Skills, OECD.

Contact:

Darleen Opfer, RAND Corporation, dopfer@rand.org

JT03399686

Complete document available on OLIS in its original format

This document and any map included herein are without prejudice to the status of or sovereignty over any territory, to the delimitation of international frontiers and boundaries and to the name of any territory, city or area. 


\section{OECD EDUCATION WORKING PAPERS SERIES}

OECD Working Papers should not be reported as representing the official views of the OECD or of its member countries. The opinions expressed and arguments employed herein are those of the author(s).

Working Papers describe preliminary results or research in progress by the author(s) and are published to stimulate discussion on a broad range of issues on which the OECD works. Comments on Working Papers are welcome, and may be sent to the Directorate for Education and Skills, OECD, 2 rue André-Pascal, 75775 Paris Cedex 16, France.

This document and any map included herein are without prejudice to the status of or sovereignty over any territory, to the delimitation of international frontiers and boundaries and to the name of any territory, city or area.

The statistical data for Israel are supplied by and under the responsibility of the relevant Israeli authorities. The use of such data by the OECD is without prejudice to the status of the Golan Heights, East Jerusalem and Israeli settlements in the West Bank under the terms of international law.

You can copy, download or print OECD content for your own use, and you can include excerpts from OECD publications, databases and multimedia products in your own documents, presentations, blogs, websites and teaching materials, provided that suitable acknowledgement of OECD as source and copyright owner is given. All requests for public or commercial use and translation rights should be submitted to rights@oecd.org.

Comment on the series is welcome, and should be sent to edu.contact@oecd.org.

This working paper has been authorised by Andreas Schleicher, Director of the Directorate for Education and Skills, OECD.

www.oecd.org/edu/workingpapers

Copyright $@$ OECD 2016. 


\title{
ACKNOWLEDGEMENTS
}

This paper went through numerous reviews that improved the draft at each stage. I am grateful to all the reviewers, including Julie Belanger, Sonia Guerriero, Katarzyna Kubacka, Pablo Zoido, and others within the OECD Directorate for Education and Skills. Thanks also go to Emily Groves for formatting and editing the paper. The support provided by the Thomas J. Alexander Fellowship at the OECD made this paper and its analysis possible. The other fellows in the program contributed ideas, feedback on presentations, and a collegial environment that made working on this very enjoyable. Thanks also go to the leadership of RAND for giving me leave to accept the fellowship.

\begin{abstract}
A key lever for improving teaching is provision of effective professional development. This paper uses TALIS 2013 data to consider personal and school-level factors associated with teacher participation in effective professional development and reports of impact on instruction. Results of the analyses indicate that levels of teacher co-operation and instructionally-focused leadership in schools are associated with higher levels of effective professional development participation and reported instructional impact. Systems also vary significantly on the percentage of teachers in schools with supportive conditions and this is associated with differences in teacher participation in professional development types and reported instructional impact.
\end{abstract}

\section{RÉSUMÉ}

Offrir des possibilités de formation continue constitue assurément un levier efficace pour améliorer la qualité de l'enseignement. Ce document utilise les données issues de l'enquête TALIS 2013 pour étudier les facteurs, tant au niveau des individus qu'au niveau des établissements scolaires, qui interviennent dans la participation des enseignants à des programmes de formation continue. Il rend compte également de l'effet de ces programmes sur l'enseignement. Les résultats de cette étude indiquent que la coopération entre enseignants et un leadership des chefs d'établissement centré sur l'instruction sont associés à une plus grande participation des enseignants à des programmes de formation continue et à de plus grandes retombées pour l'enseignement. Le pourcentage d'enseignants qui bénéficient de conditions favorables dans leur environnement de travail varie de manière significative d'un système d'éducation à l'autre. Cette réalité est associée à des niveaux différents de participation à des programmes de formation continue et à des effets différents sur l'enseignement. 


\section{TABLE OF CONTENTS}

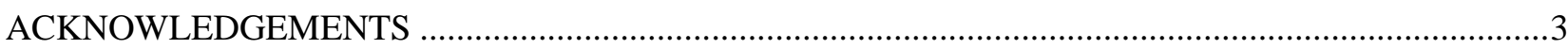

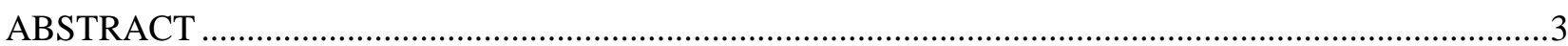

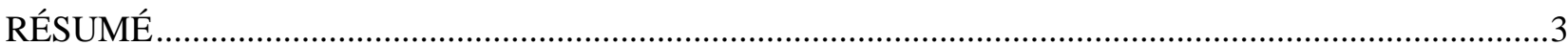

CONDITIONS AND PRACTICES ASSOCIATED WITH TEACHER PROFESSIONAL DEVELOPMENT AND ITS IMPACT ON INSTRUCTION IN TALIS 2013 ….....................................

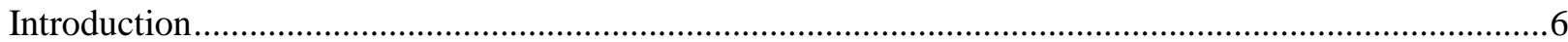

In what types of professional development activities do teachers report participating? ...........................12

Does participation in these different types of professional development matter? ....................................16

Are there school contexts that support more effective forms of professional development? ...................17

Do teachers participate in different types of professional development in different types of schools?.....21

How can policy makers support teacher professional development that improves teaching? ..................28

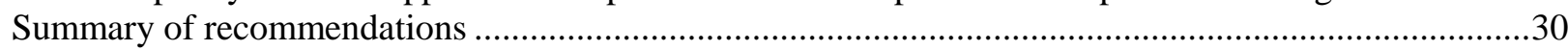

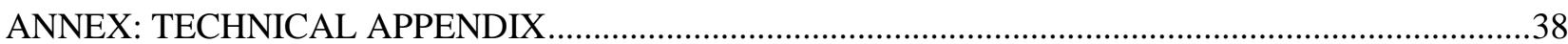

Identifying factors related to professional development for use in analysis ............................................38

Identifying school types and their relationship to professional development type and impact ................48

\section{Tables}

Table 1. Percentage of teachers indicating participation in non-school embedded professional development activities in the 12 months prior to TALIS 2013 administration........................................12 Table 2. Percentage of teachers indicating participation in school embedded professional development activities in the 12 months prior to TALIS 2013 administration........................................13

Table 3. Means and standard deviations for impacts on teaching knowledge and practice ...............17

Table 4. Teachers' beliefs about preparedness, self-efficacy, constructivist teaching and satisfaction

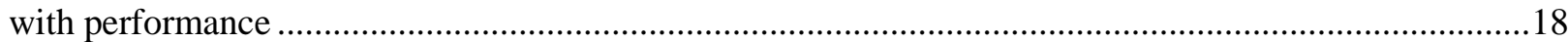

Table 5. Pearson correlations (two-tailed) between teacher beliefs and school embedded and nonschool embedded types of professional development ...........................................................................19

Table 6. Means and standard deviations for school condition items from TALIS 2013 ...................20

Table 7. Correlations between school conditions and school embedded and non-school embedded

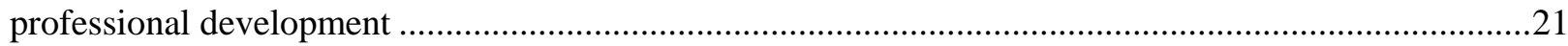

Table 8. Distribution of teachers responding to TALIS 2013, by cluster membership .....................22

Table 9. Item means for school conditions items, by cluster membership ......................................22

Table 10. Item means for teacher belief items, by cluster membership ..........................................23

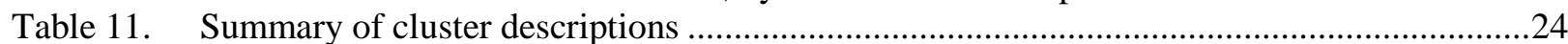

Table 12. Percentage of teachers in each cluster participation in non-school embedded professional

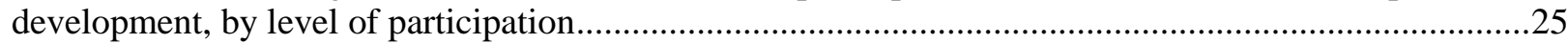

Table 13. Percentage of teachers in each cluster participating in school embedded professional

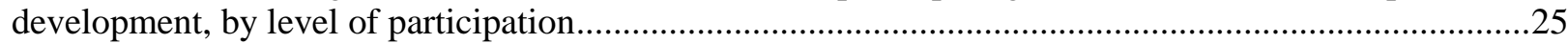

Table 14. Percentage of teachers reporting instructional impact from professional development

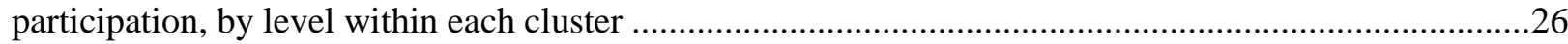

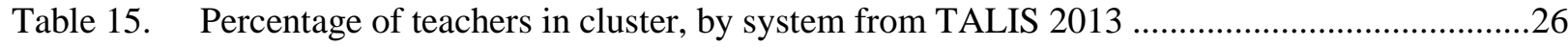

Table A.1 Means and standard deviations for items in school conditions factor ..................................38

Table A.2 Factor item loadings and fit statistics for school conditions factor .....................................39 
Table A.3 Means and standard deviations for teacher belief items . .39

Table A.4 Item loadings and fit statistics for teacher beliefs factor

Table A.5 Means and standard deviations for items in school embedded professional development factor

Table A.6 Factor loadings and fit statistics for school embedded professional development . .41

Table A.7 Means and standard deviations for non-school embedded factor items ...............................42

Table A.8 Factor loadings and fit statistics for non-school embedded factor ......................................42

Table A.9 Means and standard deviations for items in the professional development impact factor ....43

Table A.10 Factor loadings and fit statistics for professional development impact factor.......................43

Table A.11 Fit statistics for each factor by system............................................................................4

Table A.12 Relationship between type of professional development and teacher reported impact, by system

Table A.13 Correlation between type of PD and teacher belief, by system ...........................................46

Table A.14 Correlation between type of PD and school conditions, by system...................................47

Table A.15 Welch test for equality of means for school conditions ……..............................................48

Table A.16 Tukey's HSD test for differences between clusters for school conditions ...........................49

Table A.17 Welch test of equality of means for teacher beliefs........................................................51

Table A.18 Tukey's HSD test for differences between clusters for teacher beliefs ...............................52

\section{Figures}

Figure 1. Basic conceptualisation of professional development impact ...............................................6

Figure 2. Revised conceptualisation of professional development impact .........................................

Figure 3. Situational conceptualisation of professional development impact........................................

Figure 4. Full conceptual model of teach professional development impact......................................11

Figure 5. Differences between systems in standardised amount of teachers reporting participation in

non-school embedded professional development .................................................................................

Figure 6. Differences between systems in standardised amount of teachers reporting participation in

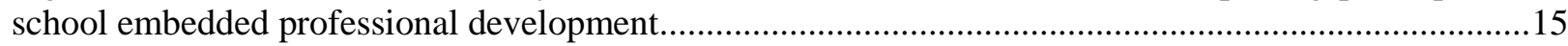

Figure 7. Comparison of mean reported participation in both types of professional development, by

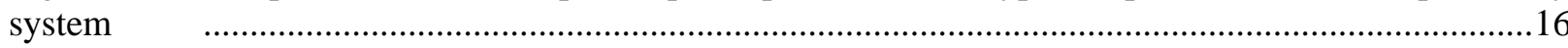

Figure 8. Illustration of the distribution of teachers across the clusters in each system graphically ....28 


\section{CONDITIONS AND PRACTICES ASSOCIATED WITH TEACHER PROFESSIONAL DEVELOPMENT AND ITS IMPACT ON INSTRUCTION IN TALIS 2013}

\section{Introduction}

Beyond initial teacher preparation, professional development is often considered the primary mechanism for improving teaching in many countries (Cohen and Hill, 2000; Darling-Hammond et al., 2009; Day and Sachs, 2005; European Commission, 2005; Fernandez, 2002; Guskey, 2003; Hassel, 1999; Hawley and Valli, 1998; Loucks-Horsley et al., 2003; National Commission on Teaching and America's Future, 1996; Timperley et al., 2007; Weiss and Pasley, 2009). Yet, despite its perceived importance, research on effective teacher professional development is scant (Weiss, 2009; Yoon et al., 2007) and much of the existing evidence criticises teacher professional development for failing to impact teachers' classroom practices and improve student achievement. This criticism is due, in part, because of the prevalence of single-shot learning opportunities that Hill (2009) has described as uninspired and of poor quality. Teacher professional development has also been criticised as "...intellectually superficial, disconnected from deep issues of curriculum and learning, fragmented, and noncumulative..." (Ball and Cohen, 1999: 3-4) and a "...patchwork of opportunities - formal and informal, mandatory and voluntary, serendipitous and planned..." (Wilson and Berne, 1999: 174) that lack coherence and a clear focus on classroom practices. Ingvarson (1998) describes this "traditional system of professional development" as in-service training where teachers have little control over learning and which is often disconnected from practical issues in the classroom.

Underlying this traditional notion of professional development is a very basic conceptualisation of how changes in teaching practice occur. Professional development opportunities that are disconnected from the school context assume that if teachers learn new knowledge and skills in these activities, they will go back to their classrooms, implement what they have learned, and students will be positively impacted (see Figure 1).

Figure 1. Basic conceptualisation of professional development impact

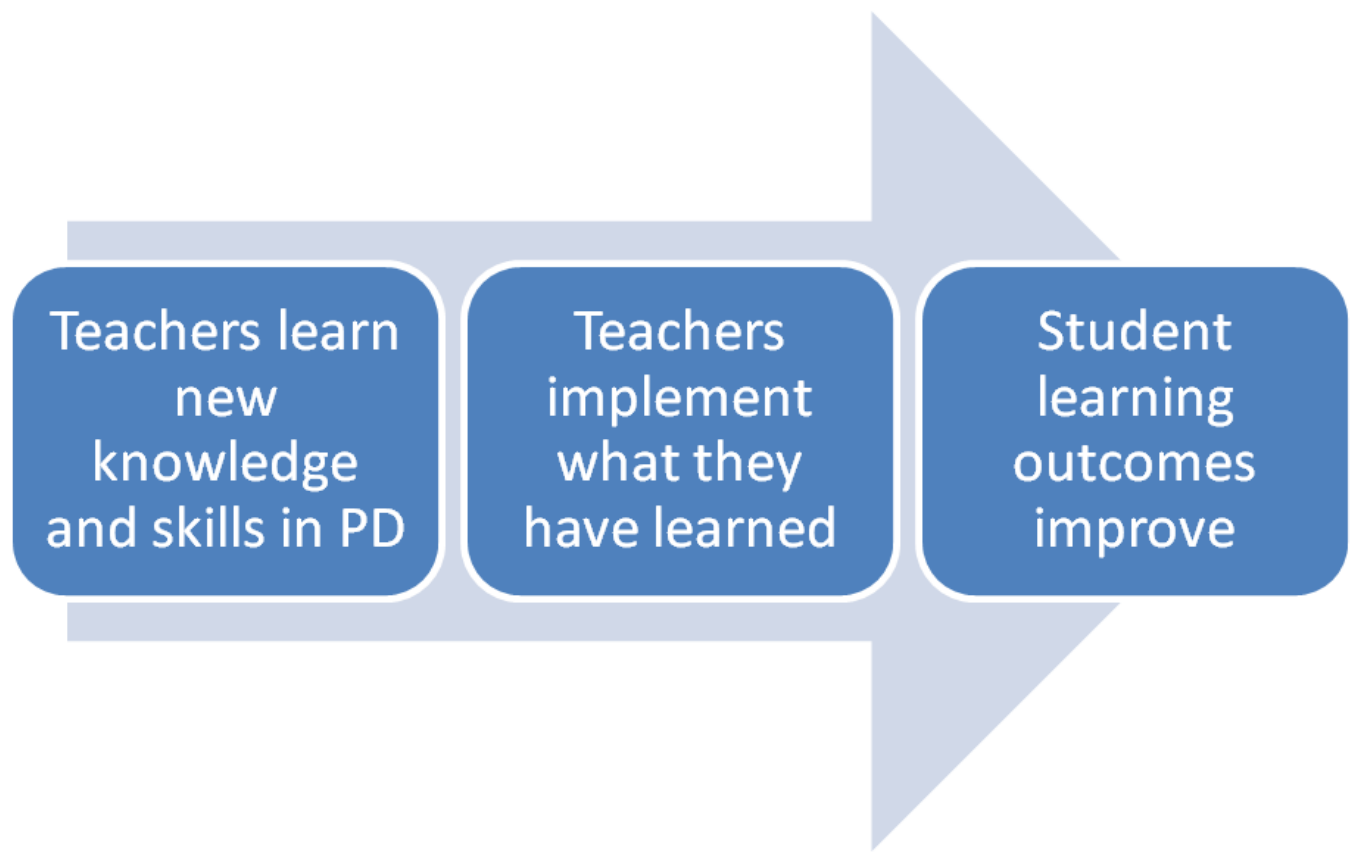


It should not be surprising that professional development with this simplistic understanding of the teacher change process has had disappointing results. As Yoon et al. (2007) have pointed out, improved student achievement will not result if one of these elements is weak or missing. Students cannot benefit from the teacher's professional learning if the teacher fails to learn new knowledge and skills or then fails to apply new learning in the classroom.

The majority of research on professional development has focused on understanding the elements of professional learning activities that ensure teachers gain knowledge and skills from the experience (Step 1 in the figure above). Often referred to as "effective professional development" or "high quality professional development", studies have focused on the characteristics of learning opportunities that lead to teachers implementing what they have learned.

Research has developed a consensus around characteristics of activities that make professional development more effective. One of the most researched characteristics is the relationship between duration of the activities and implementation of new teaching techniques. Teachers need time to learn, reflect, and accumulate new knowledge. Thus, professional development activities that are sustained over a period of time have been associated with improved teaching and student learning (Cohen and Hill, 2001; Desimone et al., 2002; Garet et al., 2001; McGill-Franzen et al., 1999; Supovitz, Mayer and Kahle, 2000, Weiss and Pasley, 2006). In a review of 1300 professional development studies, Yoon et al. (2007) found that those activities which had 14 or more hours of learning had a positive effect on student learning. Unfortunately, few professional development opportunities meet the 14 hour standard for impact; Yoon and his colleagues (2007) found that only 9 out of 1300 studies had activities of that duration.

In addition to the duration of the activities, form has also been shown to matter. Professional development that is active has been associated with teaching improvement (Snow-Renner \& Lauer, 2005). These types of activities allow teachers to practice new techniques and reflect on them (Carpenter et al., 1989; Cohen \& Hill, 2001; Desimone et al., 2002; Garet et al., 2001; Penuel et al., 2007; Saxe, Gearhart and Nasir, 2001; Supovitz, Mayer and Kahle, 2000). Relatedly, studies of professional development content have shown that it is most effective when focused on "...concrete tasks of teaching, assessment, observation and reflection..." (Darling-Hammond and McLaughlin, 1995: 598).

The importance of collaborative and collegial learning activities has also been identified as a characteristic of effective professional development (Darling-Hammond and McLaughlin, 1995; Knapp, 2003). Teachers who engage in professional learning with colleagues from their school site become "...engaged in a powerful form of staff development that allows them to grapple with 'real' issues related to the new content and instructional processes..." (Killion, 1999: 180). School change that extends beyond classroom improvement has also been shown to follow from collaborative approaches to professional development (Hord, 1997; Joyce and Calhoun, 1996; Louis, Marks and Kruse, 1996; McLaughlin and Talbert, 2001; Newman and Wehlage, 1997). This results from collaborative professional development often being a part of a coherent school reform effort (Elmore and Burney, 1997; Cohen and Hill, 2001; Garet et al., 2001; Penuel et al., 2007; Supovitz, Mayer and Kahle, 2000).

Thus, much of the research on effective teacher professional development has identified activities that are intensive, sustained, collaborative, and focused on materials and problems of practice as having more impact on teachers' knowledge, classroom practices and student achievement (See Figure 2 for revised conceptual model) (Ball and Cohen, 1999; Day and Sachs, 2005; European Commission, 2005; Garet et al., 2001; Joyce and Showers, 1995; Loucks-Horsley, Stiles and Hewson, 1996; Timperley et al., 2007; Wilson and Berne, 1999; Yoon et al., 2007). As Elmore (2004) asserts, “...improvement above all entails 'learning to do the right things in the setting where you work'..." (2004: 73). 
Figure 2. Revised conceptualisation of professional development impact

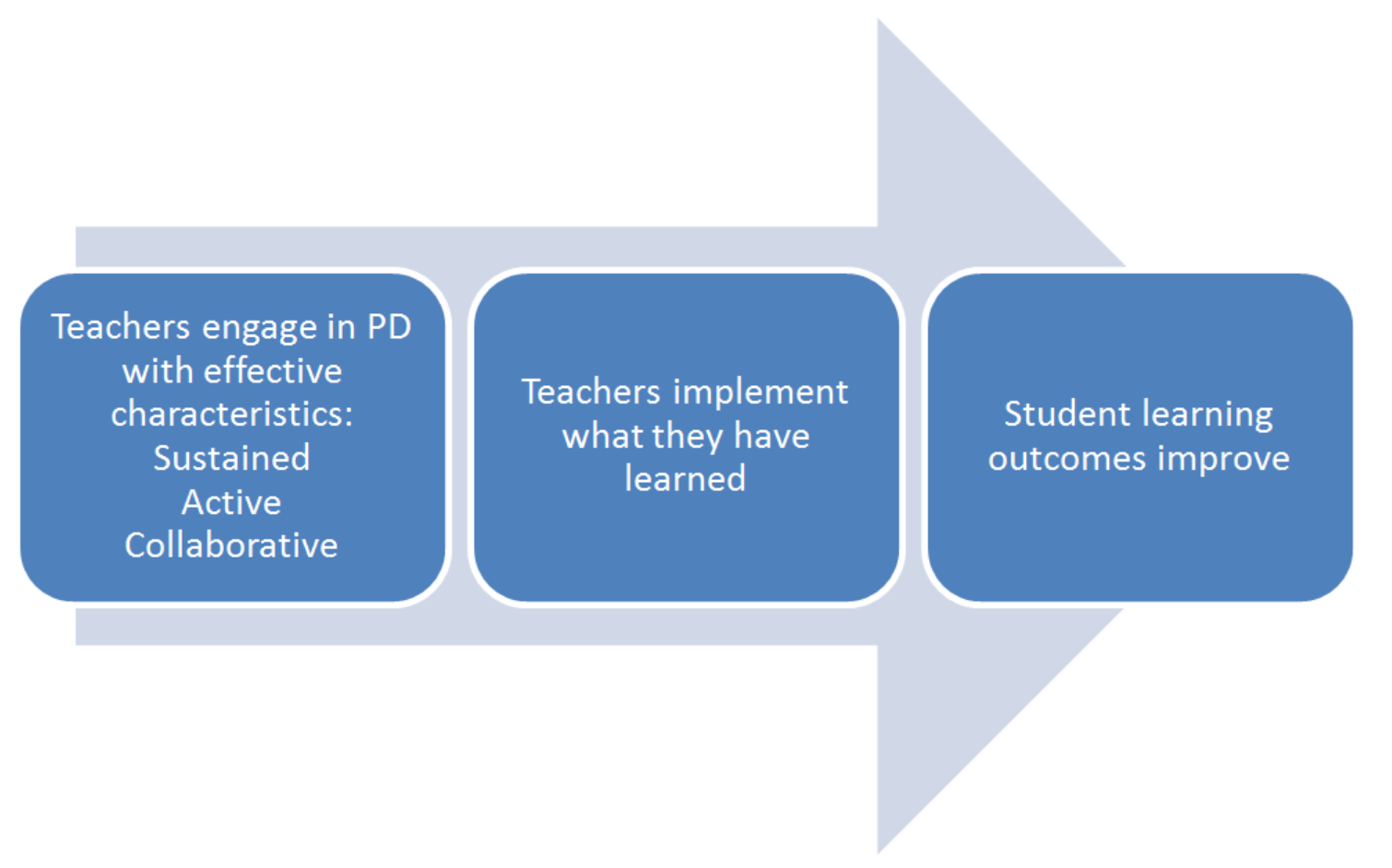

However, these effects have also been found to be mediated by prior teacher knowledge and practice in the classroom, a supportive school context and teacher beliefs that are conducive to learning and improvement (Cohen and Hill, 2000; Fishman et al., 2003; Garet et al., 2001; Guskey and Sparks, 2004; Hargreaves, 1998; Ingvarson et al., 2005; Kennedy, 1998; Loucks-Horsley and Matsumoto, 1999; Richardson, 2003a). Outside of the professional development literature, researchers have shown teaching and learning to be influenced by the context in which they occur (e.g. Anderson et al., 2000; Ball, 1997; Borko et al., 1997; Cobb and Bowers, 1999; Greeno, Collins and Resnick, 1996; Lave and Wenger, 1991; Leinhardt, 1988). Given this situational understanding, one must consider how both professional development activities and the implementation of the knowledge and skills gained are shaped by individual beliefs and practices, as well as school-level contexts (see Figure 3). 
Figure 3. Situational conceptualisation of professional development impact

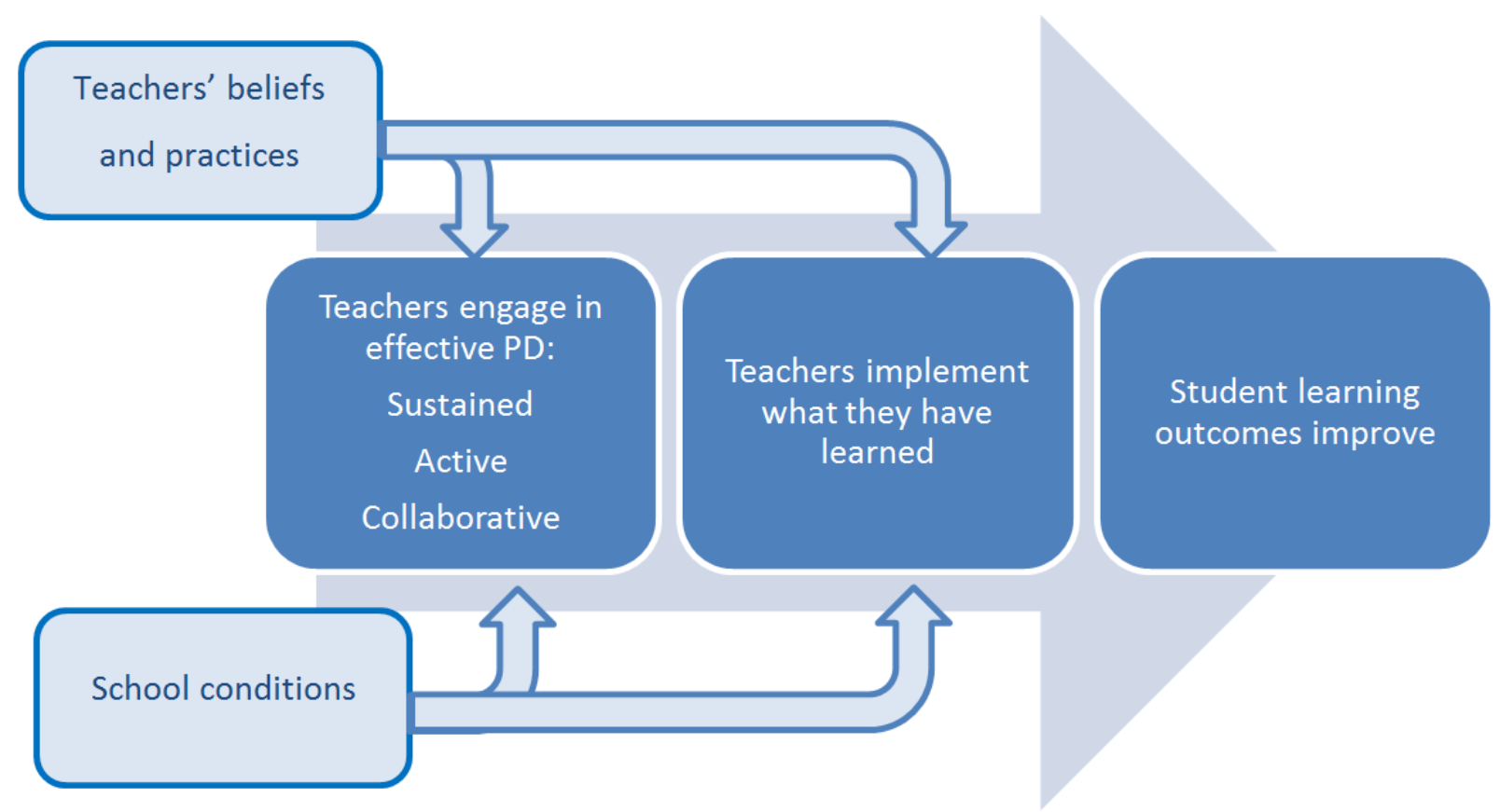

Richardson's (2003a) work has shown that the beliefs teachers bring to their work are shaped by three sources: personal experience, experience with school and instruction, and experience with formal knowledge (both subject and pedagogical). Likewise, Powell and Birrell (1992) and Novak and Knowles (1992) demonstrate that beliefs are heavily grounded in past and present experiences. These beliefs, in turn, impact teacher practices. In a survey of 1212 primary and secondary teachers in 32 schools in England, United Kingdom, teachers were asked how often certain learning practices occurred and how important teachers believed these practices were for creating opportunities for students to learn. The analysis showed that differences in the gaps between teachers' own assessment of their beliefs and practices were indicative of varying levels of inquiry, collaboration, valuing of learning, and critical and responsive learning (James et al., 2007; Pedder, 2006; Pedder, James and MacBeath, 2005; Pedder and MacBeath, 2008). Thus the intersection of experience and belief creates a powerful combination that determines not only the instructional decisions that teachers make (Raths, 2001; Richardson, 1996), but also what they themselves are willing to learn (Opfer and Pedder, 2011).

Specific teacher beliefs, including self-efficacy, feelings of preparedness, beliefs about classroom pedagogy, and satisfaction with their performance, have all been shown to impact whether teachers participate in professional development and also whether that participation leads to changes in classroom practice (Gamage and Hansson, 2006; Gregoire, 2003; Grider, 2008; Grove, Dixon and Pop, 2009; Hardre and Sullivan, 2008; Hargreaves, 1998; Harrison et al., 2008; Ingvarson et al., 2005; Jurow, 2009; Kuskovski, 2008; Meirinka et al., 2009; Moore, 2008; Mueller et al., 2008; Richardson, 2003b; Richardson and Placier, 2001; Zambo and Zambo, 2008). The relationship between these teacher beliefs and participation in professional development is often shown in the literature to be curvilinear. That is, we might expect that teachers with less self-assurance in their teaching ability would be more likely to undertake activities to improve their teaching. However, the extant research has shown that just the opposite occurs. For example, teachers with low self-efficacy are less likely than teachers with average self-efficacy to engage in professional learning and improvement (Grove, Dixon and Pop, 2009; Jurow, 2009; Kuskovski, 2008; Zambo and Zambo, 2008). Teachers with extremely high levels of self-efficacy, feelings of preparedness, etc. are also less likely to engage in professional development. 
Taken together, the literature on teacher beliefs about pedagogy, self-efficacy, preparedness, and satisfaction suggests that some teachers may have individual characteristics that lead them to be more amenable to professional learning and subsequent changes in their teaching practice than others. Teachers who hold constructivist pedagogical beliefs and who have typical levels of self-efficacy, feelings of preparedness for their teaching assignment and satisfaction with their teaching may participate in more learning activities and be more willing to try out new practices because they see teaching efficacy as incremental and changeable. ${ }^{1}$ Teachers who hold transmissive pedagogical beliefs, ${ }^{2}$ who suffer from low self-efficacy and feel unprepared or dissatisfied with their teaching, may be less interested in participating in professional development and also less willing to try new practices. Teachers with extremely high levels of belief in their teaching may also be less likely to participate in professional development because they hold static notions of teaching efficacy (Rodriguez et al., 2014).

In addition to individual teacher beliefs, the norms of the school, its structures and practices, influence teachers' professional learning (Galloway et al., 1982; Mortimore et al., 1990; Pollard, 1985; Rutter et al., 1979; Woods, Jeffery and Troman, 1997). School-level beliefs influence both individual and collective behaviour by creating norms of action (Sampson, Morenoff and Earls, 1999). Coleman's (1990, 1987, 1985) research on normative control confirmed that a group of teachers will sanction an individual teacher's practice when that practice violates group pedagogical beliefs. New or inexperienced teachers are especially vulnerable to constraining their practice to fit with collective pedagogical beliefs (Chester and Beaudin, 1996; Woolfolk Hoy and Burke-Spero, 2005).

In addition to school-level beliefs about teaching and learning, Hollingsworth's (1999) longitudinal study of primary mathematics teachers' professional development demonstrated that teachers encountered difficulties in implementing new practices in their classrooms because of unsupportive conditions in their schools: a lack of co-ordination and leadership, little collegial activity, and no obvious commitment to professional development in mathematics. Additionally, research literature on school conditions has shown both the type of leadership and the degree of co-operation among teachers to be important in supporting teachers to undertake more effective forms of professional development (Keith, 2008; Leithwood, Steinbach and Jantzi, 2002; Loucks-Horsely et al., 2003; Loucks-Horsely et al., 1996; Loxley et al., 2007; Nir and Bogler, 2008; Scribner, 1999; Timperley et al., 2007). This research indicates that leadership that is instructionally focused ${ }^{3}$ is often associated with teacher participation in professional development (Keith, 2008; Leithwood, Steinbach and Jantzi, 2002). Likewise, it is not surprising that in schools where teacher collaboration is more prevalent, teacher participation in professional development that involves collaboration also occurs (Loucks-Horsley et al., 2003; Loucks-Horsley, 1996; Loxley et al., 2007).

1. Constructivist beliefs are those held by teachers who feel that learning occurs as learners are actively involved in a process of meaning and knowledge construction as opposed to passively receiving information.

2. Transmissive pedagogical beliefs are those held by teachers who feel it is their duty to transmit their knowledge to their students. The primary teaching method for those who hold these beliefs tends to be lecture and learning is passive.

3. Instructional leadership focuses on learning for both students and adults and measures the effectiveness of learning by improvement in instruction and in the quality of student learning (Center for Educational Leadership, University of Washington, http://info.k-12leadership.org/4-dimensions-of-instructionalleadership). 
Although individual teachers' decisions about professional learning may result from a confluence of instructional practices, pedagogical beliefs, prior knowledge, and past experiences, school-level norms and decisions about professional learning may similarly play a role. To understand and explain why and how teachers learn, research suggests that in addition to focusing on the characteristics of the professional learning activities, we must also consider how a teacher's individual beliefs and practices interact with school-level beliefs and practices, and how both together may affect the activities and impacts of activities on teacher practices and student learning (see Figure 4 below).

Figure 4. Full conceptual model of teach professional development impact

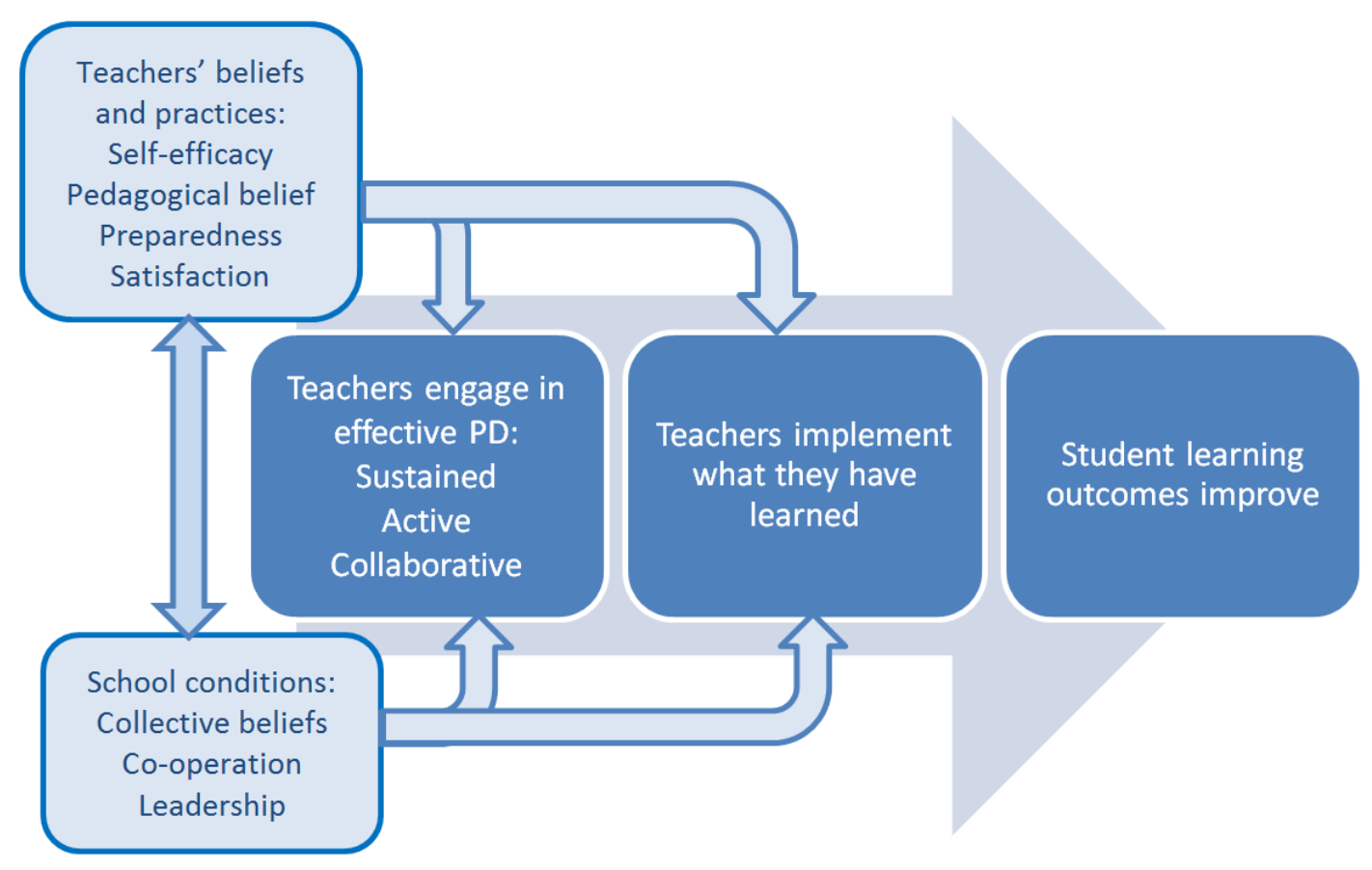

This paper uses Teaching and Learning International Survey (TALIS) 2013 data to explore the types of professional development activities in which teachers report engaging and the teacher beliefs and school norms and practices that influence whether this participation is associated with reported improved teaching practices. TALIS is an international, large-scale survey that focuses on the working conditions of teachers and the learning environment in schools. The analyses presented in this paper rely on data from the second cycle, TALIS 2013, which surveyed teachers and school leaders of lower secondary education in 34 countries and economies (OECD, 2014). The target sample size for TALIS is 200 randomly selected lower secondary schools per system, with 20 randomly selected teachers and 1 school leader per school resulting in a total sample size of 107655 for TALIS 2013.

The paper is structured around answering a series of questions:

- In what types of professional development activities do teachers report participating?

- Does participation in these different types of professional development matter?

- Are there school contexts that support engagement in more effective forms of professional development? 
- Do teachers report participating in different types of professional development in different types of schools?

- How can policy makers support engagement in teacher professional development that improves teaching?

In answering each question, data from TALIS are presented to consider patterns in response from teachers in general and teachers by system in order to understand how teacher professional development and its mediators vary internationally.

\section{In what types of professional development activities do teachers report participating?}

There are a wide variety of questions in TALIS that ask teachers about their prior participation in activities that could be considered professional development. As described in the technical appendix, these questions were factor analysed and two types of activities were identified. One type of activity includes the kinds of traditional professional development activities in which teachers have long participated: conferences, workshops, in-service training and qualification programmes. These activities often pull teachers out of their schools and classrooms in order for them to learn a new technique or skill. For the purposes of this paper, these kinds of activities will be referred to as "non-school embedded" professional development (see the technical appendix for factor fit statistics for the entire sample and for each system). Table 1 below shows the percentage of teachers who indicated they had participated in these activities in the 12 months prior to TALIS 2013 survey administration. Overall, teachers report having participated in these kinds of activities more than other kinds of professional development.

Table 1. Percentage of teachers indicating participation in non-school embedded professional development activities in the 12 months prior to TALIS 2013 administration

\begin{tabular}{|l|c|}
\hline Professional development activity & $\begin{array}{c}\text { Teachers indicating they participated } \\
\text { in activity in previous 12 months }\end{array}$ \\
\hline Courses and workshops & $70.5 \%$ \\
\hline Education conferences or seminars & $43.6 \%$ \\
\hline In-service training courses in business premises & $15.5 \%$ \\
\hline Qualification programme (e.g. a degree programme) & $19.2 \%$ \\
\hline
\end{tabular}

Source: OECD (2013), Teaching and Learning International Survey (TALIS): 2013 complete database, http://stats.oecd.org/index.aspx?datasetcode=talis 2013\%20.

The second type of professional development activities identified through factor analysis are those that more closely align with professional development literature indicating that ongoing, intensive, and collaborative activities, referred to here as "school embedded" professional development, have greater impacts on teaching practice (see the technical appendix for factor fit statistics for the entire sample and for each system). These kinds of activities include participating in professional development networks, undertaking collaborative research on problems of practice, peer observation and coaching, etc. Table 2 below shows the percentage of teachers who indicated they had participated in these activities in the 12 months prior to the TALIS 2013 survey administration. 
Table 2. Percentage of teachers indicating participation in school embedded professional development activities in the 12 months prior to TALIS 2013 administration

\begin{tabular}{l|l|c|}
\hline Professional development activity & $\begin{array}{c}\text { Teachers indicating they participated } \\
\text { in activity in previous 12 months }\end{array}$ \\
\hline Participation in a network of teachers & $36.7 \%$ \\
\hline Individual or collaborative research & $32.3 \%$ \\
\hline Mentoring and coaching & $30.5 \%$ \\
\hline Observe other teachers' classes and provide feedback & $33.1 \%$ \\
\hline $\begin{array}{l}\text { Work with teachers to ensure common standards for } \\
\text { assessing student progress }\end{array}$ & $79.7 \%$ \\
\hline Take part in collaborative professional learning & $61.0 \%$ \\
\hline $\begin{array}{l}\text { OECD (2013), Teaching and Learning International Survey } \\
\text { http://stats.oecd.org/index.aspx?datasetcode=talis 2013\%20. } 2013 \text { complete database, }\end{array}$ \\
\hline
\end{tabular}

Using the standardised factor scores for these two different types of professional development, we can compare the amount of each type of professional development participation as reported by teachers in TALIS 2013 participating countries and economies. Consistent with the item responses presented above, there is high participation in non-school embedded professional development activities in most countries and economies (mean $=3.0$ on a scale of 0 to 4 ). However, the differences between the systems with the highest level of teachers participating in these activities (France) and the lowest (Alberta, Canada) is more than a standard deviation; indicating the existence of significant differences in participation between countries and economies. Figure 5 below demonstrates this variation across participating systems. In addition to France, teachers in Chile, Italy and the Slovak Republic indicate participating in non-school embedded professional development activities at much higher than average levels. Conversely, teachers in Abu Dhabi, United Arab Emirates; Mexico; and Singapore and indicate participating in these types of activities at lower than average levels. 
Figure 5. Differences between systems in standardised amount of teachers reporting participation in nonschool embedded professional development

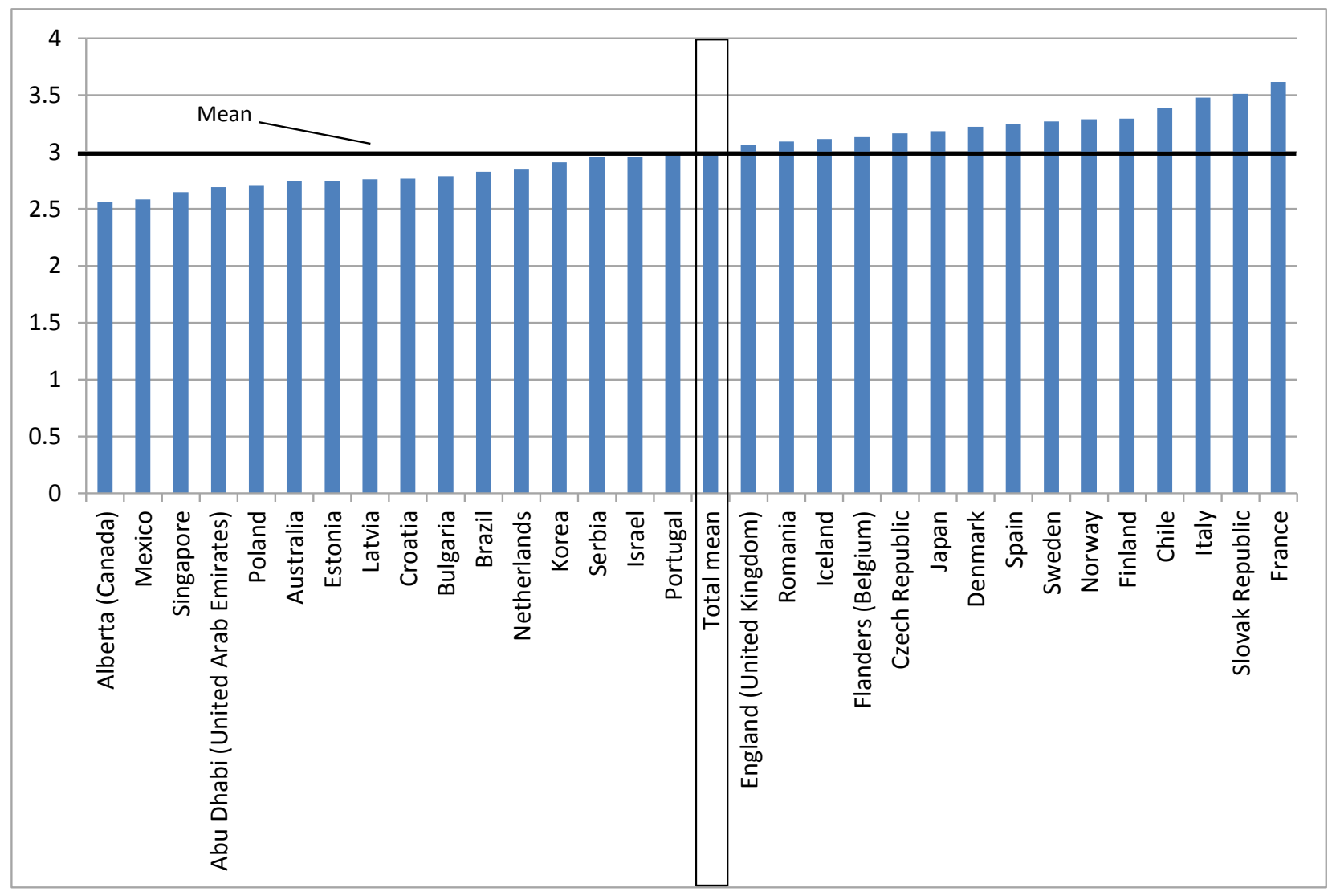

Countries and economies are ranked in ascending order, based on the mean reported participation in non-school embedded professional development.

Source: OECD (2013), Teaching and Learning International Survey (TALIS): 2013 complete database, http://stats.oecd.org/index.aspx?datasetcode=talis 2013\%20.

While there is a lower overall level of participation reported by teachers in school embedded professional development (mean $=2.0$ on a scale of 0 to 4 ), as with non-school embedded professional development, there are significant differences between systems in levels of teachers' reported participation. Figure 6 below demonstrates this variation between systems. Teachers in systems such as Finland; Flanders, Belgium; France; and Portugal indicate significantly below average participation in these types of activities whereas teachers in Abu Dhabi, United Arab Emirates; Australia; England, United Kingdom; and Singapore all indicated significantly higher than average levels of participation in school embedded professional development activities. 
Figure 6. Differences between systems in standardised amount of teachers reporting participation in school embedded professional development

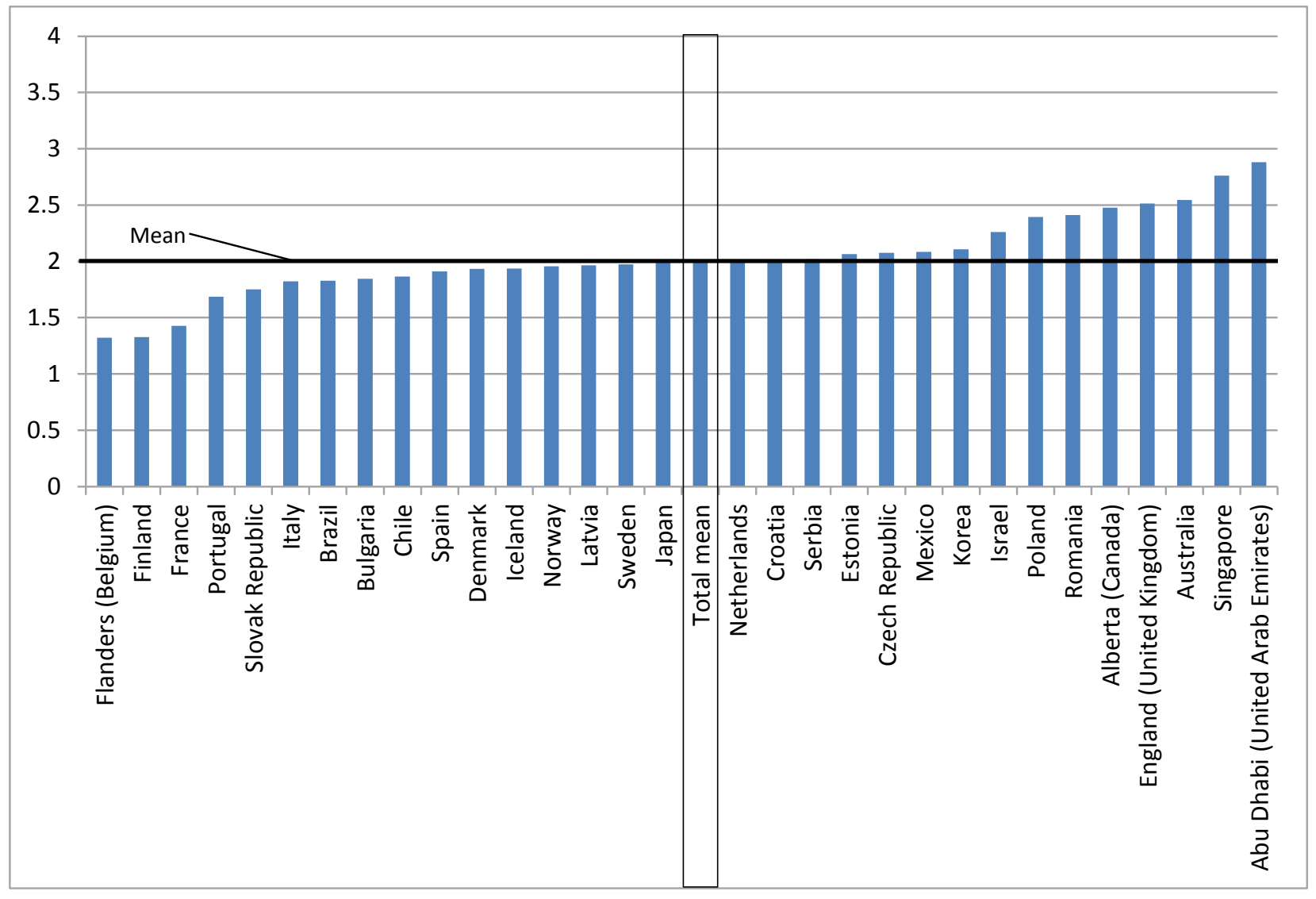

Countries and economies are ranked in ascending order, based on the mean reported participation in school embedded professional development.

Source: OECD (2013), Teaching and Learning International Survey (TALIS): 2013 complete database, http://stats.oecd.org/index.aspx?datasetcode=talis 2013\%20.

While it is the case that in most systems teachers report participating in non-school embedded professional development more often, the general trend is that there is an inverse releationship in participation between the two types. That is, if levels of participation in both types of professional development are overlayed (see Figure 7 below), systems where teachers report high levels of participation in school embedded professional development also tend to be the systems where teachers report lower levels of participation in non-school embedded professional development. In systems where teachers report high levels of participation in non-school embedded professional development, teachers also tend to report lower levels of participation in school embedded professional development. 
Figure 7. Comparison of mean reported participation in both types of professional development, by system

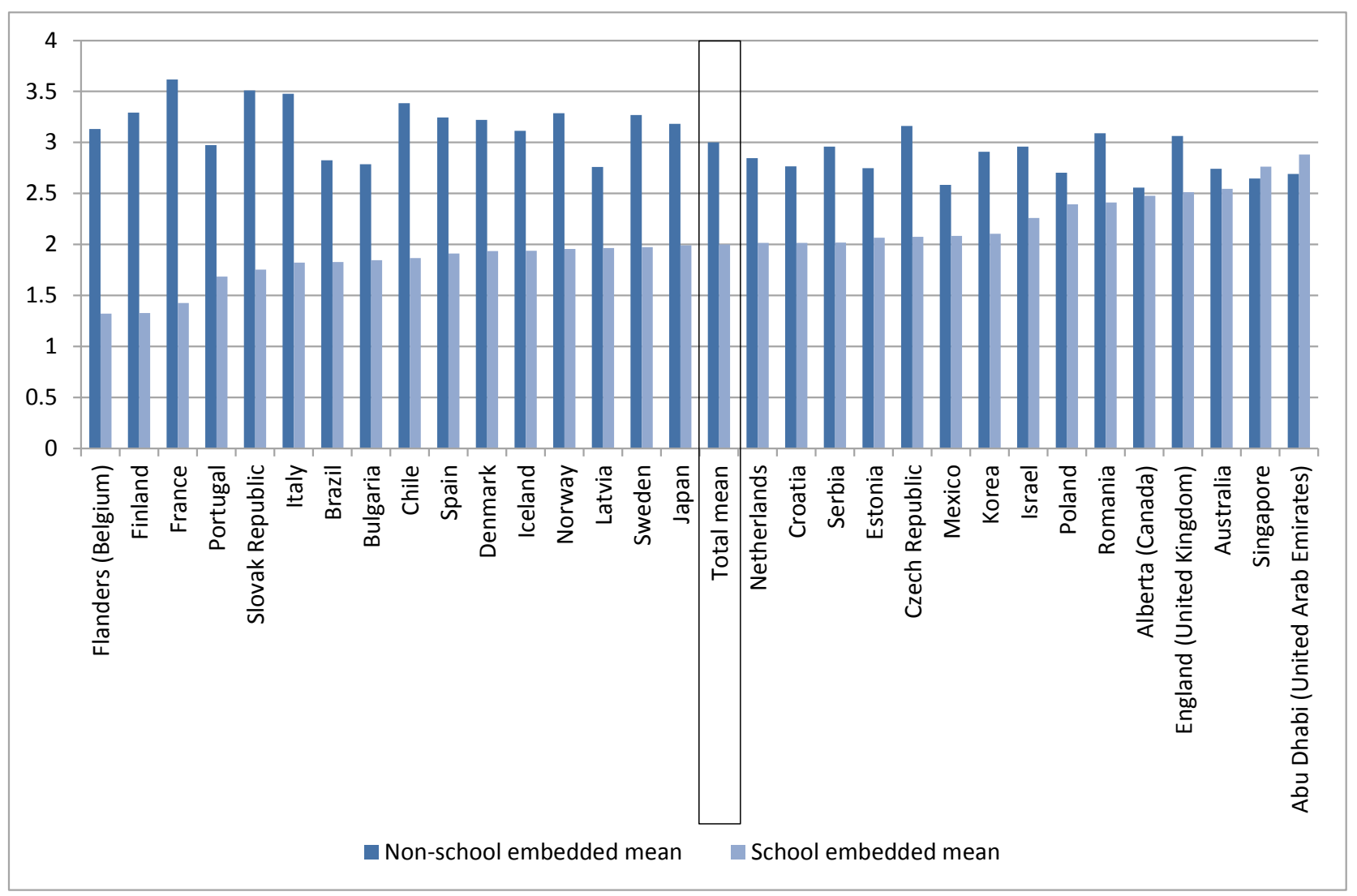

Systems are ranked in ascending order, based on the mean reported participation in school embedded professional development.

Source: OECD (2013), Teaching and Learning International Survey (TALIS): 2013 complete database, http://stats.oecd.org/index.aspx?datasetcode=talis $2013 \% 20$.

\section{Does participation in these different types of professional development matter?}

As indicated previously, the research literature on professional development has shown that participation in school embedded professional development activities is more likely to have a positive impact on teaching than participation in non-school embedded activities. Results from TALIS 2013 further support these findings. Teachers were asked whether the professional development activities in which they participated during the prior 12 months had a positive impact on 14 aspects of their work. In addition to impacts related to teachers' knowledge and practice, teachers were asked about impacts on student behaviour, school management, and use of technology. Again using factor analysis techniques described in the technical appendix, a factor was identified that summarises the teachers' reported impact on areas related to teacher knowledge and practice (see the technical appendix for factor fit statistics for the entire sample and for each system). As with previous studies of professional development impact, teachers in TALIS 2013 report low levels of impact on instruction from their participation. Table 3 below provides the means and standard errors for each of the items included in the factor. 
Table 3. Means and standard deviations for impacts on teaching knowledge and practice

\begin{tabular}{|l|c|c|}
\hline Estimate the positive impact where 1 = no impact and 4 = large impact & Mean & Std. error \\
\hline Knowledge and understanding of my subject field(s) & 1.70 & 0.001 \\
\hline Pedagogical competences in teaching my subject fields(s) & 1.67 & 0.001 \\
\hline Knowledge of the curriculum & 1.66 & 0.001 \\
\hline Student evaluation and assessment practices & 1.64 & 0.001 \\
\hline ICT (information and communication technology) skills & 1.62 & 0.001 \\
\hline Student behaviour and classroom management & 1.62 & 0.001 \\
\hline Teaching cross-curricular skills & 1.61 & 0.001 \\
\hline Student career guidance and counselling & 1.60 & 0.001 \\
\hline
\end{tabular}

Note: The data in this table are based on 102746 responses in each question.

Source: OECD (2013), Teaching and Learning International Survey (TALIS): 2013 complete database, http://stats.oecd.org/index.aspx?datasetcode=talis 2013\%20.

Using this professional development impact factor, we can consider the association between the two types of professional development identified (school embedded and non-school embedded) and the perceived impacts on teacher knowledge and practice as indicated by teachers in TALIS 2013. Using a Pearson correlation (two-tailed), we find that school embedded professional development has a positive, significant association with teacher reports of impact $(0.336, \mathrm{p} .=0.000)$ whereas non-school embedded professional development activities have a significant, negative association with reported professional development impact $(-0.413, \mathrm{p} .=0.000)$. This same pattern holds at the system-level with all correlations significant where $\mathrm{p}<0.01$ (see the technical appendix for individual system correlations between professional development type and impact). Thus, while higher levels of participation in school embedded professional development are associated with higher levels of reported impacts on teaching knowledge and practice, just the opposite is the case with non-school embedded professional development. The more teachers participate in non-school embedded professional development, the lower the impact on teaching knowledge and practice that is reported.

\section{Are there school contexts that support more effective forms of professional development?}

Existing literature has identified both individual teacher beliefs and school conditions that mediate participation in more effective professional development, such as the school embedded types.

TALIS 2013 asked teachers about their feelings of preparedness, their beliefs about teaching and their satisfaction with their performance. For the most part, teachers reported high levels of preparedness, self-efficacy, constructivist beliefs and satisfaction with performance. On a scale of one to four, where one indicates strong disagreement or no belief and four indicates strong agreement or a lot of belief, teachers on TALIS 2013 had beliefs with means all above three (see Table 4 below), indicating agreement and quite a bit of belief in the statements. 
Table 4. Teachers' beliefs about preparedness, self-efficacy, constructivist teaching and satisfaction with performance

\begin{tabular}{|c|c|c|}
\hline Teacher belief items & Mean & $\begin{array}{l}\text { Std. } \\
\text { error }\end{array}$ \\
\hline \multicolumn{3}{|l|}{ Feelings of preparedness } \\
\hline Prepared for teaching content of the subject(s) I teach & 3.53 & 0.000 \\
\hline Prepared for teaching pedagogy of the subject(s) I teach & 3.30 & 0.000 \\
\hline Prepared for teaching classroom practice in the subject(s) I teach & 3.36 & 0.000 \\
\hline \multicolumn{3}{|l|}{ Self-efficacy } \\
\hline Extent to which you can craft good questions for students & 3.22 & 0.000 \\
\hline Extent to which you can control disruptive behaviour in the classroom & 3.25 & 0.000 \\
\hline Extent to which you can make expectations about student behaviour clear & 3.37 & 0.000 \\
\hline Extent to which you can get students to follow classroom rules & 3.29 & 0.000 \\
\hline Extent to which you can calm a student who is disruptive or noisy & 3.21 & 0.000 \\
\hline Extent to which you can use a variety of assessment strategies & 3.14 & 0.000 \\
\hline Extent to which you can provide an alternative explanation & 3.38 & 0.000 \\
\hline Extent to which you can implement alternative instructional strategies & 3.08 & 0.000 \\
\hline \multicolumn{3}{|l|}{ Constructivist beliefs } \\
\hline Believe role as a teacher is to facilitate students' own inquiry & 3.29 & 0.000 \\
\hline Believe students learn best by finding solutions to problems on their own & 3.10 & 0.000 \\
\hline Believe students should be allowed to think of solutions themselves & 3.23 & 0.000 \\
\hline Believe thinking and reasoning processes are more important & 3.08 & 0.000 \\
\hline \multicolumn{3}{|l|}{ Satisfaction with performance } \\
\hline Am satisfied with my performance in this school & 3.16 & 0.000 \\
\hline
\end{tabular}

Note: The data in this table are based on 102746 responses for each item.

Source: OECD (2013), Teaching and Learning International Survey (TALIS): 2013 complete database, http://stats.oecd.org/index.aspx?datasetcode=talis 2013\%20.

Not unexpectedly, when we look at the relationship between these beliefs and participation in the two types of professional development - school embedded and non-school embedded - we see statistically significant relationships. Table 5 below demonstrates that, while small, the relationship between beliefs and school embedded professional development participation is positive, whereas the correlations between beliefs and non-school embedded professional development are all negative. This indicates that teachers with positive beliefs in their preparedness, self-efficacy, constructivist role and satisfaction with their performance are more likely to engage in more school embedded professional development. In contrast, teachers with these positive beliefs are less likely to engage in non-school embedded professional development less often. These results are mirrored at the system-level with all correlations for each system significant, $\mathrm{p}<0.01$ (see the technical appendix for individual system correlations between professional development type and teacher beliefs). Consistent with the research literature then, teachers who have the most need for effective professional development - those that have low feelings of preparedness, low self- 
efficacy, low constructivist teaching beliefs and low levels of satisfaction with their performance - are less likely to participate in the intensive, collaborative and school embedded type of professional learning.

Table 5. Pearson correlations (two-tailed) between teacher beliefs and school embedded and non-school embedded types of professional development (PD)

\begin{tabular}{|c|c|c|}
\hline Teacher belief items & $\begin{array}{c}\text { School } \\
\text { embedded } \\
\text { PD } \\
\text { correlation }\end{array}$ & $\begin{array}{c}\text { Non- } \\
\text { school } \\
\text { embedded } \\
\text { PD } \\
\text { correlation }\end{array}$ \\
\hline \multicolumn{3}{|l|}{ Feelings of preparedness } \\
\hline Prepared for teaching content of the subject(s) I teach & 0.072 & -0.041 \\
\hline Prepared for teaching pedagogy of the subject(s) I teach & 0.149 & -0.086 \\
\hline Prepared for teaching classroom practice in the subject(s) I teach & 0.137 & -0.083 \\
\hline \multicolumn{3}{|l|}{ Self-efficacy } \\
\hline Extent to which you can craft good questions for students & 0.107 & -0.070 \\
\hline Extent to which you can control disruptive behaviour in the classroom & 0.106 & -0.043 \\
\hline Extent to which you can make expectations about student behaviour clear & 0.099 & -0.070 \\
\hline Extent to which you can get students to follow classroom rules & 0.102 & -0.041 \\
\hline Extent to which you can calm a student who is disruptive or noisy & 0.101 & -0.032 \\
\hline Extent to which you can use a variety of assessment strategies & 0.178 & -0.095 \\
\hline Extent to which you can provide an alternative explanation & 0.113 & -0.076 \\
\hline Extent to which you can implement alternative instructional strategies & 0.195 & -0.106 \\
\hline \multicolumn{3}{|l|}{ Constructivist beliefs } \\
\hline Believe role as a teacher is to facilitate students' own inquiry & 0.075 & -0.070 \\
\hline Believe students learn best by finding solutions to problems on their own & 0.060 & -0.067 \\
\hline Believe students should be allowed to think of solutions themselves & 0.073 & -0.074 \\
\hline Believe thinking and reasoning processes are more important & 0.069 & -0.032 \\
\hline \multicolumn{3}{|l|}{ Satisfaction with performance } \\
\hline Am satisfied with my performance in this school & 0.124 & -0.055 \\
\hline
\end{tabular}

Note: All correlations are significant at the $p<0.000$ level.

Source: OECD (2013), Teaching and Learning International Survey (TALIS): 2013 complete database, http://stats.oecd.org/index.aspx?datasetcode=talis 2013\%20.

TALIS 2013 asked teachers how often they engaged in co-operative activities with other teachers in their school. On a scale from one to four where one would be never and four would be very often, teachers responded with medium levels of co-operation (see Table 6 below). TALIS 2013 also asked school leaders how often they took instructionally focused action in their schools. Again on a scale of one to four (where one $=$ never, four $=$ very often), principals tended to rate their level of action higher than teachers rated their level of co-operation (see Table 6 below). 
Table 6. Means and standard deviations for school condition items from TALIS 2013

\begin{tabular}{|l|c|c|}
\hline \multicolumn{1}{|c|}{ School conditions items } & Mean & $\begin{array}{c}\text { Std. } \\
\text { error }\end{array}$ \\
\hline \multicolumn{1}{|c|}{ Teacher co-operation } & 2.24 & 0.000 \\
\hline How often do you [teacher] exchange teaching materials with colleagues? & 2.49 & 0.000 \\
\hline $\begin{array}{l}\text { How often do you [teacher] engage in discussions about the learning development of specific } \\
\text { students? }\end{array}$ & 2.20 & 0.000 \\
\hline How often do you [teacher] attend team conferences? & \multicolumn{1}{|c|}{ Instructionally focused leadership } & 2.78 \\
\hline \multicolumn{1}{|c|}{0.000} \\
\hline $\begin{array}{l}\text { How frequently did you [school leader] take action in supporting co-operation among } \\
\text { teachers? }\end{array}$ & 2.84 & 0.000 \\
\hline $\begin{array}{l}\text { How frequently did you [school leader] take action to ensure teachers feel responsibility for } \\
\text { improving teaching skills? }\end{array}$ & 2.96 & 0.000 \\
\hline $\begin{array}{l}\text { How frequently did you [school leader] take action to ensure teachers feel responsibility for } \\
\text { learning outcomes }\end{array}$ & 2.000 \\
\hline
\end{tabular}

Note: Each of the means and standard errors reported in the table were calculated on 102746 teacher observations.

Source: OECD (2013), Teaching and Learning International Survey (TALIS): 2013 complete database, http://stats.oecd.org/index.aspx?datasetcode=talis $2013 \% 20$.

When we consider the correlations between these school conditions - teacher co-operation and instructionally focused leadership - and the two types of professional development, we see results consistent with previous research literature. The correlation between teacher co-operation and participation in school embedded professional development is moderately strong in the positive direction $(0.326-0.343$, Pearson, two-tailed correlation, $\mathrm{p}=0.01$ ). When higher levels of co-operation exist between teachers in a school, teachers are more likely to report participation in school embedded professional development (see Table 7 below). This is unsurprising given that school embedded professional development requires co-operation and co-ordination amongst teachers in a school.

The converse relationship is also present; when teachers report low levels of co-operation they also report higher levels of participation in non-school embedded PD. While not as strong, the relationship between instructionally focused leadership and participation in school embedded and non-school embedded professional development follows the same pattern (see also Table 7 below). Higher levels of instructionally focused leadership are associated with higher levels of teacher reported participation in school embedded professional development. Higher levels of instructionally focused leadership activity are also negatively correlated with teacher participation in non-school embedded professional development; indicating that teachers in schools with more instructionally focused leadership are less likely to participate in non-school embedded professional development.

This is the pattern for the international sample and within 21 of the systems and economies. In Australia, Chile, the Czech Republic, Italy, the Slovak Republic and Sweden, teacher co-operation and instructionally focused leadership had a positive association with both school and non-school embedded professional development. In Abu Dhabi, United Arab Emirates, these school conditions had a negative association with both school and non-school embedded professional development. In Serbia, these school conditions had a negative association with school embedded professional development and a positive relationship with non-school embedded. Neither Estonia nor Singapore had statistically significant associations between school conditions and either type of professional development. 
EDU/WKP(2016)12

Table 7. Correlations between school conditions and school embedded and non-school embedded professional development

\begin{tabular}{|l|c|c|}
\hline \multicolumn{1}{|c|}{ School conditions items } & \multicolumn{1}{|c|}{$\begin{array}{c}\text { School } \\
\text { embedded } \\
\text { PD }\end{array}$} & $\begin{array}{c}\text { Non-school } \\
\text { embedded } \\
\text { PD }\end{array}$ \\
\hline \multicolumn{1}{|c|}{ Teacher co-operation } & 0.343 & -0.090 \\
\hline How often do you [teacher] exchange teaching materials with colleagues? & 0.326 & -0.082 \\
\hline $\begin{array}{l}\text { How often do you [teacher] engage in discussions about the learning development of } \\
\text { specific students? }\end{array}$ & 0.332 & -0.075 \\
\hline How often do you [teacher] attend team conferences? & \multicolumn{2}{|c|}{} \\
\hline \multicolumn{1}{|c|}{ Instructionally focused leadership } & 0.061 & -0.033 \\
\hline $\begin{array}{l}\text { How frequently did you [school leader] take action in supporting co-operation among } \\
\text { teachers }\end{array}$ & 0.089 & -0.059 \\
\hline $\begin{array}{l}\text { How frequently did you [school leader] take action to ensure teachers feel responsibility } \\
\text { for improving teaching skills }\end{array}$ & 0.091 & -0.057 \\
\hline $\begin{array}{l}\text { How frequently did you [school leader] take action to ensure teachers feel responsibility } \\
\text { for learning outcomes }\end{array}$ & 0.091 \\
\hline
\end{tabular}

Note: Pearson, two-tailed correlations, all significant at the $p<0.01$ level.

Source: OECD (2013), Teaching and Learning International Survey (TALIS): 2013 complete database, http://stats.oecd.org/index.aspx?datasetcode=talis 2013\%20.

Results from TALIS 2013 are thus consistent with the available literature on conditions that support teacher participation in more effective types of professional development. When teachers have high levels of co-operation in a school, they tend to participate more often in professional development that is co-operative, sustained and focused on problems of their practice. Likewise, when there is more instructionally focused leadership action taking place in the school, teachers are more likely to participate in more effective types of professional development. When teachers lack these conditions, they are more likely to participate in less effective professional development that takes place outside of their school environment. The consistency of the relationships across these conditions suggests that there could be types of schools where engagement in different types of professional development activities takes place.

\section{Do teachers participate in different types of professional development in different types of schools?}

Cluster analysis allows us to group teachers by their responses on the school conditions and teacher beliefs items from TALIS 2013. These clusters of teacher responses give us profiles of the kind of schools in which teachers work (see the technical appendix for a more detailed discussion of the cluster analysis techniques used). Based on the grouping of teacher responses on the items about school conditions and those about instructional beliefs held by teachers, four school types can be identified. Teachers responding to TALIS 2013 are not evenly distributed across these clusters (see Table 8 below); approximately 60\% of teachers are in Clusters 1 (teacher-led schools) or 2 (school leader-led schools) while $40 \%$ are in either Clusters 3 (balanced, collaborative schools) or 4 (leader-dominant schools). 
Table 8. Distribution of teachers responding to TALIS 2013, by cluster membership

\begin{tabular}{l|l|c|c|}
\hline & Cluster & Percent of teachers in cluster & Number of teachers in cluster \\
\hline 1 & $24.5 \%$ & 24582 \\
\hline 2 & $34.3 \%$ & 34458 \\
\hline 3 & $27.7 \%$ & 27797 \\
\hline 4 & $13 \%$ & 13681 \\
\hline
\end{tabular}
http://stats.oecd.org/index.aspx?datasetcode=talis 2013\%20.

Teachers in each cluster differ in how they responded to questions about their school conditions (see Table 9 below). Teachers in Cluster 1 reported higher than average levels of teacher co-operation, but their school leaders reported lower than average levels of instructionally focused leadership - what we might call a teacher-led school environment. In Cluster 2, teachers reported lower than average teacher co-operation and their school leaders reported above average instructionally focused leadership - a school leader-led school environment. Teachers and school leaders in Cluster 3 reported higher than average levels of both teacher co-operation and instructionally focused school leadership - a balanced, highly collaborative school environment. Finally, teachers in Cluster 4 reported lower than average teacher co-operation and the school leaders for these teachers reported very high levels of instructionally focused leadership - a leader-dominant environment.

Table 9. Item means for school conditions items, by cluster membership

\begin{tabular}{|l|c|c|c|c|c|}
\hline \multicolumn{1}{|c|}{ School conditions items } & $\begin{array}{c}\text { Cluster } \\
\mathbf{1}\end{array}$ & $\begin{array}{c}\text { Cluster } \\
\mathbf{2}\end{array}$ & $\begin{array}{c}\text { Cluster } \\
\mathbf{3}\end{array}$ & $\begin{array}{c}\text { Cluster } \\
\mathbf{4}\end{array}$ & $\begin{array}{c}\text { Total } \\
\text { average }\end{array}$ \\
\hline \multicolumn{2}{|c|}{ Teacher co-operation } \\
\hline $\begin{array}{l}\text { How often do you [teacher] exchange teaching materials } \\
\text { with colleagues? }\end{array}$ & 2.25 & 2.17 & 2.35 & 2.12 & 2.24 \\
\hline $\begin{array}{l}\text { How often do you [teacher] engage in discussions about the } \\
\text { learning development of specific students? }\end{array}$ & 2.54 & 2.42 & 2.61 & 2.31 & 2.49 \\
\hline How often do you [teacher] attend team conferences? & 2.32 & 2.12 & 2.28 & 2.00 & 2.20 \\
\hline \multicolumn{4}{|c|}{ Instructionally focused leadership } & & \\
\hline $\begin{array}{l}\text { How frequently did you [school leader] take action in } \\
\text { supporting co-operation among teachers? }\end{array}$ & 2.12 & 2.86 & 2.83 & 3.66 & 2.78 \\
\hline $\begin{array}{l}\text { How frequently did you [school leader] take action to ensure } \\
\text { teachers feel responsibility for improving teaching skills? }\end{array}$ & 2.03 & 2.96 & 2.92 & 3.84 & 2.84 \\
\hline $\begin{array}{l}\text { How frequently did you [school leader] take action to ensure } \\
\text { teachers feel responsibility for learning outcomes? }\end{array}$ & 2.22 & 3.05 & 3.05 & 2.86 & 2.96 \\
\hline
\end{tabular}

Note: All differences are significant at the $p<.05$ level except between Cluster 2 and 3 on the leadership question concerning teacher responsibility for learning outcomes.

Source: OECD (2013), Teaching and Learning International Survey (TALIS): 2013 complete database, http://stats.oecd.org/index.aspx?datasetcode=talis 2013\%20.

Teachers in each cluster also significantly differ in their perceptions of their preparedness, self-efficacy, constructivist beliefs and satisfaction with performance (see Table 10 below). However, these ratings are fairly consistent across these different types of beliefs. Teachers in Cluster 1 report, across all items, low levels of feelings of preparedness, self-efficacy, constructivist beliefs and satisfaction with performance. Teachers in Cluster 2 report the lowest levels of belief on all items. Teachers in Cluster 3 
report very high levels of teacher belief. And teachers in Cluster 4 report moderate levels of belief across all items (while significant, only slightly above or below the average response for all teachers).

Table 10. Item means for teacher belief items, by cluster membership

\begin{tabular}{|c|c|c|c|c|c|}
\hline Teacher beliefs & $\begin{array}{c}\text { Cluster } \\
1\end{array}$ & $\begin{array}{c}\text { Cluster } \\
2 \\
\end{array}$ & $\begin{array}{c}\text { Cluster } \\
3 \\
\end{array}$ & $\begin{array}{c}\text { Cluster } \\
4\end{array}$ & $\begin{array}{c}\text { Total } \\
\text { average }\end{array}$ \\
\hline \multicolumn{6}{|c|}{ Feelings of preparedness } \\
\hline Prepared for teaching content of the subject(s) I teach & 3.42 & 3.4 & 3.78 & 3.5 & 3.53 \\
\hline Prepared for teaching pedagogy of the subject(s) I teach & 3.16 & 3.11 & 3.64 & 3.26 & 3.3 \\
\hline $\begin{array}{l}\text { Prepared for teaching classroom practice in the subject(s) I } \\
\text { teach }\end{array}$ & 3.21 & 3.15 & 3.71 & 3.33 & 3.36 \\
\hline \multicolumn{6}{|c|}{ Self-efficacy } \\
\hline Extent to which you can craft good questions for students & 3.05 & 2.88 & 3.72 & 3.14 & 3.21 \\
\hline $\begin{array}{l}\text { Extent to which you can control disruptive behaviour in the } \\
\text { classroom }\end{array}$ & 2.93 & 2.83 & 3.65 & 3.11 & 3.14 \\
\hline $\begin{array}{l}\text { Extent to which you can make expectations about student } \\
\text { behaviour clear }\end{array}$ & 3.23 & 3.09 & 3.85 & 3.34 & 3.38 \\
\hline $\begin{array}{l}\text { Extent to which you can get students to follow classroom } \\
\text { rules }\end{array}$ & 2.9 & 2.75 & 3.59 & 3.04 & 3.08 \\
\hline $\begin{array}{l}\text { Extent to which you can calm a student who is disruptive or } \\
\text { noisy }\end{array}$ & 3.22 & 3.18 & 3.45 & 3.25 & 3.29 \\
\hline $\begin{array}{l}\text { Extent to which you can use a variety of assessment } \\
\text { strategies }\end{array}$ & 3.02 & 3.02 & 3.22 & 3.11 & 3.1 \\
\hline Extent to which you can provide an alternative explanation & 3.16 & 3.14 & 3.37 & 3.22 & 3.23 \\
\hline $\begin{array}{l}\text { Extent to which you can implement alternative instructional } \\
\text { strategies }\end{array}$ & 3.03 & 3.01 & 3.2 & 3.05 & 3.08 \\
\hline \multicolumn{6}{|c|}{ Constructivist beliefs } \\
\hline Believe role as a teacher is to facilitate students' own inquiry & 3.07 & 2.95 & 3.65 & 3.19 & 3.22 \\
\hline $\begin{array}{l}\text { Believe students learn best by finding solutions to problems } \\
\text { on their own }\end{array}$ & 3.11 & 2.94 & 3.74 & 3.2 & 3.25 \\
\hline $\begin{array}{l}\text { Believe students should be allowed to think of solutions } \\
\text { themselves }\end{array}$ & 3.23 & 3.09 & 3.83 & 3.32 & 3.37 \\
\hline Believe thinking and reasoning processes are more important & 3.13 & 2.98 & 3.78 & 3.24 & 3.29 \\
\hline \multicolumn{6}{|c|}{ Satisfaction with performance } \\
\hline Am satisfied with my performance in this school & 3.05 & 3 & 3.39 & 3.13 & 3.16 \\
\hline
\end{tabular}

Note: All differences are significant at the $\mathrm{p}<.05$ level.

Source: OECD (2013), Teaching and Learning International Survey (TALIS): 2013 complete database, http://stats.oecd.org/index.aspx?datasetcode=talis $2013 \% 20$.

Table 11 below summarises for each cluster how teachers and school leaders perceive the school conditions and how teachers rate their own beliefs. Teachers in teacher-led schools (Cluster 1) with high teacher co-operation and low levels of instructionally focused leadership report low levels of teacher beliefs. Teachers in leader-led schools (Cluster 2) report low teacher co-operation, moderate instructionally focused leadership and very low levels of teacher belief. Teachers in balanced, collaborative schools (Cluster 3) report high levels of both teacher co-operation and instructionally focused leadership and very high levels of teacher belief. Teachers in leader dominated schools report low levels of teacher co-operation, very high levels of instructionally focused leadership and moderate levels of teacher belief. It is quite interesting that in teacher-led schools, teachers would report low levels of preparedness, 
self-efficacy, constructivist beliefs and satisfaction with performance. It is only in the balanced, highly collaborative schools that teachers report high levels of these beliefs although teachers in leader dominated schools tend to have higher levels of belief than either the teacher-led or the leader-led schools.

These findings suggest that teacher beliefs are sensitive to teacher co-operation in a curvilinear way. Too much co-operation amongst teachers, where teacher co-operation dominates the environment, may cause teachers to be less assured as individuals. Too little teacher co-operation, as in the leader-led schools, may also lead to less assured teachers. Just the right amount of teacher co-operation - balanced by strong leadership (as in the balanced, collaborative schools) - results in high teacher instructional beliefs. The amount of leadership also appears to matter. Very high leadership (as in the leader dominated schools) may compensate for low levels of teacher co-operation to lead to moderate teacher beliefs. Otherwise, the relationship between teacher belief and instructionally focused leadership appears to be fairly linear with teacher beliefs rising as instructionally focused leadership raises.

Table 11. Summary of cluster descriptions

\begin{tabular}{|l|c|c|c|}
\hline & Teacher co-operation & $\begin{array}{c}\text { Instructionally focused } \\
\text { leadership }\end{array}$ & Teacher beliefs \\
\hline $\begin{array}{l}\text { Cluster 1 - teacher- } \\
\text { led }\end{array}$ & High & Low & Low \\
\hline $\begin{array}{l}\text { Cluster 2 - school } \\
\text { leader-led }\end{array}$ & Low & Moderate & High low \\
\hline $\begin{array}{l}\text { Cluster 3 - balanced, } \\
\text { highly collaborative }\end{array}$ & High & High & Moderate \\
\hline $\begin{array}{l}\text { Cluster 4 - leader } \\
\text { dominant }\end{array}$ & Low & Very high & complete database, \\
\hline
\end{tabular}

http://stats.oecd.org/index.aspx?datasetcode=talis 2013\%20.

Given these differences in conditions, which have been shown to support professional development of teachers, we would expect to see differences between the clusters in participation of teachers in school embedded and non-school embedded professional development. Table 12 below shows the percentage of teachers in each cluster at different levels of participation in non-school embedded professional development. With one being a low level of participation and four being a high level of participation, we see that teachers in the teacher-led and leader-led school clusters have the highest levels of participation in non-school embedded professional development. The teacher-led cluster had $62 \%$ of its teachers' participation in non-school embedded professional development at levels three and four. Teachers in the school leader-led schools had $62.4 \%$ of their teachers participating at these levels. Teachers in the balanced, collaborative school cluster (Cluster 3) have more teachers reporting the lowest level of participation in non-school embedded professional development $(10.1 \%)$, with teachers in the leaderdominant (Cluster 4) schools reporting slightly less participation at the lowest level (9.4\%) than those is the balanced, collaborative cluster, but still at higher levels than the teacher- (Cluster 1) (5.8\%) and school leader-led (Cluster 2) clusters $(6.5 \%)$. 
Table 12. Percentage of teachers in each cluster participation in non-school embedded professional development, by level of participation

\begin{tabular}{|c|c|c|c|c|}
\hline \multirow{2}{*}{\begin{tabular}{c} 
Level of teacher participation \\
\cline { 2 - 5 }
\end{tabular}} & \multicolumn{4}{|c|}{ Non-school embedded professional development by cluster } \\
\cline { 2 - 5 } & $1-$ teacher led & $2-$ leader led & $\begin{array}{c}3-\text { balanced, } \\
\text { collaborative }\end{array}$ & $\begin{array}{c}4-\text { leader } \\
\text { dominant }\end{array}$ \\
\hline 1 low & $5.8 \%$ & $6.5 \%$ & $10.1 \%$ & $9.4 \%$ \\
\hline 2 & $31.9 \%$ & $31.0 \%$ & $34.3 \%$ & $31.8 \%$ \\
\hline 3 & $37.7 \%$ & $36.3 \%$ & $34.6 \%$ & $35.3 \%$ \\
\hline $4=$ high & $24.6 \%$ & $26.1 \%$ & $21.0 \%$ & $23.4 \%$ \\
\hline Source: OECD (2013), Teaching and Learning International Survey (TALIS): 2013 complete database,
\end{tabular}

http://stats.oecd.org/index.aspx?datasetcode=talis $2013 \% 20$.

Table 13 below shows the percentage of teachers in each Cluster at different levels of participation in school embedded professional development. Again, with one being a low level of participation and four being a high level of participation, we see that teachers in the teacher-led (23.8\%) and leader-led (23.3\%) clusters have the lowest levels of participation in school embedded professional development. Teachers in the balanced, collaborative cluster (Cluster 3) report the highest levels of participation in school embedded professional development (37.1\%). Teachers in the leader-dominant cluster (Cluster 4) also report higher levels of participation in school embedded professional development (29\%) than teachers in either the teacher- (Cluster 1) or leader-led (Cluster 2) clusters, but lower than teachers in the balanced, collaborative cluster (Cluster 3).

Table 13. Percentage of teachers in each cluster participating in school embedded professional development, by level of participation

\begin{tabular}{|c|c|c|c|c|}
\hline \multirow[t]{2}{*}{ Level of teacher participation } & \multicolumn{4}{|c|}{ School embedded professional development by cluster } \\
\hline & $1-$ teacher led & 2 - leader led & $\begin{array}{l}3 \text { - balanced, } \\
\text { collaborative }\end{array}$ & $\begin{array}{l}4 \text { - leader } \\
\text { dominant }\end{array}$ \\
\hline $1=$ low & $38.6 \%$ & $37.5 \%$ & $27.9 \%$ & $35.1 \%$ \\
\hline 2 & $37.7 \%$ & $39.2 \%$ & $35.0 \%$ & $35.9 \%$ \\
\hline 3 & $18.1 \%$ & $17.7 \%$ & $24.9 \%$ & $20.0 \%$ \\
\hline $4=$ high & $5.7 \%$ & $5.6 \%$ & $12.2 \%$ & $9.0 \%$ \\
\hline
\end{tabular}

The same pattern across the cluster types emerges when we consider teacher reports of instructional impact from professional development participation. Table 14 below demonstrates that teachers in the balanced, collaborative cluster (Cluster 3) report the highest levels of instructional impact from professional development participation (58.6\%). Fewer teachers in the teacher- (Cluster 1, 50.6\%) and leader-led (Cluster 2, 50.6\%) clusters report high levels of professional development impact and greater numbers of them report low levels of instructional impact from professional development participation. 
Table 14. Percentage of teachers reporting instructional impact from professional development participation, by level within each cluster

\begin{tabular}{|c|c|c|c|c|}
\hline \multirow{2}{*}{$\begin{array}{l}\text { Level of reported instructional } \\
\text { impact }\end{array}$} & \multicolumn{3}{|c|}{$\begin{array}{c}\text { Percentage of teachers reporting professional development } \\
\text { impact by cluster }\end{array}$} \\
\cline { 2 - 5 } & $1-$ teacher led & $2-$ leader led & $\begin{array}{c}3-\text { balanced, } \\
\text { collaborative }\end{array}$ & $\begin{array}{c}4-\text { leader } \\
\text { dominant }\end{array}$ \\
\hline $1=$ low & $32.2 \%$ & $32.3 \%$ & $27.0 \%$ & $30.2 \%$ \\
\hline 2 & $17.1 \%$ & $17.1 \%$ & $14.4 \%$ & $16.0 \%$ \\
\hline $3=$ high & $50.6 \%$ & $50.6 \%$ & $58.6 \%$ & $53.8 \%$ \\
\hline
\end{tabular}

Source: OECD (2013), Teaching and Learning International Survey (TALIS): 2013 complete database, http://stats.oecd.org/index.aspx?datasetcode=talis $2013 \% 20$.

Table 15. Percentage of teachers in cluster, by system from TALIS 2013

\begin{tabular}{|c|c|c|c|c|}
\hline \multirow[b]{2}{*}{ System } & \multicolumn{4}{|c|}{ Percentage of Teachers in Each Cluster } \\
\hline & $\begin{array}{l}3 \text { - balanced, } \\
\text { collaborative }\end{array}$ & 4 - leader dominant & 1 - teacher-led & 2 - leader led \\
\hline Romania & 59.5 & 15.2 & 7.2 & 11.8 \\
\hline Abu Dhabi (United Arab Emirates) & 45.6 & 21.8 & 2.5 & 16.6 \\
\hline Portugal & 44.6 & 7.9 & 24.3 & 19 \\
\hline England (United Kingdom) & 37.7 & 17.3 & 14.7 & 27.6 \\
\hline Bulgaria & 36.7 & 14.6 & 8.1 & 39.1 \\
\hline Australia & 33.7 & 11 & 16.8 & 36 \\
\hline Slovak Republic & 33.2 & 18.3 & 10.6 & 36.1 \\
\hline Denmark & 33 & 3.5 & 38.2 & 22.4 \\
\hline Chile & 32.5 & 26.7 & 6.4 & 30.1 \\
\hline Alberta (Canada) & 32.3 & 22.9 & 14.2 & 28.1 \\
\hline Serbia & 32.1 & 15.6 & 11.3 & 38.9 \\
\hline Poland & 31.4 & 9.8 & 18.2 & 39.6 \\
\hline Israel & 30.7 & 15.1 & 17.7 & 30.7 \\
\hline Iceland & 28.8 & 8.5 & 23.8 & 37.6 \\
\hline Flanders (Belgium) & 28.3 & 2.7 & 42.6 & 24.6 \\
\hline Italy & 28.2 & 6.4 & 29 & 35.1 \\
\hline Total mean & 27.7 & 13.6 & 24.5 & 34.3 \\
\hline Brazil & 27.5 & 22.1 & 15 & 33.7 \\
\hline Croatia & 26.8 & 6.2 & 28.2 & 37.6 \\
\hline Latvia & 25.7 & 8.2 & 16.8 & 48.7 \\
\hline France & 21.8 & 7.2 & 32.5 & 38 \\
\hline Singapore & 20.2 & 24.8 & 12.7 & 41.1 \\
\hline Spain & 20.2 & 10.1 & 35.5 & 32.6 \\
\hline Netherlands & 19.9 & 7.1 & 27.8 & 44.4 \\
\hline Mexico & 19.8 & 33.1 & 12.2 & 32.9 \\
\hline Sweden & 19.6 & 5 & 44.8 & 29.6 \\
\hline Norway & 14.1 & 4.9 & 36.4 & 44.4 \\
\hline Czech Republic & 13.4 & 9.9 & 27.8 & 48.2 \\
\hline Finland & 12.8 & 2 & 53.4 & 31.3 \\
\hline Estonia & 12.4 & 3.6 & 47.7 & 35.2 \\
\hline Korea & 11.2 & 22.4 & 17 & 48.2 \\
\hline Japan & 1.9 & 1.3 & 68.8 & 27.8 \\
\hline
\end{tabular}


There are statistically significant differences between systems in the percentage of their teachers in each of these school clusters. Table 15, above, provides this information and is sorted to highlight the systems with the largest percentage of teachers in Cluster 3, the balanced, collaborative schools. The percentages of teachers in the leader-dominant schools are shown second with percentages of teachers in teacher-led and leader-led schools appearing last.

Figure 8, below, shows these results graphically. It illustrates that some systems such as Abu Dhabi (United Arab Emirates), Portugal and Romania, have a statistically significant, greater proportion of teachers in Cluster 3 - balanced, co-operative schools - than other systems. While overall there tend to be fewer teachers in leader dominated (Cluster 4) schools in most systems; Abu Dhabi, United Arab Emirates; Alberta, Canada; Brazil; Chile; Korea; and Mexico are exceptions to this trend and all have higher than average numbers of teachers in Cluster 4 schools. As shown previously, the majority of teachers work in Cluster 2 - leader-led - schools; however, the Czech Republic, Korea, Netherlands, Norway, and Singapore have significantly more teachers in these schools than many other systems. Flanders, Belgium; Finland; Japan; and Sweden have a significantly larger percentage of teachers in Cluster 1 - teacher-led schools than in other systems. Thus, some systems have higher percentages of teachers in schools with conditions that support both teacher participation in school embedded professional development and the higher level of impact on classroom practice that is associated with these activities, while other systems have a higher percentage of teachers in less supportive schools. 
Figure 8. Illustration of the distribution of teachers across the clusters in each system graphically

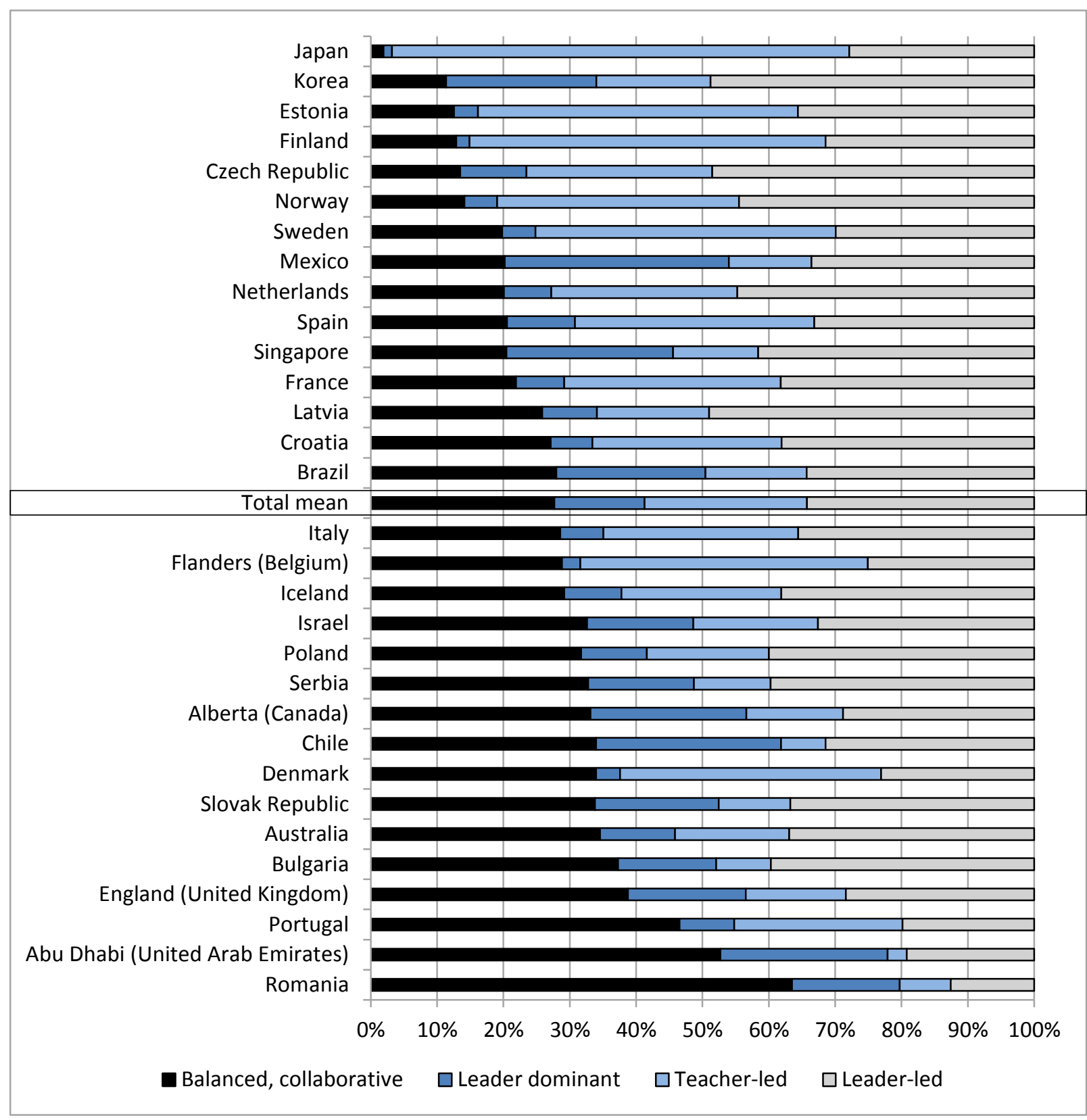

Source: OECD (2013), Teaching and Learning International Survey (TALIS): 2013 complete database, http://stats.oecd.org/index.aspx?datasetcode=talis 2013\%20.

\section{How can policy makers support teacher professional development that improves teaching?}

The patterns in the TALIS 2013 data are consistent with the available literature on effective professional development. As shown in other studies, teachers in TALIS reported lower participation rates in the kinds of professional development that has shown to be effective. Teachers participate most often in non-school embedded professional development activities, such as workshops and qualification courses. They participate less often in school embedded professional development that involves teacher collaboration on activities within their school. 
These differences in participation of teachers in these two types of professional development matters. Participation in school embedded professional development is positively associated with teacher reports of professional development impact; whereas participation in non-school embedded professional development is negatively associated with teacher reported impact of professional development. This would indicate that the more teachers participate in these non-school embedded forms of professional development the less likely it is that they will be positively impacted.

In addition to the type of professional development making a difference for teachers' professional learning, their instructional beliefs and school conditions also influence whether they will be impacted by professional learning activities. While teachers may learn new knowledge and skills by participating in professional development, whether or not they implement what they learn is dependent upon their own beliefs and the school environment. The analyses in this paper showed that teacher beliefs, such as feelings of preparedness, self-efficacy, constructivist pedagogical beliefs, and satisfaction with performance is associated with the reported impact of professional development. However, the relationship between these beliefs and reported impact of professional development is not always linear. When teachers have too little (for example, not being confident enough) or too much (being overly confident) of these beliefs, they can be less likely to implement new knowledge and skills in their classrooms. Teachers with moderate levels of these beliefs are the most likely to implement new knowledge and skills acquired through professional development.

Additionally, school conditions, such as teacher co-operation and the presence of instructionally focused leadership, can influence the impact of professional development for teachers. Taken together, these school conditions create four different profiles of schools:

1. teacher-led schools with high levels of co-operation and low levels of instructional leadership

2. leader-led schools with low levels of co-operation and moderate levels of instructional leadership

3. balanced, collaborative schools that are characterised by high levels of both co-operation and instructional leadership

4. leader-dominant schools with very high levels of instructional leadership, but low levels of cooperation among teachers.

These school types are associated with teachers' beliefs about themselves, with those in teacher- and leader-led schools reporting low levels of preparedness, self-efficacy, constructivist pedagogical beliefs and satisfaction. Those in leader-dominant schools reported moderate levels of these beliefs, while those in balanced, collaborative schools reported high levels of these beliefs. These types of schools also matter for both the type of professional development in which teachers engage and the impacts these activities have. Teachers in teacher-led schools and leader-led schools report low levels of participation in school embedded professional development and low levels of impact from the activities. Teachers in leaderdominant schools report higher levels of participation in school embedded professional development and higher impact than either teacher- or leader-led schools. Teachers in balanced, collaborative schools report both the highest participation in school embedded professional development and the highest impact levels.

Thus, "effective" teacher professional development that has an impact on teachers' instructional practices are activities that take place in schools and allow teachers to work over time, in collaborative groups, on problems of practice. These types of activities are most likely to occur in schools that are characterised by co-operation amongst teachers and strong instructional leadership. Policy makers can encourage participation in more effective professional development by first attending to the culture of schools. Structures and processes are needed that encourage teachers to co-operate. This often means 
providing time and opportunity for teachers to do so. Policy makers should also emphasise and support leaders in ways that allow them to focus on instruction. This support may mean reducing the focus on the managerial aspects of the position and incentivising school leaders to work more closely with teachers. With the right school conditions in place, policy makers should also increase the amount and variation of school embedded professional development offerings. These activities may include teacher initiated research projects, teacher networks, observation of colleagues, and mentoring and coaching. Teacher participation in non-school embedded professional development should be limited and not make up the primary professional development offerings. By supporting the conditions and activities most associated with effective professional development, we can increase the likelihood that students are impacted positively.

\section{Summary of recommendations}

- Develop structures and processes that encourage teachers to co-operate.

- Emphasise and support the instructional focus of school leaders.

- Increase the amount and variation of school embedded professional development offerings.

- Non-school embedded professional development should be limited to situations where teachers need to develop new knowledge and used infrequently when teachers are expected to engage in new teaching techniques. 


\section{REFERENCES}

Anderson, J.R. et al. (2000), "Perspectives on learning, thinking and activity", Educational Researcher, Vol. 29(4), pp. 11-13.

Ball, D.L. (1988), "Knowledge and reasoning in mathematical pedagogy: Examining what prospective teachers bring to teacher education", unpublished doctoral dissertation, Michigan State University, East Lansing, Michigan.

Ball, D. L. (1997), "From the general to the particular: Knowing our students as learners of mathematics", Mathematics Teacher, Vol. 90(9), pp. 732-737.

Ball, D.L and D.K. Cohen (1999), "Developing practices, developing practitioners: Toward a practicebased theory of professional development", in G. Sykes and L. Darling-Hammond (eds.), Teaching as the Learning Profession: Handbook of Policy and Practice, Jossey-Bass, San Francisco, CA, pp. 30-32.

Birman, B. et al. (2007), "State and local implementation of the No Child Left Behind Act, volume IITeacher quality under NCLB: Interim report",U.S. Department of Education, Office of Planning, Evaluation and Policy Development, Policy and Program Studies Service, Washington, D.C., www.rand.org/content/dam/rand/pubs/reprints/2007/RAND_RP1283.pdf.

Borko, H. (2004), "Professional development and teacher learning: Mapping the terrain", Educational Researcher, Vol. 33(8), pp. 3-15.

Borko, H., et al. (1997), “Teachers' developing ideas and practices about mathematics performance assessment: Successes, stumbling blocks, and implications for professional development", Teaching and Teacher Education, Vol. 13(3), pp. 259-278.

Campoy, R.W, and A. Hoewisch (1998), "Moral and instructional influences of teachers in professional development schools", Professional Educator, Vol. 20(3), pp. 7-23.

Carpenter, T.P. et al. (1989), "Using knowledge of children's mathematical thinking in classroom teaching: An experimental study", American Educational Research Journal, Vol. 26, pp. 499-532.

Center for Educational Leadership, University of Washington (2015), "4 Dimensions of Instructional Leadership", http://info.k-12leadership.org/4-dimensions-of-instructional-leadership (accessed 24 January 2015).

Chester, M. and B.Q. Beaudin (1996), "Efficacy beliefs of newly hired teachers in urban schools", American Educational Research Journal, Vol. 33, pp. 233-257.

Cobb, P. and J. Bowers (1999), "Cognitive and situated learning perspectives in theory and practice", Educational Researcher, Vol. 28(2), pp. 4-15.

Cohen, D. K., and H. C. Hill (2001), Learning Policy: When State Education Reform Works, Yale University Press, New Haven, CT.

Cohen, D.K. and H.C. Hill (2000), "Instructional policy and classroom performance: The mathematics reform in California”, Teachers College Record, Vol. 102(2), pp. 294-343. 
Coleman, J.S. (1985), "Schools and the communities they serve", Phi Delta Kappan, Vol. 66, pp. 527-532.

Coleman, J.S. (1987), "Norms as social capital”, in G. Radnitzky and P. Bernholz (eds.), Economic Imperialism: The Economic Approach Applied Outside the Field of Economics, Paragon, New York, NY, pp. 133-155.

Coleman, J.S. (1990), Foundations of Social Theory, Harvard University Press, Cambridge, MA.

Darling-Hammond, L. and M.W. McLaughlin (1995), "Policies that support professional development in an era of reform", Phi Delta Kappan, Vol. 76(8), pp. 597-604.

Darling-Hammond, L. et al. (2009), "Professional Learning in the learning profession: A status report on teacher development in the United States and abroad", National Staff Development Council and the School Redesign Network at Stanford University, https://edpolicy.stanford.edu/sites/default/files/publications/professional-learning-learningprofession-status-report-teacher-development-us-and-abroad.pdf.

Day, C. and J. Sachs (2005), International handbook on the continuing professional development of teachers, Open University Press, McGraw-Hill, Maidenhead, Berkshire.

Desimone, L.M. et al. (2002), "Effects of professional development on teachers' instruction: Results from a three-year longitudinal study", Educational Evaluation and Policy Analysis, Vol. 24, No. 2, Summer 2002, pp. 81-112.

Elmore, R.F. and D. Burney (1997), "Investing in teacher learning: Staff development and instructional improvement: Community School District 2, New York City", National Commission on Teaching and America's Future and Consortium for Policy Research in Education, New York, N.Y.

Elmore, R.F. (2004), School Reform from the Inside Out,Harvard University Press, Cambridge, MA.

European Commission, Directorate-General for Education and Culture, (2005), "CPD for teachers and trainers", report of a Peer Learning Activity, held in Dublin, 26-29 September, 2005.

Fernandez, C. (2002), "Learning from Japanese approaches to professional development: The case of lesson study", Journal of Teacher Education, Vol. 53(5), p. 393.

Fishman, B.J. et al. (2003), "Linking teacher and student learning to improve professional development in systemic reform" Teaching and Teacher Education, Vol. 19, pp. 643-658.

Galloway, D. et al. (1982), "Sources of stress for classroom teachers", National Education, Vol. 64, pp. 166-169.

Gamage, D. and P. Hansson (2006), "A comparative study of profiles and perspectives on professional development of school leaders in Australia and Sweden", Education and Society, Vol. 24(3), pp. 61-81.

Garet, M.S. et al. (2001), "What makes professional development effective? Results from a national sample of teachers", American Educational Research Journal, Vol. 38(4), pp. 915-945. 
Greeno, J.G., A.M. Collins and L. Resnick (1996), "Cognition and learning”, in D. C. Berliner and R.C. Calfree (Eds.), Handbook of educational psychology (pp. 15-46), Simon \& Schuster Macmillan, New York, NY.

Gregoire, M. (2003), "Is it a challenge or a threat? A dual-process model of teachers' cognition and appraisal processes during conceptual change", Educational Psychology Review, Vol. 15(2), pp. 147-179.

Grider, A.T. (2008), "Elementary, middle, and high school teachers' perceptions of professional learning community and sense of efficacy", Dissertation Abstracts International Section A: Humanities and Social Sciences, Vol. 69(4-A).

Grove, C.M., P.J. Dixon and M.M. Pop (2009), "Research experiences for teachers: Influences related to expectancy and value of changes to practice in the American classroom", Professional Development in Education, Vol. 35(2), pp. 247-260.

Guskey, T.R. (2003). What makes professional development effective? Phi Delta Kappan, 84(10).

Guskey, T.R. (2002), "Professional development and teacher change", Teachers and Teaching: Theory and Practice, Vol. 8(3/4), pp. 381-391.

Guskey, T. and D. Sparks (2004), "Linking professional development to improvements in student learning", in E.M. Guyton and J.R. Dangel (eds.), Research Linking Teacher Preparation and Student Performance: Teacher Education Yearbook XII, Kendall/Hunt, Dubuque, IA, pp. 233-247.

Hardré, P. L. and D. Sullivan (2008), "Classroom environments and student differences: How they contribute to student motivation in rural high schools", Learning and Individual Differences, Vol. 18, p. 471.

Hargreaves, A. (1998), "The emotional practice of teaching", Teaching and Teacher Education, Vol. 14, pp. 835-854.

Harrison, C. et al. (2008), "Evidence-based professional development of science teachers in two countries", International Journal of Science Education, Vol. 30(5), pp. 577-591.

Hassel, E. (1999), Professional Development: Learning From the Best, North Central Regional Educational Laboratory (NCREL), Oak Brook, IL.

Hawley, W.D, and L. Valli (1998), "The essentials of effective professional development: A new Consensus", in L.S. Darling-Hammond and G. Sykes (eds.), The Heart of the Matter: Teaching as a Learning Profession, Jossey-Bass, San Francisco, pp. 86-124.

Hill, H.C. (2009), "Fixing teacher professional development", Phi Delta Kappan, Vol. 90, No. 7, March, pp. 470-477.

Higgins, J. and R. Parsons (2009), "A successful professional development model in mathematics: A system-wide New Zealand case”, Journal of Teacher Education, Vol. 60(3), pp. 231-242.

Hollingsworth, H. (1999), "Teacher professional growth: a study of primary teachers involved in mathematics professional development", thesis, http://works.bepress.com/hilary_hollingsworth/15/. 
Hord, S. (1997), "Professional learning communities: Communities of continuous inquiry and improvement", Southwest Educational Development Laboratory, Austin, TX, www.sedl.org/pubs/change34/plc-cha34.pdf.

Ingvarson, L. M. Meiers and A. Beavis (2005), "Factors affecting the impact of professional development programs on teachers' knowledge, practice, student outcomes and efficacy", Education Policy Analysis Archives, Vol. 13(10), pp. 1-28.

Ingvarson, L. (1998), "Professional development as the pursuit of professional standards: The standardsbased professional development system", Teaching and Teacher Education, Vol. 14(1), pp. 127-140.

James, M. et al. (2007), Improving Learning How to Learn: Classrooms, Schools and Networks, Routledge, London, UK.

Joyce, B., and E. Calhoun (1996), "School renewal: An inquiry, Not a prescription", in B. Joyce and E. Calhoun (eds.), Learning Experiences in School Renewal: An Exploration of Five Successful Programs, ERIC Clearinghouse on Educational Management, Eugene, OR, pp. 175-190

Joyce, B. and B. Showers (1995), Student Achievement through Staff Development: Fundamentals of School Renewal, 2nd edition, Longman, New York.

Jurow, S. (2009), "Cultivating self in the context of transformative professional development", Journal of Teacher Education, Vol. 60(3), pp. 277-290.

Keith, D. L. (2008), "Principal desirability for professional development", Dissertation Abstracts International Section A: Humanities and Social Sciences, Vol. 69(4-A).

Kennedy, M. (1998), "Form and substance of inservice teacher education”, Research Monograph No. 13, National Institute for Science Education, University of Wisconsin-Madison, Madison, WI.

Killion, J. (1999), "What works in the middle: Results-based staff development" National Staff Development Council, Oxford, $\mathrm{OH}$.

Knapp, M.S. (2003), "Professional development as policy pathway", Review of Research in Education, Vol. 27(1), pp. 109-157.

Kuskovski, V.D. (2008), "Relationship between professional development and teacher efficacy in teachers of international schools in Switzerland", Dissertation Abstracts International Section A: Humanities and Social Sciences, Vol. 69(2-A).

Lave, J. and E. Wenger (1991), Situated Learning: Legitimate Peripheral Participation, Cambridge University Press, Cambridge, UK.

Leinhardt, G. (1998), "On the messiness of overlapping goals and real settings", Issues in Education, Vol. 4(1), pp. 125-132.

Leithwood, K., R. Steinbach and D. Jantzi (2002), "School leadership and teachers' motivation to implement accountability policies", Educational Administration Quarterly, Vol. 38(1), pp. 94-119.

Loucks-Horsely, S. et al. (2003), Designing Professional Development for Teachers Of Science And Mathematics, Sage, Thousand Oaks, CA. 
Loucks-Horsley, S. and C. Matsumoto (1999), "Research on professional development for teachers of mathematics and science: The state of the scene", School Science and Mathematics, Vol. 99(5), pp. 258-271.

Loucks-Horsley, S., K. Stiles and P. Hewson (1996), "Principles of effective professional development for mathematics and science education: A synthesis of standards", NISE Brief, Vol. 1, No. 1, May, University of Wisconsin at Madison, National Institute for Science Education, Madison, WI, pp. 1-5.

Louis, K.S., H.M. Marks and S. Kruse (1996), "Professional community in restructuring schools", American Educational Research Journal, Vol. 33(4), pp. 757-798.

Loxley, A. et al. (2007), "The role of whole-school contexts in shaping the experiences and outcomes associated with professional development”, Journal of In-service Education, Vol. 33(3), p. 21.

Lydon, S. and C. King (2009), "Can a single, short continuing professional development workshop cause change in the classroom?", Professional Development in Education, Vol. 35(1), pp. 63-82.

McGill-Franzen, A. et al. (1999), "Putting books in the classroom seems necessary but not sufficient", The Journal of Educational Research, Vol. 93(2), pp. 67-74.

McLaughlin, M.W. and J.E. Talbert (2001), Professional Communities and the Work of High School Teaching, University Of Chicago Press, Chicago.

Meirinka, J.A. et al. (2009), "Understanding teacher learning in secondary education: The relations of teacher activities to changed beliefs about teaching and learning", Teaching and Teacher Education, Vol. 25(1), pp. 89-100.

Moore, F.M. (2008), "Positional identity and science teacher professional development", Journal of Research in Science Teaching, Vol. 45(6), pp. 684-710.

Mortimore, P. et al. (1990), School Matters: The Junior Years, Open Books, Wells, UK.

Mueller, J. et al. (2008), "Identifying discriminating variables between teachers who fully integrate computers and teachers with limited integration", Computers and Education, Vol. 51(4), pp. 1523-1537.

National Commission on Teaching \& America's Future (1996), What matters most: Teaching for America's future, National Commission on Teaching \& America's Future, New York, NY, http://nctaf.org/wp-content/uploads/WhatMattersMost.pdf.

Newman, F. and G. Wehlage (1997), "Successful school restructuring: A report to the public and educators by the Center on Organization and Restructuring of Schools", Wisconsin Center for Education Research, Madison, WI.

Nir, A.E. and R. Bogler (2008), "The antecedents of teacher satisfaction with professional development programs", Teaching and Teacher Education, Vol. 24(2), pp. 377-386.

Novak, D. and J.G. Knowles (1992), "Life histories and the transition to teaching as a second career", paper presented at the annual meeting of the American Educational Research Association, San Francisco, CA, 20-24 April 1992. 
OECD (2014), TALIS 2013 Results: An International Perspective on Teaching and Learning, TALIS, OECD Publishing, Paris, http://dx.doi.org/10.1787/9789264196261-en.

OECD (2013), Teaching and Learning International Survey (TALIS): 2013 complete database, http://stats.oecd.org/index.aspx?datasetcode=talis_2013\%20.

Opfer, V.D. and D. Pedder (2011), "Conceptualizing teacher professional learning”, Review of Educational Research, Vol. 81(3), pp. 376-407.

Pedder, D. (2006), "Organizational conditions that foster successful classroom promotion of learning how to learn", Research Papers in Education, Vol. 21, pp. 171-200.

Pedder, D., M. James J. MacBeath (2005), "How teachers value and practice professional learning", Research Papers in Education, Vol. 20, pp. 209-243.

Pedder, D. and J. MacBeath (2008), “Organisational learning approaches to school leadership and management: Teachers' values and perceptions of practice", School Effectiveness and School Improvement, Vol. 19, pp. 207-224.

Penuel, W. et al. (2007), "What makes professional development effective? Strategies that foster curriculum implementation", American Educational Research Journal, Vol. 44(4), pp. 921-958.

Pollard, A. (1985), The Social World of the Primary School, Holt, Reinhart \& Winston, London, UK.

Powell, R. and J. Birrell (1992), "The influence of prior experiences on pedagogical constructs of traditional and nontraditional preservice teachers", paper presented at the annual meeting of the American Educational Research Association, San Francisco, CA, 20-24 April 1992.

Raths, J. (2001), “Teachers' beliefs and teaching beliefs", Early Childhood Research \& Practice, Vol. 3(1),

Richardson, V. (2003a), "Preservice teachers' beliefs", in J. Raths and A.C. McAninch (eds.), Teacher Beliefs and Classroom Performance: The Impact of Teacher Education, Volume 6: Advances in Teacher Education, Information Age, Greenwich, CT, pp. 1-22.

Richardson, V. (2003b), "The dilemmas of professional development”, Phi Delta Kappan, Vol. 84(5), pp. 401-406.

Richardson, V. (1996), "The role of attitudes and beliefs in learning to teach", in J. Sikula (ed.), Handbook of Research on Teacher Education, Second Edition, Macmillan, New York, pp. 102-119.

Richardson, V. and P. Placier (2001), "Teacher change", in V. Richardson (ed.), Handbook of Research on Teaching, 4th edition, American Educational Research Association, Washington, DC, pp. 905-947.

Rodríguez, S. et al. (2014), “Teacher self-efficacy and its relationship with students' affective and motivational variables in higher education", European Journal of Education and Psychology, Vol. 7(2), July-December, pp. 107-120.

Rutter, M. et al. (1979), Fifteen Thousand Hours, Open Books, London, UK.

Sampson, R. J., J.D. Morenoff and F. Earls (1999), "Beyond social capital: Spatial dynamics of collective efficacy for children", American Sociology Review, Vol. 64, pp. 633-660. 
Saxe, G., M. Gearhart and N.S. Nasir (2001), "Enhancing students' understanding of Mathematics: A study of three contrasting approaches to professional support", Journal of Mathematics Teacher Education, Vol. 4, pp. 55-79.

Scribner, J.P. (1999), "Professional development: Untangling the influence of work context on teacher learning", Educational Administration Quarterly, Vol. 35(2), pp. 238-266.

Snow-Renner, R. and P. Lauer (2005), "Professional development analysis", MCREL Insights, MidContent Research for Education and Learning, Denver, CO.

Supovitz, J.A., D.P. Mayer and J.B. Kahle (2000), "Promoting inquiry based instructional practice: The longitudinal impact of professional development in the context of systemic reform", Educational Policy, Vol. 14(3), pp. 331-356.

Timperley, H. et al. (2007), “Teacher professional development: Best evidence synthesis iteration”, Ministry of Education, Wellington, New Zealand, http://educationcounts.edcentre.govt.nz/goto/BES.

Weiss, I.R. and B. Miller (2009), "Determining what we know and how well we know it: The promises and perils of knowledge management", presentation at Math and Science Partnership (MSP) Learning Network Conference: Research Findings in Teacher Education: New Approaches > Transformative Possibilities?, Washington, DC, January 25-27, 2009, http://hub.mspnet.org/index.cfm/msp conf 2009 .

Weiss, I.R. and J.D. Pasley (2009), Mathematics and Science for a Change: How to Design, Implement, and Sustain High-Quality Professional Development, Heinemann, Portsmouth, NH.

Weiss, I.R. and J.D. Pasley (2006), "Scaling up instructional improvement through teacher professional development: Insights from the local systemic change initiative", CPRE Policy Briefs, March, 2006, http://repository.upenn.edu/cpre policybriefs/32.

Wilson, S.M. and J. Berne (1999), "Teacher learning and the acquisition of professional knowledge: An examination of research on contemporary professional development", Review of Research in Education, Vol. 24, pp. 173-209.

Woods, P., B. Jeffery and G. Troman (1997), Restructuring Schools, Reconstructing Teachers, Open University Press, Buckingham, UK.

Woolfolk Hoy, A. and R. Burke-Spero (2005), "Changes in teacher efficacy during the early years if teaching: A comparison of four measures", Teaching and Teacher Education, Vol. 21, pp. 343-356.

Yoon, K. S. et al. (2007), "Reviewing the evidence on how teacher professional development affects student achievement", Issues \& Answers Report, REL 2007-No. 033,U.S. Department of Education, Institute of Education Sciences, National Center for Education Evaluation and Regional Assistance, Regional Educational Laboratory Southwest, Washington, DC, http://ies.ed.gov/ncee/edlabs/regions/southwest/pdf/rel 2007033.pdf.

Zambo, R. and D. Zambo (2008), “The impact of professional development in mathematics on teachers' individual and collective efficacy: The stigma of underperforming”, Teacher Education Quarterly, Vol. 35(1), pp. 159-168. 


\section{ANNEX: TECHNICAL APPENDIX}

The first step in conducting analyses presented in this paper was preparing the data. After removing teachers who had not participated in any professional development in the 12 months prior to the survey (approximately 3\%) the final sample for analysis was 102746 teachers (from 34 systems and economies). An analysis of missing data was then conducted and data were found to be missing at random. Fully conditioned specification (MCMC) was used with 10 iterations to create 5 imputed data files.

\section{Identifying factors related to professional development for use in analysis}

One of the five imputed data files was used for exploratory factor analysis in Amos V20. With a large sample size the $X^{2}$ goodness-of-fit measure becomes problematic; as a result, RMSEA (Root Mean Square Error of Approximation) was relied on to determine best model fit for factors. Factors with theoretical coherence and the lowest RMSEA identified in Amos were then confirmed with the other four data sets using confirmatory factor analysis with SPSS V20. Barlett scores were saved as new variables and used in subsequent analyses.

Using these procedures, five new factors were created:

- School conditions that support professional development

- Teacher beliefs that support professional development

- School embedded professional development

- Non-school embedded professional development

- Professional development impact on instruction.

The school conditions factor includes six items. Means and standard deviations for the items are in Table A.1 below. Factor loadings for each item and the factor fit statistics are shown in Table A.2.

Table A.1 Means and standard deviations for items in school conditions factor

\begin{tabular}{|l|c|c|}
\hline School conditions factor items & Mean & $\begin{array}{c}\text { Std. } \\
\text { deviation }\end{array}$ \\
\hline How often do you [teacher] exchange teaching materials with colleagues? & 2.24 & 0.733 \\
\hline $\begin{array}{l}\text { How often do you [teacher] engage in discussions about the learning development of } \\
\text { specific students? }\end{array}$ & 2.49 & 0.643 \\
\hline How often do you [teacher] attend team conferences? & 2.20 & 0.749 \\
\hline $\begin{array}{l}\text { How frequently did you [school leader] take action in supporting co-operation among } \\
\text { teachers? }\end{array}$ & 2.78 & 0.701 \\
\hline $\begin{array}{l}\text { How frequently did you [school leader] take action to ensure teachers feel } \\
\text { responsibility for improving teaching skills? }\end{array}$ & 2.84 & 0.693 \\
\hline $\begin{array}{l}\text { How frequently did you [school leader] take action to ensure teachers feel } \\
\text { responsibility for learning outcomes? }\end{array}$ & 2.96 & 0.699 \\
\hline $\begin{array}{l}\text { OECD (2013), Teaching and Learning International Survey (TALIS): } 2013 \\
\text { complete database, }\end{array}$
\end{tabular}


Table A.2 Factor item loadings and fit statistics for school conditions factor

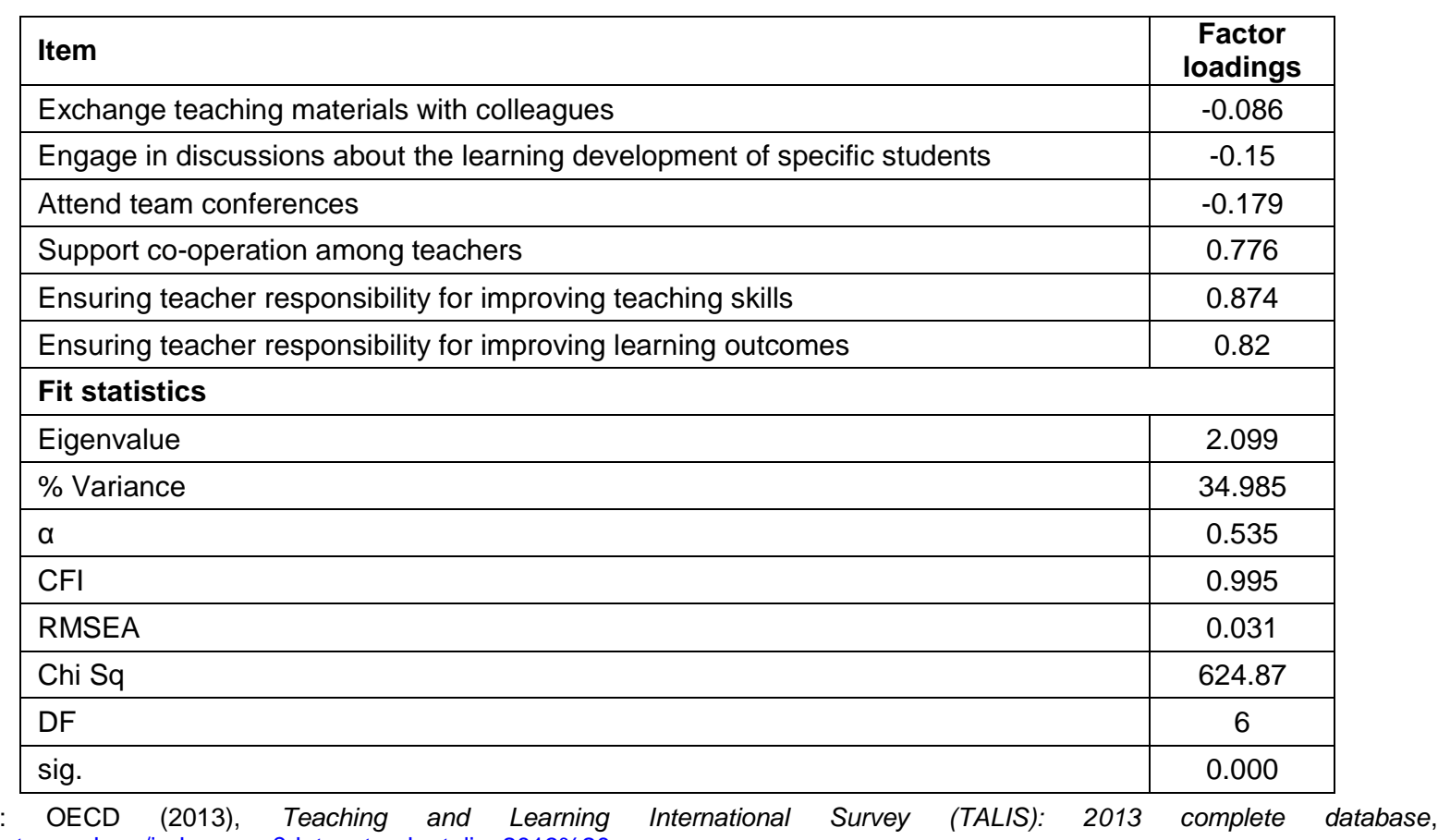

http://stats.oecd.org/index.aspx?datasetcode=talis $2013 \% 20$.

The teacher beliefs factor includes 16 items. Means and standard deviations for the items are in Table A.3 below. Factor loadings for each item and the factor fit statistics are shown in Table A.4.

Table A.3 Means and standard deviations for teacher belief items

\begin{tabular}{|l|c|c|}
\hline Items & Mean & $\begin{array}{c}\text { Std. } \\
\text { deviation }\end{array}$ \\
\hline Prepared for teaching content of the subject(s) I teach & 3.53 & 0.652 \\
\hline Prepared for teaching pedagogy of the subject(s) I teach & 3.30 & 0.702 \\
\hline Prepared for teaching classroom practice in the subject(s) I teach & 3.36 & 0.726 \\
\hline Extent to which you can craft good questions for students & 3.22 & 0.663 \\
\hline Extent to which you can control disruptive behaviour in the classroom & 3.25 & 0.692 \\
\hline Extent to which you can make expectations about student behaviour clear & 3.37 & 0.650 \\
\hline Extent to which you can get students to follow classroom rules & 3.29 & 0.661 \\
\hline Extent to which you can calm a student who is disruptive or noisy & 3.21 & 0.704 \\
\hline Extent to which you can use a variety of assessment strategies & 3.14 & 0.710 \\
\hline Extent to which you can provide an alternative explanation & 3.38 & 0.639 \\
\hline Extent to which you can implement alternative instructional strategies & 3.08 & 0.739 \\
\hline Believe role as a teacher is to facilitate students' own inquiry & 3.29 & 0.617 \\
\hline Believe students learn best by finding solutions to problems on their own & 3.10 & 0.695 \\
\hline Believe students should be allowed to think of solutions themselves & 3.23 & 0.624 \\
\hline Believe thinking and reasoning processes are more important & 3.08 & 0.697 \\
\hline Am satisfied with my performance in this school & 3.16 & 0.578 \\
\hline
\end{tabular}


Table A.4 Item loadings and fit statistics for teacher beliefs factor

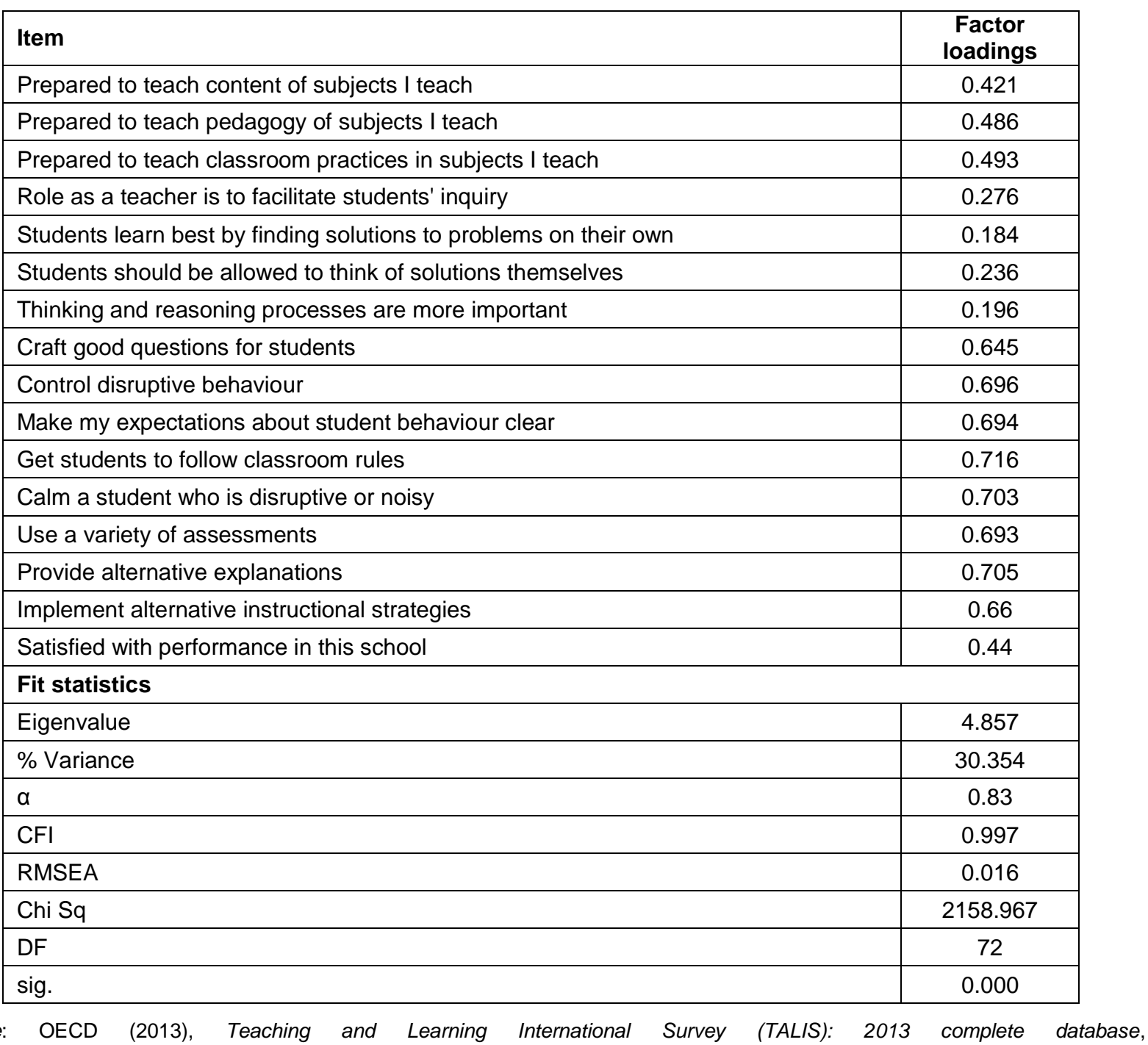

http://stats.oecd.org/index.aspx?datasetcode=talis 2013\%20.

The resulting teacher belief factor had negative skewness. A $\log 10$ transformation was conducted after which skewness was within acceptable estimates.

The school embedded professional development factor contains six items. Means and standard deviations for the items are in Table A.5 below. Factor loadings for each item and the factor fit statistics are shown in Table A.6. 
Table A.5 Means and standard deviations for items in school embedded professional development factor

\begin{tabular}{|c|c|c|}
\hline Items & Mean & $\begin{array}{c}\text { Std. } \\
\text { deviation }\end{array}$ \\
\hline Participation in a network of teachers & 1.34 & 0.473 \\
\hline Individual or collaborative research & 1.32 & 0.467 \\
\hline Mentoring and coaching & 1.29 & 0.453 \\
\hline Observe other teachers' classes and provide feedback & 1.42 & 0.635 \\
\hline Work with teachers to ensure common standards for assessing student progress & 2.19 & 0.738 \\
\hline Take part in collaborative professional learning & 1.79 & 0.702 \\
\hline
\end{tabular}

Table A.6 Factor loadings and fit statistics for school embedded professional development

\begin{tabular}{|c|c|}
\hline Item & $\begin{array}{c}\text { Factor } \\
\text { loadings }\end{array}$ \\
\hline Participation in a network of teachers & 0.52 \\
\hline Individual or collaborative research & 0.46 \\
\hline Mentoring and coaching & 0.59 \\
\hline Observe other teachers' classes and provide feedback & 0.54 \\
\hline Work with other teachers to ensure common standards for assessing progress & 0.55 \\
\hline Take part in collaborative professional learning & 0.67 \\
\hline Fit Statistics & \\
\hline Eigenvalue & 1.871 \\
\hline$\%$ Variance & 31.18 \\
\hline$\alpha$ & 0.554 \\
\hline CFI & 0.994 \\
\hline RMSEA & 0.023 \\
\hline Chi Sq & 285.902 \\
\hline DF & 5 \\
\hline sig. & 0.000 \\
\hline
\end{tabular}
Source: OECD (2013), Teaching and Learning
http://stats.oecd.org/index.aspx?datasetcode=talis $2013 \% 20$.

The non-school embedded professional development factor contains four items. Means and standard deviations for the items are in Table A.7 below. Factor loadings for each item and the factor fit statistics are shown in Table A.8. 
Table A.7 Means and standard deviations for non-school embedded factor items

\begin{tabular}{|l|c|c|}
\hline Items & Mean & $\begin{array}{c}\text { Std. } \\
\text { Deviation }\end{array}$ \\
\hline Courses and workshops & 1.33 & 0.471 \\
\hline Education conferences or seminars & 1.58 & 0.493 \\
\hline In-service training courses in business premises & 1.84 & 0.363 \\
\hline Qualification programme (e.g. a degree programme) & 1.80 & 0.402 \\
\hline
\end{tabular}

Source: OECD (2013), Teaching and Learning International Survey (TALIS): 2013 complete database, http://stats.oecd.org/index.aspx?datasetcode=talis $2013 \% 20$.

Table A.8 Factor loadings and fit statistics for non-school embedded factor

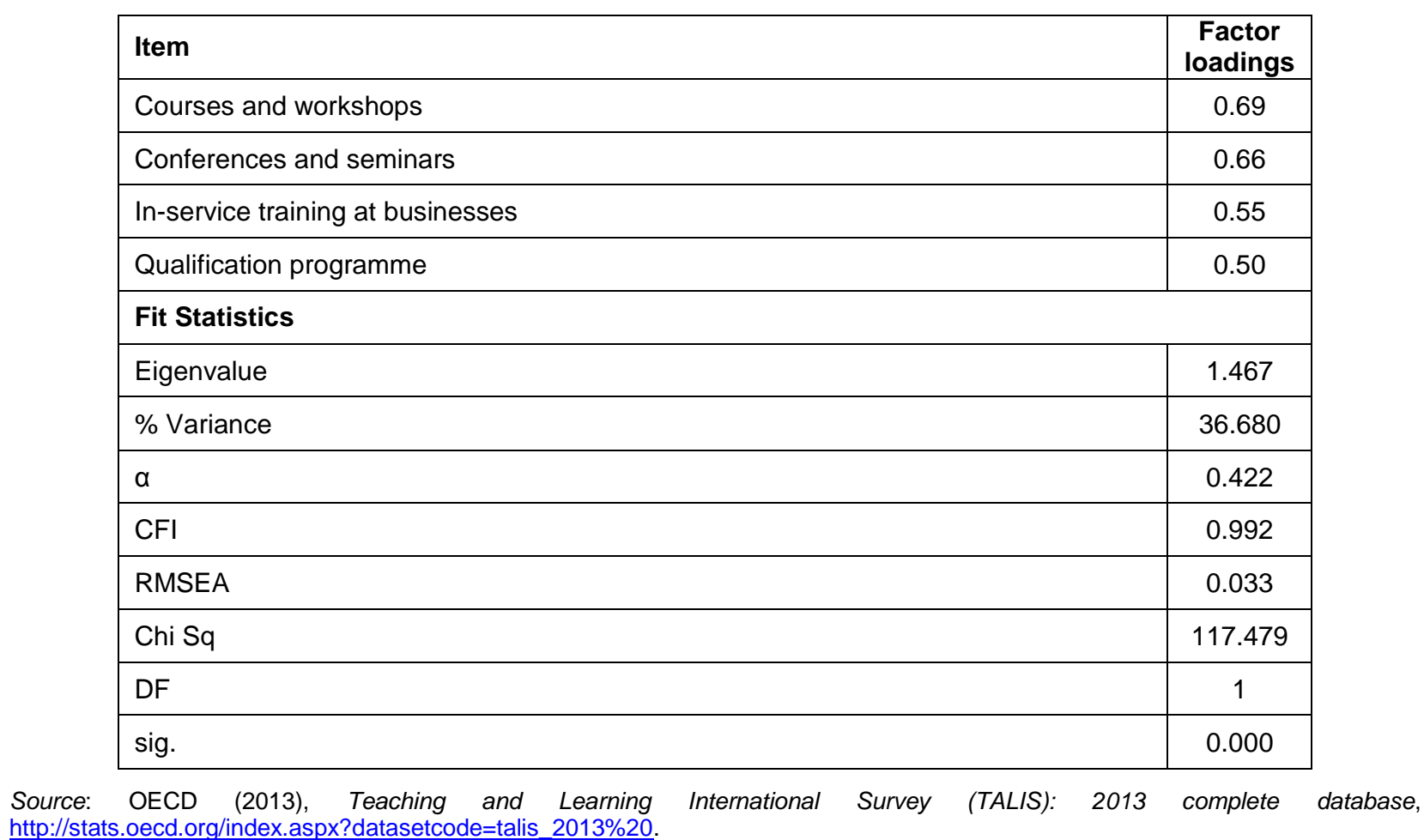

The factor for impact of professional development on instruction contains eight items. Means and standard deviations for the items are in Table A.9 below. Factor loadings for each item and the factor fit statistics are shown in Table A.10. 
Table A.9 Means and standard deviations for items in the professional development impact factor

\begin{tabular}{|l|c|c|}
\hline Items & Mean & $\begin{array}{c}\text { Std. } \\
\text { deviation }\end{array}$ \\
\hline Knowledge and understanding of my subject field(s) & 1.70 & 0.459 \\
\hline Pedagogical competences in teaching my subject fields(s) & 1.67 & 0.469 \\
\hline Professional development/Topic of activities/Knowledge of the curriculum/Impact & 1.66 & 0.475 \\
\hline Student evaluation and assessment practices & 1.64 & 0.479 \\
\hline ICT (information and communication technology) skills & 1.62 & 0.486 \\
\hline Student behaviour and classroom management & 1.62 & 0.486 \\
\hline Teaching cross-curricular skills & 1.61 & 0.488 \\
\hline Student career guidance and counselling & 1.60 & 0.490 \\
\hline
\end{tabular}

Source: OECD (2013), Teaching and Learning International Survey (TALIS): 2013 complete database, http://stats.oecd.org/index.aspx?datasetcode=talis 2013\%20.

Table A.10 Factor loadings and fit statistics for professional development impact factor

\begin{tabular}{|c|c|}
\hline ( & $\begin{array}{l}\text { Factor } \\
\text { loadings }\end{array}$ \\
\hline $\begin{array}{l}\text { Professional development had a positive impact on knowledge and understanding of } \\
\text { my subject field(s) }\end{array}$ & 0.885 \\
\hline $\begin{array}{l}\text { Professional development had a positive impact on pedagogical competencies in } \\
\text { teaching my subject field(s) }\end{array}$ & 0.883 \\
\hline Professional development had a positive impact on knowledge of the curriculum & 0.863 \\
\hline $\begin{array}{l}\text { Professional development had a positive impact on student evaluation and } \\
\text { assessment practices }\end{array}$ & 0.857 \\
\hline Professional development had a positive impact on ICT skills for teaching & 0.816 \\
\hline $\begin{array}{l}\text { Professional development had a positive impact on student behaviour and classroom } \\
\text { management }\end{array}$ & 0.846 \\
\hline $\begin{array}{l}\text { Professional development had a positive impact on teaching cross-curricular skills } \\
\text { (e.g. problem solving, learning-to-learn) }\end{array}$ & 0.844 \\
\hline $\begin{array}{l}\text { Professional development had a positive impact on student career guidance and } \\
\text { counselling }\end{array}$ & 0.828 \\
\hline \multicolumn{2}{|l|}{ Fit statistics } \\
\hline Eigenvalue & 5.820 \\
\hline$\%$ Variance & 72.744 \\
\hline$\alpha$ & 0.946 \\
\hline $\mathrm{CFI}$ & 0.999 \\
\hline RMSEA & 0.020 \\
\hline Chi Sq & 503.912 \\
\hline DF & 11 \\
\hline sig. & 0.000 \\
\hline
\end{tabular}

http://stats.oecd.org/index.aspx?datasetcode=talis $2013 \% 20$.

Eigenvalues and percent variance explained for each of the reported factors by system can be found in Table A.11 below. 
Table A.11 Fit statistics for each factor by system

\begin{tabular}{|c|c|c|c|c|c|c|c|c|c|c|}
\hline & \multicolumn{2}{|c|}{$\begin{array}{c}\text { School } \\
\text { conditions }\end{array}$} & \multicolumn{2}{|c|}{ Teacher beliefs } & \multicolumn{2}{|c|}{$\begin{array}{c}\text { Non-job } \\
\text { embedded PD }\end{array}$} & \multicolumn{2}{|c|}{$\begin{array}{c}\text { Job embedded } \\
\text { PD }\end{array}$} & \multicolumn{2}{|c|}{ PD impact } \\
\hline System & Eigen & $\%$ & Eigen & $\%$ & Eigen & $\%$ & Eigen & $\%$ & Eigen & $\%$ \\
\hline $\begin{array}{l}\text { Abu Dhabi } \\
\text { (United Arab } \\
\text { Emirates) }\end{array}$ & 2.328 & 38.80 & 4.858 & 32.38 & 1.770 & 44.24 & 2.436 & 40.60 & 6.080 & 76.00 \\
\hline $\begin{array}{l}\text { Alberta } \\
\text { (Canada) }\end{array}$ & 2.290 & 38.17 & 4.242 & 28.28 & 1.281 & 32.01 & 1.845 & 30.75 & 4.272 & 53.40 \\
\hline Australia & 2.325 & 38.75 & 4.529 & 30.20 & 1.358 & 33.95 & 1.832 & 30.53 & 4.442 & 55.52 \\
\hline Brazil & 2.145 & 35.75 & 4.163 & 27.75 & 1.704 & 42.61 & 1.933 & 32.22 & 6.020 & 75.26 \\
\hline Bulgaria & 1.840 & 30.67 & 3.720 & 24.80 & 1.746 & 43.67 & 1.827 & 30.46 & 6.363 & 79.54 \\
\hline Chile & 2.076 & 34.60 & 4.738 & 31.59 & 1.686 & 42.16 & 2.190 & 36.50 & 6.889 & 86.12 \\
\hline Croatia & 1.934 & 32.24 & 4.056 & 27.05 & 1.249 & 31.23 & 1.646 & 27.43 & 5.054 & 63.18 \\
\hline $\begin{array}{l}\text { Czech } \\
\text { Republic }\end{array}$ & 2.078 & 34.63 & 3.850 & 25.67 & 1.479 & 36.97 & 1.753 & 29.22 & 5.735 & 71.68 \\
\hline Denmark & 2.033 & 33.89 & 4.085 & 27.23 & 1.377 & 34.43 & 1.716 & 28.60 & 5.551 & 69.39 \\
\hline $\begin{array}{l}\text { England } \\
\text { (United } \\
\text { Kingdom) }\end{array}$ & 2.078 & 35.63 & 4.452 & 26.68 & 1.346 & 33.66 & 1.961 & 32.68 & 4.971 & 62.14 \\
\hline Estonia & 1.893 & 31.54 & 3.705 & 24.70 & 1.444 & 36.09 & 1.903 & 37.72 & 4.925 & 61.56 \\
\hline Finland & 1.922 & 32.04 & 3.941 & 26.27 & 1.314 & 32.84 & 1.746 & 29.10 & 5.471 & 68.39 \\
\hline $\begin{array}{l}\text { Flanders } \\
\text { (Belgium) }\end{array}$ & 2.213 & 36.89 & 3.827 & 25.51 & 1.260 & 31.50 & 1.653 & 27.54 & 5.497 & 68.71 \\
\hline France & 1.908 & 31.80 & 3.218 & 21.45 & 1.219 & 30.47 & 1.661 & 27.68 & 6.072 & 75.90 \\
\hline Iceland & 2.009 & 33.48 & 4.346 & 28.97 & 1.532 & 38.29 & 1.777 & 29.61 & 5.929 & 74.11 \\
\hline Israel & 2.140 & 35.67 & 4.340 & 28.93 & 1.335 & 33.37 & 1.887 & 31.45 & 5.771 & 72.14 \\
\hline Italy & 1.963 & 32.72 & 4.033 & 26.89 & 1.440 & 36.01 & 1.698 & 28.30 & 6.276 & 78.45 \\
\hline Japan & 2.044 & 34.06 & 4.731 & 31.54 & 1.463 & 36.57 & 1.946 & 32.43 & 6.107 & 76.33 \\
\hline Korea & 2.012 & 33.53 & 5.000 & 33.33 & 1.589 & 39.72 & 2.123 & 35.38 & 6.238 & 77.97 \\
\hline Latvia & 1.797 & 29.96 & 3.774 & 24.96 & 1.318 & 32.96 & 1.897 & 31.62 & 4.845 & 60.57 \\
\hline Mexico & 2.037 & 33.94 & 3.489 & 23.26 & 1.497 & 37.41 & 1.963 & 32.72 & 5.822 & 72.78 \\
\hline Netherlands & 1.993 & 33.22 & 3.681 & 34.54 & 1.369 & 34.23 & 1.748 & 29.14 & 4.965 & 62.06 \\
\hline Norway & 2.246 & 37.43 & 4.152 & 27.68 & 1.293 & 32.32 & 1.620 & 26.99 & 5.715 & 71.43 \\
\hline Poland & 1.806 & 30.11 & 4.145 & 27.63 & 1.421 & 35.52 & 1.805 & 30.08 & 5.168 & 64.61 \\
\hline Portugal & 2.123 & 35.38 & 3.971 & 26.47 & 1.512 & 37.81 & 1.505 & 25.08 & 6.293 & 78.66 \\
\hline Romania & 2.061 & 34.53 & 4.159 & 27.73 & 1.344 & 33.61 & 1.717 & 28.61 & 6.437 & 80.47 \\
\hline Serbia & 1.908 & 31.80 & 3.971 & 26.74 & 1.238 & 30.96 & 1.811 & 30.18 & 6.062 & 75.78 \\
\hline Singapore & 2.130 & 35.40 & 4.889 & 32.59 & 1.278 & 31.94 & 1.871 & 31.18 & 4.520 & 56.50 \\
\hline $\begin{array}{l}\text { Slovak } \\
\text { Republic }\end{array}$ & 1.830 & 30.50 & 4.038 & 26.92 & 1.444 & 36.11 & 1.841 & 30.68 & 6.624 & 82.80 \\
\hline Spain & 2.074 & 34.60 & 3.897 & 25.98 & 1.360 & 34.01 & 1.632 & 27.21 & 5.924 & 75.05 \\
\hline Sweden & 2.080 & 34.66 & 3.846 & 25.64 & 1.342 & 33.55 & 1.630 & 27.17 & 5.387 & 67.33 \\
\hline
\end{tabular}

http://stats.oecd.org/index.aspx?datasetcode=talis $2013 \% 20$.

Pearson, two-tailed correlation was used to understand the association between professional development type and teacher reported impact. These relationships reported by system appear in Table A.12 below. All correlations were significant for all systems at $\mathrm{p}<0.01$. 
Table A.12 Relationship between type of professional development and teacher reported impact, by system

\begin{tabular}{|l|c|c|}
\hline & \multicolumn{2}{|c|}{ Professional development impact } \\
\hline System & School embedded PD & Non-school embedded PD \\
\hline $\begin{array}{l}\text { Abu Dhabi (United Arab } \\
\text { Emirates) }\end{array}$ & 0.384 & -0.397 \\
\hline Alberta (Canada) & 0.172 & -0.152 \\
\hline Australia & 0.187 & -0.152 \\
\hline Brazil & 0.338 & -0.317 \\
\hline Bulgaria & 0.342 & -0.526 \\
\hline Chile & 0.273 & -0.519 \\
\hline Croatia & 0.304 & -0.292 \\
\hline Czech Republic & 0.297 & -0.515 \\
\hline Denmark & 0.293 & -0.457 \\
\hline England (United Kingdom) & 0.290 & -0.328 \\
\hline Estonia & 0.299 & -0.347 \\
\hline Finland & 0.264 & -0.476 \\
\hline Flanders (Belgium) & 0.188 & -0.447 \\
\hline France & 0.354 & -0.511 \\
\hline Iceland & 0.286 & -0.286 \\
\hline Israel & 0.309 & -0.326 \\
\hline Italy & 0.327 & -0.522 \\
\hline Japan & 0.464 & -0.469 \\
\hline Korea & 0.349 & -0.407 \\
\hline Latvia & 0.181 & -0.335 \\
\hline Mexico & 0.363 & -0.400 \\
\hline Netherlands & 0.276 & -0.326 \\
\hline Norway & 0.300 & -0.443 \\
\hline Poland & 0.288 & -0.378 \\
\hline Portugal & 0.314 & -0.478 \\
\hline Romania & 0.347 & -0.369 \\
\hline Serbia & 0.369 & -0.371 \\
\hline Singapore & 0.216 & -0.204 \\
\hline Slovak Republic & 0.407 & -0.566 \\
\hline Spain & 0.363 & -0.482 \\
\hline Sweden & 0.297 & -0.435 \\
\hline & & \\
\hline & & \\
\hline
\end{tabular}

Note: Pearson, two-tailed correlation. All results significant at $p<0.01$.

Source: OECD (2013), Teaching and Learning International Survey (TALIS): 2013 complete database, http://stats.oecd.org/index.aspx?datasetcode=talis 2013\%20.

Pearson, two-tailed correlation was used to understand the association between professional development type and teacher beliefs. These relationships reported by system appear in Table A.13 below. All correlations were significant for all systems at $\mathrm{p}<0.01$. 
Table A.13 Correlation between type of PD and teacher belief, by system

\begin{tabular}{|l|c|c|}
\hline \multicolumn{1}{|c|}{ System } & \multicolumn{2}{|c|}{ Teacher belief } \\
\hline $\begin{array}{l}\text { Abu Dhabi (United Arab } \\
\text { Emirates) }\end{array}$ & School embedded PD & Non-school embedded PD \\
\hline Alberta (Canada) & 0.368 & -0.303 \\
\hline Australia & 0.215 & -0.083 \\
\hline Brazil & 0.221 & -0.117 \\
\hline Bulgaria & 0.210 & -0.175 \\
\hline Chile & 0.220 & -0.077 \\
\hline Croatia & 0.153 & -0.126 \\
\hline Czech Republic & 0.257 & -0.106 \\
\hline Denmark & 0.232 & -0.099 \\
\hline England (United Kingdom) & 0.136 & -0.103 \\
\hline Estonia & 0.246 & -0.143 \\
\hline Finland & 0.222 & -0.085 \\
\hline Flanders (Belgium) & 0.206 & -0.115 \\
\hline France & 0.167 & -0.080 \\
\hline Iceland & 0.106 & -0.077 \\
\hline Israel & 0.251 & -0.197 \\
\hline Italy & 0.283 & -0.122 \\
\hline Japan & 0.176 & -0.012 \\
\hline Korea & 0.192 & -0.091 \\
\hline Latvia & 0.302 & -0.183 \\
\hline Mexico & 0.221 & -0.138 \\
\hline Netherlands & 0.202 & -0.109 \\
\hline Norway & 0.190 & -0.091 \\
\hline Poland & 0.199 & -0.123 \\
\hline Portugal & 0.179 & -0.056 \\
\hline Romania & 0.208 & -0.139 \\
\hline Serbia & 0.254 & -0.098 \\
\hline Singapore & 0.246 & -0.098 \\
\hline Slovak Republic & 0.197 & -0.113 \\
\hline Spain & 0.217 & -0.089 \\
\hline Sweden & 0.215 & -0.103 \\
\hline & 0.172 & -0.074 \\
\hline & & \\
\hline & & \\
\hline & & \\
\hline & & \\
\hline & & \\
\hline
\end{tabular}

Note: Pearson, two-tailed correlation. All results significant at $\mathrm{p}<.01$.

Source: OECD (2013), Teaching and Learning International Survey (TALIS): 2013 complete database, http://stats.oecd.org/index.aspx?datasetcode=talis 2013\%20.

Pearson, two-tailed correlation was used to understand the association between professional development type and school conditions. These relationships reported by system appear in Table A.14 below. Significant correlations are all $\mathrm{p}<0.01$. 
Table A.14 Correlation between type of PD and school conditions, by system

\begin{tabular}{|c|c|c|}
\hline & \multicolumn{2}{|c|}{ School conditions } \\
\hline System & School embedded PD & Non-school embedded PD \\
\hline $\begin{array}{l}\text { Abu Dhabi (United Arab } \\
\text { Emirates) }\end{array}$ & -0.038 & -0.027 \\
\hline Alberta (Canada) & 0.218 & -0.043 \\
\hline Australia & 0.080 & 0.086 \\
\hline Brazil & 0.115 & -0.051 \\
\hline Bulgaria & 0.267 & -0.129 \\
\hline Chile & 0.145 & 0.041 \\
\hline Croatia & 0.155 & -0.076 \\
\hline Czech Republic & 0.020 & 0.017 \\
\hline Denmark & 0.114 & -0.075 \\
\hline England (United Kingdom) & 0.111 & -0.036 \\
\hline Estonia & $0.012^{x}$ & $-0.002^{x}$ \\
\hline Finland & 0.055 & $-0.009^{x}$ \\
\hline Flanders (Belgium) & $0.000^{x}$ & 0.028 \\
\hline France & 0.067 & -0.008 \\
\hline Iceland & 0.088 & $-0.030^{x}$ \\
\hline Israel & 0.245 & -0.093 \\
\hline Italy & 0.042 & 0.030 \\
\hline Japan & 0.067 & -0.032 \\
\hline Korea & 0.198 & -0.047 \\
\hline Latvia & 0.100 & -0.025 \\
\hline Mexico & 0.075 & -0.014 \\
\hline Netherlands & 0.200 & $-0.003^{x}$ \\
\hline Norway & 0.085 & -0.102 \\
\hline Poland & 0.165 & -0.039 \\
\hline Portugal & 0.082 & -0.034 \\
\hline Romania & 0.153 & -0.107 \\
\hline Serbia & -0.064 & 0.038 \\
\hline Singapore & $-0.015^{x}$ & $0.000^{x}$ \\
\hline Slovak Republic & 0.055 & $0.010^{x}$ \\
\hline Spain & 0.144 & -0.073 \\
\hline Sweden & 0.059 & $0.001^{x}$ \\
\hline
\end{tabular}

Note: Pearson, two-tailed correlation. ${ }^{x}$ indicates non-significant results.

Source: OECD (2013), Teaching and Learning International Survey (TALIS): 2013 complete database, http://stats.oecd.org/index.aspx?datasetcode=talis $2013 \% 20$. 


\section{Identifying school types and their relationship to professional development type and impact}

Both the teacher beliefs factor and the school conditions factor were used in a two-step cluster analysis to identify school types. The two-step procedure in SPSS was used because of the large sample size, a lack of clarity about the number of clusters present in the data, and the use of continuous variables in the analysis. Four clusters emerged with good model fit (silhouette measure of cohesion $=0.5$ ). The clusters had a ratio of 2.52 largest to smallest. Cluster one had $24.5 \%$ of teachers, cluster two $34.3 \%$, cluster three $27.7 \%$, and cluster four $13.6 \%$. Both the school embedded professional development and nonschool embedded professional development factors were used as evaluation factors in the model in order to see how each of the clusters identified varied for these two outcomes. All predictors in the model performed well: school conditions, teacher beliefs and school embedded professional development at 1.00 and non-school embedded professional development at 0.58 .

Analysis of variance was then used to compare item level responses by teachers between each of the identified clusters. Levene's test of homogeneity was significant for items related to both teacher co-operation and instructionally focused leadership. Welch test for equality of means is, therefore, reported below and is significant.

Table A.15 Welch test for equality of means for school conditions

\begin{tabular}{|l|c|c|c|c|}
\hline \multicolumn{5}{|c|}{ Welch robust tests of equality of means } \\
\hline & Statistic & df1 & df2 & Sig. \\
\hline $\begin{array}{l}\text { How often do teachers exchange teaching } \\
\text { materials with colleagues? }\end{array}$ & 390.244 & 4 & 14819.086 & 0.000 \\
\hline $\begin{array}{l}\text { How often do teachers engage in } \\
\text { discussions about the learning } \\
\text { development of specific students? }\end{array}$ & 662.534 & 4 & 14900.825 & 0.000 \\
\hline $\begin{array}{l}\text { How often do teachers attend team } \\
\text { conferences? }\end{array}$ & 643.053 & 4 & 14809.423 & 0.000 \\
\hline $\begin{array}{l}\text { How frequently did the school leader } \\
\text { engage in supporting co-operation among } \\
\text { teachers? }\end{array}$ & 20918.604 & 4 & 14497.403 & 0.000 \\
\hline $\begin{array}{l}\text { How frequently did the school leader } \\
\text { engage teachers in responsibility for } \\
\text { improving teaching skills? }\end{array}$ & 46967.253 & 4 & 14412.296 & 0.000 \\
\hline $\begin{array}{l}\text { How frequently did the school leader } \\
\text { engage teachers in responsibility for } \\
\text { learning outcomes? }\end{array}$ & 30988.862 & 4 & 14588.916 & 0.000 \\
\hline
\end{tabular}

Note: * Asymptotically F distributed.

Source: OECD (2013), Teaching and Learning International Survey (TALIS): 2013 complete database, http://stats.oecd.org/index.aspx?datasetcode=talis 2013\%20.

Tukey's HSD (honest significant difference) test indicates significant differences between clusters on most of the school conditions related items at the 0.05 level (see Table A.16 below). No difference in means was found between teachers in Clusters 2 and 3 on the item asking school leaders how often they engaged teachers in responsibility for learning outcomes. 
Table A.16 Tukey's HSD test for differences between clusters for school conditions

\begin{tabular}{|c|c|c|c|c|c|c|c|}
\hline \multicolumn{8}{|c|}{ Tukey HSD multiple comparisons } \\
\hline \multirow{2}{*}{\multicolumn{3}{|c|}{ Dependent variable }} & \multirow{3}{*}{$\begin{array}{c}\begin{array}{c}\text { Mean } \\
\text { difference } \\
(\mathrm{I}-\mathrm{J})\end{array} \\
0.080^{*}\end{array}$} & \multirow{3}{*}{$\begin{array}{l}\text { Std. } \\
\text { error }\end{array}$} & \multirow{3}{*}{$\begin{array}{l}\text { Sig. } \\
0.000\end{array}$} & \multicolumn{2}{|c|}{$\begin{array}{c}95 \% \text { confidence } \\
\text { interval }\end{array}$} \\
\hline & & & & & & \multirow{2}{*}{$\begin{array}{l}\text { Lower } \\
\text { bound }\end{array}$} & \multirow{2}{*}{$\begin{array}{c}\text { Upper } \\
\text { bound } \\
0.10 \\
\end{array}$} \\
\hline How often do teachers exchange teaching & \multirow[t]{3}{*}{1} & 2 & & & & & \\
\hline \multirow{11}{*}{ materials with colleagues? } & & 3 & $-0.099^{*}$ & 0.006 & 0.000 & -0.12 & -0.08 \\
\hline & & 4 & $0.137^{*}$ & 0.008 & 0.000 & 0.12 & 0.16 \\
\hline & \multirow[t]{3}{*}{2} & 1 & $-0.080^{*}$ & 0.006 & 0.000 & -0.10 & -0.06 \\
\hline & & 3 & $-0.179^{*}$ & 0.006 & 0.000 & -0.20 & -0.16 \\
\hline & & 4 & $0.057^{*}$ & 0.007 & 0.000 & 0.04 & 0.08 \\
\hline & \multirow[t]{3}{*}{3} & 1 & $0.099^{*}$ & 0.006 & 0.000 & 0.08 & 0.12 \\
\hline & & 2 & $0.179^{*}$ & 0.006 & 0.000 & 0.16 & 0.20 \\
\hline & & 4 & $0.236^{*}$ & 0.008 & 0.000 & 0.22 & 0.26 \\
\hline & \multirow[t]{3}{*}{4} & 1 & $-0.137^{*}$ & 0.008 & 0.000 & -0.16 & -0.12 \\
\hline & & 2 & $-0.057^{*}$ & 0.007 & 0.000 & -0.08 & -0.04 \\
\hline & & 3 & $-0.236^{*}$ & 0.008 & 0.000 & -0.26 & -0.22 \\
\hline \multirow{12}{*}{$\begin{array}{l}\text { How often do teachers engage in } \\
\text { discussions about the learning } \\
\text { development of specific students? }\end{array}$} & \multirow[t]{3}{*}{1} & 2 & $0.118^{*}$ & 0.005 & 0.000 & 0.10 & 0.13 \\
\hline & & 3 & $-0.065^{\star}$ & 0.006 & 0.000 & -0.08 & -0.05 \\
\hline & & 4 & $0.227^{*}$ & 0.007 & 0.000 & 0.21 & 0.25 \\
\hline & \multirow[t]{3}{*}{2} & 1 & $-0.118^{*}$ & 0.005 & 0.000 & -0.13 & -0.10 \\
\hline & & 3 & $-0.183^{*}$ & 0.005 & 0.000 & -0.20 & -0.17 \\
\hline & & 4 & $0.109^{*}$ & 0.006 & 0.000 & 0.09 & 0.13 \\
\hline & \multirow[t]{3}{*}{3} & 1 & $0.065^{*}$ & 0.006 & 0.000 & 0.05 & 0.08 \\
\hline & & 2 & $0.183^{*}$ & 0.005 & 0.000 & 0.17 & 0.20 \\
\hline & & 4 & $0.292^{*}$ & 0.007 & 0.000 & 0.27 & 0.31 \\
\hline & \multirow[t]{3}{*}{4} & 1 & $-0.227^{*}$ & 0.007 & 0.000 & -0.25 & -0.21 \\
\hline & & 2 & $-0.109^{*}$ & 0.006 & 0.000 & -0.13 & -0.09 \\
\hline & & 3 & $-0.292^{*}$ & 0.007 & 0.000 & -0.31 & -0.27 \\
\hline \multirow{12}{*}{$\begin{array}{l}\text { How often do teachers attend team } \\
\text { conferences? }\end{array}$} & \multirow[t]{3}{*}{1} & 2 & $0.197^{\star}$ & 0.006 & 0.000 & 0.18 & 0.21 \\
\hline & & 3 & $0.042^{*}$ & 0.006 & 0.000 & 0.02 & 0.06 \\
\hline & & 4 & $0.324^{*}$ & 0.008 & 0.000 & 0.30 & 0.35 \\
\hline & \multirow[t]{3}{*}{2} & 1 & $-0.197^{*}$ & 0.006 & 0.000 & -0.21 & -0.18 \\
\hline & & 3 & $-0.155^{*}$ & 0.006 & 0.000 & -0.17 & -0.14 \\
\hline & & 4 & $0.127^{*}$ & 0.007 & 0.000 & 0.11 & 0.15 \\
\hline & \multirow[t]{3}{*}{3} & 1 & $-0.042^{*}$ & 0.006 & 0.000 & -0.06 & -0.02 \\
\hline & & 2 & $0.155^{*}$ & 0.006 & 0.000 & 0.14 & 0.17 \\
\hline & & 4 & $0.282^{*}$ & 0.008 & 0.000 & 0.26 & 0.30 \\
\hline & \multirow[t]{3}{*}{4} & 1 & $-0.324^{*}$ & 0.008 & 0.000 & -0.35 & -0.30 \\
\hline & & 2 & $-0.127^{*}$ & 0.007 & 0.000 & -0.15 & -0.11 \\
\hline & & 3 & $-0.282^{*}$ & 0.008 & 0.000 & -0.30 & -0.26 \\
\hline
\end{tabular}


Table A.16 Tukey's HSD test for differences between clusters for school conditions - continued

\begin{tabular}{|c|c|c|c|c|c|c|c|}
\hline \multicolumn{8}{|c|}{ Tukey HSD multiple comparisons } \\
\hline \multirow{2}{*}{\multicolumn{3}{|c|}{ Dependent variable }} & \multirow{3}{*}{$\begin{array}{c}\begin{array}{c}\text { Mean } \\
\text { difference } \\
(\mathrm{I}-\mathrm{J})\end{array} \\
-0.741^{*}\end{array}$} & \multirow{3}{*}{$\begin{array}{l}\text { Std. } \\
\text { error }\end{array}$} & \multirow{3}{*}{$\begin{array}{l}\text { Sig. } \\
0.000\end{array}$} & \multicolumn{2}{|c|}{$\begin{array}{c}95 \% \text { confidence } \\
\text { interval }\end{array}$} \\
\hline & & & & & & \multirow{2}{*}{$\begin{array}{l}\text { Lower } \\
\text { bound } \\
-0.75\end{array}$} & \multirow{2}{*}{$\begin{array}{l}\text { Upper } \\
\text { bound } \\
-0.73\end{array}$} \\
\hline \multirow{12}{*}{$\begin{array}{l}\text { How frequently did the school leader } \\
\text { engage in supporting co-operation among } \\
\text { teachers? }\end{array}$} & \multirow[t]{3}{*}{1} & 2 & & & & & \\
\hline & & 3 & $-0.711^{*}$ & 0.005 & 0.000 & -0.72 & -0.70 \\
\hline & & 4 & $-1.538^{*}$ & 0.006 & 0.000 & -1.55 & -1.52 \\
\hline & \multirow[t]{3}{*}{2} & 1 & $0.741^{\star}$ & 0.004 & 0.000 & 0.73 & 0.75 \\
\hline & & 3 & $0.031^{*}$ & 0.004 & 0.000 & 0.02 & 0.04 \\
\hline & & 4 & $-0.797^{*}$ & 0.005 & 0.000 & -0.81 & -0.78 \\
\hline & \multirow[t]{3}{*}{3} & 1 & $0.711^{*}$ & 0.005 & 0.000 & 0.70 & 0.72 \\
\hline & & 2 & $-0.031^{*}$ & 0.004 & 0.000 & -0.04 & -0.02 \\
\hline & & 4 & $-0.827^{\star}$ & 0.006 & 0.000 & -0.84 & -0.81 \\
\hline & \multirow[t]{3}{*}{4} & 1 & $1.538^{*}$ & 0.006 & 0.000 & 1.52 & 1.55 \\
\hline & & 2 & $0.797^{*}$ & 0.005 & 0.000 & 0.78 & 0.81 \\
\hline & & 3 & $0.827^{*}$ & 0.006 & 0.000 & 0.81 & 0.84 \\
\hline \multirow{12}{*}{$\begin{array}{l}\text { How frequently did the school leader } \\
\text { engage teachers in responsibility for } \\
\text { improving teaching skills? }\end{array}$} & \multirow[t]{3}{*}{1} & 2 & $-0.920^{*}$ & 0.004 & 0.000 & -0.93 & -0.91 \\
\hline & & 3 & $-0.883^{*}$ & 0.004 & 0.000 & -0.89 & -0.87 \\
\hline & & 4 & $-1.806^{*}$ & 0.005 & 0.000 & -1.82 & -1.79 \\
\hline & \multirow[t]{3}{*}{2} & 1 & $0.920^{*}$ & 0.004 & 0.000 & 0.91 & 0.93 \\
\hline & & 3 & $0.038^{*}$ & 0.003 & 0.000 & 0.03 & 0.05 \\
\hline & & 4 & $-0.886^{*}$ & 0.004 & 0.000 & -0.90 & -0.87 \\
\hline & \multirow[t]{3}{*}{3} & 1 & $0.883^{*}$ & 0.004 & 0.000 & 0.87 & 0.89 \\
\hline & & 2 & $-0.038^{*}$ & 0.003 & 0.000 & -0.05 & -0.03 \\
\hline & & 4 & $-0.923^{*}$ & 0.004 & 0.000 & -0.94 & -0.91 \\
\hline & \multirow[t]{3}{*}{4} & 1 & $1.806^{*}$ & 0.005 & 0.000 & 1.79 & 1.82 \\
\hline & & 2 & $0.886^{\star}$ & 0.004 & 0.000 & 0.87 & 0.90 \\
\hline & & 3 & $0.923^{*}$ & 0.004 & 0.000 & 0.91 & 0.94 \\
\hline \multirow{12}{*}{$\begin{array}{l}\text { How frequently did the school leader } \\
\text { engage teachers in responsibility for } \\
\text { learning outcomes? }\end{array}$} & \multirow[t]{3}{*}{1} & 2 & $-0.834^{*}$ & 0.004 & 0.000 & -0.85 & -0.82 \\
\hline & & 3 & $-0.831^{*}$ & 0.004 & 0.000 & -0.84 & -0.82 \\
\hline & & 4 & $-1.641^{*}$ & 0.005 & 0.000 & -1.66 & -1.63 \\
\hline & \multirow[t]{3}{*}{2} & 1 & $0.834^{*}$ & 0.004 & 0.000 & 0.82 & 0.85 \\
\hline & & 3 & 0.003 & 0.004 & 0.939 & -0.01 & 0.01 \\
\hline & & 4 & $-0.807^{*}$ & 0.005 & 0.000 & -0.82 & -0.79 \\
\hline & \multirow[t]{3}{*}{3} & 1 & $0.831^{*}$ & 0.004 & 0.000 & 0.82 & 0.84 \\
\hline & & 2 & -0.003 & 0.004 & 0.939 & -0.01 & 0.01 \\
\hline & & 4 & $-0.810^{\star}$ & 0.005 & 0.000 & -0.82 & -0.80 \\
\hline & \multirow[t]{3}{*}{4} & 1 & $1.641^{*}$ & 0.005 & 0.000 & 1.63 & 1.66 \\
\hline & & 2 & $0.807^{*}$ & 0.005 & 0.000 & 0.79 & 0.82 \\
\hline & & 3 & $0.810^{*}$ & 0.005 & 0.000 & 0.80 & 0.82 \\
\hline
\end{tabular}

Note: * The mean difference is significant at the 0.05 level.

Source: OECD (2013), Teaching and Learning International Survey (TALIS): 2013 complete database, http://stats.oecd.org/index.aspx?datasetcode=talis 2013\%20. 
Analyses of variance were also run to consider differences in means between clusters for items related to teacher beliefs. The Levene Test was also significant for these items, therefore, Welch Robust Tests of Equality of Means are reported (see Table A.17 below) and all were significant.

\section{Table A.17 Welch test of equality of means for teacher beliefs}

\begin{tabular}{|c|c|c|c|c|}
\hline \multicolumn{5}{|c|}{ Welch robust tests of equality of means } \\
\hline & Statistic $^{\star}$ & df1 & df2 & Sig. \\
\hline Prepared for teaching content of the subject(s) I teach & 5425.439 & 4 & 22070.857 & 0.000 \\
\hline Prepared for teaching pedagogy of the subject(s) I teach & 8497.760 & 4 & 20062.112 & 0.000 \\
\hline $\begin{array}{l}\text { Prepared for teaching classroom practice in the subject(s) I } \\
\text { teach }\end{array}$ & 8127.535 & 4 & 20978.875 & 0.000 \\
\hline $\begin{array}{l}\text { To what extent can you craft good questions for my } \\
\text { students? }\end{array}$ & 13305.614 & 4 & 18309.833 & 0.000 \\
\hline $\begin{array}{l}\text { To what extent can you control disruptive behaviour in the } \\
\text { classroom? }\end{array}$ & 16413.279 & 4 & 20096.078 & 0.000 \\
\hline $\begin{array}{l}\text { To what extent can you make my expectations about } \\
\text { student behaviour clear? }\end{array}$ & 14258.068 & 4 & 19269.422 & 0.000 \\
\hline $\begin{array}{l}\text { To what extent can you get students to follow classroom } \\
\text { rules? }\end{array}$ & 18034.117 & 4 & 20244.640 & 0.000 \\
\hline $\begin{array}{l}\text { To what extent can you calm a student who is disruptive or } \\
\text { noisy? }\end{array}$ & 16778.269 & 4 & 19124.377 & 0.000 \\
\hline $\begin{array}{l}\text { To what extent can you use a variety of assessment } \\
\text { strategies? }\end{array}$ & 16609.686 & 4 & 18527.127 & 0.000 \\
\hline To what extent can you provide an alternative explanation? & 16258.257 & 4 & 19826.432 & 0.000 \\
\hline $\begin{array}{l}\text { To what extent can you implement alternative instructional } \\
\text { strategies? }\end{array}$ & 16393.555 & 4 & 18843.544 & 0.000 \\
\hline My role as a teacher is to facilitate students' own inquiry & 2987.335 & 4 & 16064.231 & 0.000 \\
\hline $\begin{array}{l}\text { Students learn best by finding solutions to problems on their } \\
\text { own }\end{array}$ & 1359.935 & 4 & 15208.130 & 0.000 \\
\hline Students should be allowed to think of solutions themselves & 2025.471 & 4 & 15487.767 & 0.000 \\
\hline Thinking and reasoning processes are more important & 1087.514 & 4 & 15106.391 & 0.000 \\
\hline I am satisfied with my performance in this school & 4978.975 & 4 & 15645.030 & 0.000 \\
\hline
\end{tabular}

Note: * Asymptotically F distributed.

Source: OECD (2013), Teaching and Learning International Survey (TALIS): 2013 complete database, http://stats.oecd.org/index.aspx?datasetcode=talis 2013\%20.

Tukey's HSD test indicates significant differences between clusters on all of the teacher belief related items at the 0.05 level (see Table A.18 below). 
Table A.18 Tukey's HSD test for differences between clusters for teacher beliefs

\begin{tabular}{|c|c|c|c|c|c|c|c|}
\hline \multicolumn{8}{|c|}{ Multiple comparisons } \\
\hline \multicolumn{3}{|l|}{ Tukey HSD } & \multirow{3}{*}{$\begin{array}{c}\text { Mean } \\
\text { difference } \\
(I-J)\end{array}$} & \multirow{3}{*}{$\begin{array}{l}\text { Std. } \\
\text { error }\end{array}$} & \multirow{3}{*}{ Sig. } & & \\
\hline \multirow{2}{*}{\multicolumn{3}{|c|}{ Dependent variable }} & & & & \multicolumn{2}{|c|}{$\begin{array}{l}95 \% \text { confidence } \\
\text { interval }\end{array}$} \\
\hline & & & & & & $\begin{array}{l}\text { Lower } \\
\text { bound }\end{array}$ & $\begin{array}{l}\text { Upper } \\
\text { bound }\end{array}$ \\
\hline \multirow{12}{*}{$\begin{array}{l}\text { Prepared for teaching content of the subject(s) I } \\
\text { teach }\end{array}$} & \multirow[t]{3}{*}{1} & 2 & $0.023^{*}$ & 0.005 & 0.000 & 0.01 & 0.04 \\
\hline & & 3 & $-0.362^{*}$ & 0.005 & 0.000 & -0.38 & -0.35 \\
\hline & & 4 & $-0.077^{*}$ & 0.007 & 0.000 & -0.09 & -0.06 \\
\hline & \multirow[t]{3}{*}{2} & 1 & $-0.023^{*}$ & 0.005 & 0.000 & -0.04 & -0.01 \\
\hline & & 3 & $-0.385^{*}$ & 0.005 & 0.000 & -0.40 & -0.37 \\
\hline & & 4 & $-0.100^{*}$ & 0.006 & 0.000 & -0.12 & -0.08 \\
\hline & \multirow[t]{3}{*}{3} & 1 & $0.362^{*}$ & 0.005 & 0.000 & 0.35 & 0.38 \\
\hline & & 2 & $0.385^{*}$ & 0.005 & 0.000 & 0.37 & 0.40 \\
\hline & & 4 & $0.285^{\star}$ & 0.007 & 0.000 & 0.27 & 0.30 \\
\hline & \multirow[t]{3}{*}{4} & 1 & $0.077^{*}$ & 0.007 & 0.000 & 0.06 & 0.09 \\
\hline & & 2 & $0.100^{*}$ & 0.006 & 0.000 & 0.08 & 0.12 \\
\hline & & 3 & $-0.285^{*}$ & 0.007 & 0.000 & -0.30 & -0.27 \\
\hline \multirow{12}{*}{$\begin{array}{l}\text { Prepared for teaching pedagogy of the } \\
\text { subject(s) I teach }\end{array}$} & \multirow[t]{3}{*}{1} & 2 & $0.053^{*}$ & 0.006 & 0.000 & 0.04 & 0.07 \\
\hline & & 3 & $-0.472^{*}$ & 0.006 & 0.000 & -0.49 & -0.46 \\
\hline & & 4 & $-0.097^{\star}$ & 0.007 & 0.000 & -0.12 & -0.08 \\
\hline & \multirow[t]{3}{*}{2} & 1 & $-0.053^{*}$ & 0.006 & 0.000 & -0.07 & -0.04 \\
\hline & & 3 & $-0.525^{*}$ & 0.005 & 0.000 & -0.54 & -0.51 \\
\hline & & 4 & $-0.149^{*}$ & 0.007 & 0.000 & -0.17 & -0.13 \\
\hline & \multirow[t]{3}{*}{3} & 1 & $0.472^{*}$ & 0.006 & 0.000 & 0.46 & 0.49 \\
\hline & & 2 & $0.525^{*}$ & 0.005 & 0.000 & 0.51 & 0.54 \\
\hline & & 4 & $0.376^{\star}$ & 0.007 & 0.000 & 0.36 & 0.39 \\
\hline & \multirow[t]{3}{*}{4} & 1 & $0.097^{*}$ & 0.007 & 0.000 & 0.08 & 0.12 \\
\hline & & 2 & $0.149^{*}$ & 0.007 & 0.000 & 0.13 & 0.17 \\
\hline & & 3 & $-0.376^{*}$ & 0.007 & 0.000 & -0.39 & -0.36 \\
\hline \multirow{12}{*}{$\begin{array}{l}\text { Prepared for teaching classroom practice in the } \\
\text { subject(s) I teach }\end{array}$} & \multirow[t]{3}{*}{1} & 2 & $0.055^{*}$ & 0.006 & 0.000 & 0.04 & 0.07 \\
\hline & & 3 & $-0.496^{*}$ & 0.006 & 0.000 & -0.51 & -0.48 \\
\hline & & 4 & $-0.123^{*}$ & 0.007 & 0.000 & -0.14 & -0.10 \\
\hline & \multirow[t]{3}{*}{2} & 1 & $-0.055^{*}$ & 0.006 & 0.000 & -0.07 & -0.04 \\
\hline & & 3 & $-0.552^{*}$ & 0.006 & 0.000 & -0.57 & -0.54 \\
\hline & & 4 & $-0.178^{*}$ & 0.007 & 0.000 & -0.20 & -0.16 \\
\hline & \multirow[t]{3}{*}{3} & 1 & $.0496^{*}$ & 0.006 & 0.000 & 0.48 & 0.51 \\
\hline & & 2 & $0.552^{*}$ & 0.006 & 0.000 & 0.54 & 0.57 \\
\hline & & 4 & $0.373^{*}$ & 0.007 & 0.000 & 0.35 & 0.39 \\
\hline & \multirow[t]{3}{*}{4} & 1 & $0.123^{*}$ & 0.007 & 0.000 & 0.10 & 0.14 \\
\hline & & 2 & $0.178^{\star}$ & 0.007 & 0.000 & 0.16 & .20 \\
\hline & & 3 & $-0.373^{*}$ & 0.007 & 0.000 & -0.39 & -0.35 \\
\hline
\end{tabular}


Table A.18 Tukey's HSD test for differences between clusters for teacher beliefs - continued

\begin{tabular}{|c|c|c|c|c|c|c|c|}
\hline \multicolumn{8}{|c|}{ Multiple comparisons } \\
\hline \multicolumn{3}{|l|}{ Tukey HSD } & \multirow{3}{*}{$\begin{array}{c}\text { Mean } \\
\text { difference } \\
(I-J)\end{array}$} & \multirow{3}{*}{$\begin{array}{l}\text { Std. } \\
\text { error }\end{array}$} & \multirow{3}{*}{ Sig. } & & \\
\hline \multirow{2}{*}{\multicolumn{3}{|c|}{ Dependent variable }} & & & & \multicolumn{2}{|c|}{$\begin{array}{c}95 \% \text { confidence } \\
\text { interval }\end{array}$} \\
\hline & & & & & & $\begin{array}{l}\text { Lower } \\
\text { bound }\end{array}$ & $\begin{array}{l}\text { Upper } \\
\text { bound }\end{array}$ \\
\hline \multirow{12}{*}{$\begin{array}{l}\text { To what extent can you craft good questions for } \\
\text { my students? }\end{array}$} & \multirow[t]{3}{*}{1} & 2 & $0.117^{*}$ & 0.005 & 0.000 & 0.10 & 0.13 \\
\hline & & 3 & $-0.589^{*}$ & 0.005 & 0.000 & -0.60 & -0.57 \\
\hline & & 4 & $-0.125^{*}$ & 0.006 & 0.000 & -0.14 & -0.11 \\
\hline & \multirow[t]{3}{*}{2} & 1 & $-0.117^{*}$ & 0.005 & 0.000 & -0.13 & -0.10 \\
\hline & & 3 & $-0.706^{*}$ & 0.005 & 0.000 & -0.72 & -0.69 \\
\hline & & 4 & $-0.241^{*}$ & 0.006 & 0.000 & -0.26 & -0.23 \\
\hline & \multirow[t]{3}{*}{3} & 1 & $0.589^{*}$ & 0.005 & 0.000 & 0.57 & 0.60 \\
\hline & & 2 & $0.706^{*}$ & 0.005 & 0.000 & 0.69 & 0.72 \\
\hline & & 4 & $0.464^{*}$ & 0.006 & 0.000 & 0.45 & 0.48 \\
\hline & \multirow[t]{3}{*}{4} & 1 & $0.125^{\star}$ & 0.006 & 0.000 & 0.11 & 0.14 \\
\hline & & 2 & $0.241^{*}$ & 0.006 & 0.000 & 0.23 & 0.26 \\
\hline & & 3 & $-0.464^{\star}$ & 0.006 & 0.000 & -0.48 & -0.45 \\
\hline \multirow{12}{*}{$\begin{array}{l}\text { To what extent can you control disruptive } \\
\text { behaviour in the classroom? }\end{array}$} & \multirow[t]{3}{*}{1} & 2 & $0.175^{*}$ & 0.005 & 0.000 & 0.16 & 0.19 \\
\hline & & 3 & $-0.631^{*}$ & 0.005 & 0.000 & -0.65 & -0.62 \\
\hline & & 4 & $-0.083^{*}$ & 0.006 & 0.000 & -0.10 & -0.07 \\
\hline & \multirow[t]{3}{*}{2} & 1 & $-0.175^{*}$ & 0.005 & 0.000 & -0.19 & -0.16 \\
\hline & & 3 & $-0.806^{*}$ & 0.005 & 0.000 & -0.82 & -0.79 \\
\hline & & 4 & $-0.258^{*}$ & 0.006 & 0.000 & -0.27 & -0.24 \\
\hline & \multirow[t]{3}{*}{3} & 1 & $0.631^{*}$ & 0.005 & 0.000 & 0.62 & 0.65 \\
\hline & & 2 & $0.806^{*}$ & 0.005 & 0.000 & 0.79 & 0.82 \\
\hline & & 4 & $0.548^{*}$ & 0.006 & 0.000 & 0.53 & 0.57 \\
\hline & \multirow[t]{3}{*}{4} & 1 & $0.083^{*}$ & 0.006 & 0.000 & 0.07 & 0.10 \\
\hline & & 2 & $0.258^{*}$ & 0.006 & 0.000 & 0.24 & 0.27 \\
\hline & & 3 & $-0.548^{*}$ & 0.006 & 0.000 & -0.57 & -0.53 \\
\hline \multirow{12}{*}{$\begin{array}{l}\text { To what extent can you make my expectations } \\
\text { about student behaviour clear? }\end{array}$} & \multirow[t]{3}{*}{1} & 2 & $0.140^{*}$ & 0.005 & 0.000 & 0.13 & 0.15 \\
\hline & & 3 & $-0.599^{*}$ & 0.005 & 0.000 & -0.61 & -0.59 \\
\hline & & 4 & $-0.094^{*}$ & 0.006 & 0.000 & -0.11 & -0.08 \\
\hline & \multirow[t]{3}{*}{2} & 1 & $-0.140^{*}$ & 0.005 & 0.000 & -0.15 & -0.13 \\
\hline & & 3 & $-0.739^{*}$ & 0.005 & 0.000 & -0.75 & -0.73 \\
\hline & & 4 & $-0.234^{*}$ & 0.006 & 0.000 & -0.25 & -0.22 \\
\hline & \multirow[t]{3}{*}{3} & 1 & $0.599^{*}$ & 0.005 & 0.000 & 0.59 & 0.61 \\
\hline & & 2 & $0.739^{*}$ & 0.005 & 0.000 & 0.73 & 0.75 \\
\hline & & 4 & $0.505^{\star}$ & 0.006 & 0.000 & 0.49 & 0.52 \\
\hline & \multirow[t]{3}{*}{4} & 1 & $0.094^{*}$ & 0.006 & 0.000 & 0.08 & 0.11 \\
\hline & & 2 & $0.234^{*}$ & 0.006 & 0.000 & 0.22 & 0.25 \\
\hline & & 3 & $-0.505^{*}$ & 0.006 & 0.000 & -0.52 & -0.49 \\
\hline
\end{tabular}


Table A.18 Tukey's HSD test for differences between clusters for teacher beliefs - continued

\begin{tabular}{|c|c|c|c|c|c|c|c|}
\hline \multicolumn{8}{|c|}{ Multiple comparisons } \\
\hline \multicolumn{3}{|l|}{ Tukey HSD } & \multirow{3}{*}{$\begin{array}{c}\text { Mean } \\
\text { difference } \\
(I-J)\end{array}$} & \multirow{3}{*}{$\begin{array}{l}\text { Std. } \\
\text { error }\end{array}$} & & & \\
\hline \multirow{2}{*}{\multicolumn{3}{|c|}{ Dependent variable }} & & & \multirow{2}{*}{ Sig. } & \multicolumn{2}{|c|}{$\begin{array}{l}95 \% \text { confidence } \\
\text { interval }\end{array}$} \\
\hline & & & & & & $\begin{array}{l}\text { Lower } \\
\text { bound }\end{array}$ & $\begin{array}{l}\text { Upper } \\
\text { bound }\end{array}$ \\
\hline \multirow{12}{*}{$\begin{array}{l}\text { To what extent can you get students to follow } \\
\text { classroom rules? }\end{array}$} & \multirow[t]{3}{*}{1} & 2 & $0.152^{*}$ & 0.005 & 0.000 & 0.14 & 0.17 \\
\hline & & 3 & $-0.649^{*}$ & 0.005 & 0.000 & -0.66 & -0.63 \\
\hline & & 4 & $-0.106^{*}$ & 0.006 & 0.000 & -0.12 & -0.09 \\
\hline & \multirow[t]{3}{*}{2} & 1 & $-0.152^{*}$ & 0.005 & 0.000 & -0.17 & -0.14 \\
\hline & & 3 & $-0.801^{*}$ & 0.005 & 0.000 & -0.81 & -0.79 \\
\hline & & 4 & $-0.258^{*}$ & 0.006 & 0.000 & -0.27 & -0.24 \\
\hline & \multirow[t]{3}{*}{3} & 1 & $0.649^{*}$ & 0.005 & 0.000 & 0.63 & 0.66 \\
\hline & & 2 & $0.801^{*}$ & 0.005 & 0.000 & 0.79 & 0.81 \\
\hline & & 4 & $0.543^{*}$ & 0.006 & 0.000 & 0.53 & 0.56 \\
\hline & \multirow[t]{3}{*}{4} & 1 & $0.106^{*}$ & 0.006 & 0.000 & 0.09 & 0.12 \\
\hline & & 2 & $0.258^{*}$ & 0.006 & 0.000 & 0.24 & 0.27 \\
\hline & & 3 & $-0.543^{*}$ & 0.006 & 0.000 & -0.56 & -0.53 \\
\hline \multirow{12}{*}{$\begin{array}{l}\text { To what extent can you calm a student who is } \\
\text { disruptive or noisy? }\end{array}$} & \multirow[t]{3}{*}{1} & 2 & $0.172^{*}$ & 0.005 & 0.000 & 0.16 & 0.19 \\
\hline & & 3 & $-0.668^{*}$ & 0.005 & 0.000 & -0.68 & -0.65 \\
\hline & & 4 & $-0.087^{*}$ & 0.006 & 0.000 & -0.11 & -0.07 \\
\hline & \multirow[t]{3}{*}{2} & 1 & $-0.172^{*}$ & 0.005 & 0.000 & -0.19 & -0.16 \\
\hline & & 3 & $-0.840^{*}$ & 0.005 & 0.000 & -0.85 & -0.83 \\
\hline & & 4 & $-0.259^{*}$ & 0.006 & 0.000 & -0.28 & -0.24 \\
\hline & \multirow[t]{3}{*}{3} & 1 & $0.668^{*}$ & 0.005 & 0.000 & 0.65 & 0.68 \\
\hline & & 2 & $0.840^{*}$ & 0.005 & 0.000 & 0.83 & 0.85 \\
\hline & & 4 & $0.581^{\star}$ & 0.006 & 0.000 & 0.56 & 0.60 \\
\hline & \multirow[t]{3}{*}{4} & 1 & $0.087^{*}$ & 0.006 & 0.000 & 0.07 & 0.11 \\
\hline & & 2 & $0.259^{*}$ & 0.006 & 0.000 & 0.24 & 0.28 \\
\hline & & 3 & $-0.581^{*}$ & 0.006 & 0.000 & -0.60 & -0.56 \\
\hline \multirow{12}{*}{$\begin{array}{l}\text { To what extent can you use a variety of } \\
\text { assessment strategies? }\end{array}$} & \multirow[t]{3}{*}{1} & 2 & $0.101^{*}$ & 0.005 & 0.000 & 0.09 & 0.11 \\
\hline & & 3 & $-0.719^{*}$ & 0.005 & 0.000 & -0.73 & -0.70 \\
\hline & & 4 & $-0.177^{*}$ & 0.007 & 0.000 & -0.19 & -0.16 \\
\hline & \multirow[t]{3}{*}{2} & 1 & $-0.101^{*}$ & 0.005 & 0.000 & -0.11 & -0.09 \\
\hline & & 3 & $-0.820^{*}$ & 0.005 & 0.000 & -0.83 & -0.81 \\
\hline & & 4 & $-0.277^{*}$ & 0.006 & 0.000 & -0.29 & -0.26 \\
\hline & \multirow[t]{3}{*}{3} & 1 & $0.719^{*}$ & 0.005 & 0.000 & 0.70 & 0.73 \\
\hline & & 2 & $0.820^{*}$ & 0.005 & 0.000 & 0.81 & 0.83 \\
\hline & & 4 & $0.543^{*}$ & 0.006 & 0.000 & 0.53 & 0.56 \\
\hline & \multirow[t]{3}{*}{4} & 1 & $0.177^{*}$ & 0.007 & 0.000 & 0.16 & 0.19 \\
\hline & & 2 & $0.277^{*}$ & 0.006 & 0.000 & 0.26 & 0.29 \\
\hline & & 3 & $-0.543^{*}$ & 0.006 & 0.000 & -0.56 & -0.53 \\
\hline
\end{tabular}


Table A.18 Tukey's HSD test for differences between clusters for teacher beliefs - continued

\begin{tabular}{|c|c|c|c|c|c|c|c|}
\hline \multicolumn{8}{|c|}{ Multiple comparisons } \\
\hline \multicolumn{3}{|l|}{ Tukey HSD } & \multirow{3}{*}{$\begin{array}{c}\text { Mean } \\
\text { difference } \\
(I-J)\end{array}$} & \multirow{3}{*}{$\begin{array}{l}\text { Std. } \\
\text { error }\end{array}$} & \multirow{3}{*}{ Sig. } & & \\
\hline \multirow{2}{*}{\multicolumn{3}{|c|}{ Dependent variable }} & & & & \multicolumn{2}{|c|}{$\begin{array}{c}95 \% \text { confidence } \\
\text { interval }\end{array}$} \\
\hline & & & & & & $\begin{array}{l}\text { Lower } \\
\text { bound }\end{array}$ & $\begin{array}{l}\text { Upper } \\
\text { bound }\end{array}$ \\
\hline \multirow{12}{*}{$\begin{array}{l}\text { To what extent can you provide an alternative } \\
\text { explanation? }\end{array}$} & \multirow[t]{3}{*}{1} & 2 & $0.143^{*}$ & 0.005 & 0.000 & 0.13 & 0.16 \\
\hline & & 3 & $-0.616^{*}$ & 0.005 & 0.000 & -0.63 & -0.60 \\
\hline & & 4 & $-0.110^{*}$ & 0.006 & 0.000 & -0.13 & -0.09 \\
\hline & \multirow[t]{3}{*}{2} & 1 & $-0.143^{*}$ & 0.005 & 0.000 & -0.16 & -0.13 \\
\hline & & 3 & $-0.759^{*}$ & 0.004 & 0.000 & -0.77 & -0.75 \\
\hline & & 4 & $-0.253^{*}$ & 0.006 & 0.000 & -0.27 & -0.24 \\
\hline & \multirow[t]{3}{*}{3} & 1 & $0.616^{*}$ & 0.005 & 0.000 & 0.60 & 0.63 \\
\hline & & 2 & $0.759^{*}$ & 0.004 & 0.000 & 0.75 & 0.77 \\
\hline & & 4 & $0.506^{*}$ & 0.006 & 0.000 & 0.49 & 0.52 \\
\hline & \multirow[t]{3}{*}{4} & 1 & $0.110^{*}$ & 0.006 & 0.000 & 0.09 & 0.13 \\
\hline & & 2 & $0.253^{*}$ & 0.006 & 0.000 & 0.24 & 0.27 \\
\hline & & 3 & $-0.506^{\star}$ & 0.006 & 0.000 & -0.52 & -0.49 \\
\hline \multirow{12}{*}{$\begin{array}{l}\text { To what extent can you implement alternative } \\
\text { instructional strategies? }\end{array}$} & \multirow[t]{3}{*}{1} & 2 & $0.156^{*}$ & 0.005 & 0.000 & 0.14 & 0.17 \\
\hline & & 3 & $-0.684^{*}$ & 0.006 & 0.000 & -0.70 & -0.67 \\
\hline & & 4 & $-0.136^{*}$ & 0.007 & 0.000 & -0.15 & -0.12 \\
\hline & \multirow[t]{3}{*}{2} & 1 & $-0.156^{*}$ & 0.005 & 0.000 & -0.17 & -0.14 \\
\hline & & 3 & $-0.840^{*}$ & 0.005 & 0.000 & -0.85 & -0.83 \\
\hline & & 4 & $-0.291^{*}$ & 0.007 & 0.000 & -0.31 & -0.27 \\
\hline & \multirow[t]{3}{*}{3} & 1 & $0.684^{*}$ & 0.006 & 0.000 & 0.67 & 0.70 \\
\hline & & 2 & $0.840^{*}$ & 0.005 & 0.000 & 0.83 & 0.85 \\
\hline & & 4 & $0.549^{*}$ & 0.007 & 0.000 & 0.53 & 0.57 \\
\hline & \multirow[t]{3}{*}{4} & 1 & $0.136^{*}$ & 0.007 & 0.000 & 0.12 & 0.15 \\
\hline & & 2 & $0.291^{*}$ & 0.007 & 0.000 & 0.27 & 0.31 \\
\hline & & 3 & $-0.549^{*}$ & 0.007 & 0.000 & -0.57 & -0.53 \\
\hline \multirow{12}{*}{$\begin{array}{l}\text { My role as a teacher is to facilitate students' } \\
\text { own inquiry }\end{array}$} & \multirow[t]{3}{*}{1} & 2 & $0.041^{*}$ & 0.005 & 0.000 & 0.03 & 0.05 \\
\hline & & 3 & $-0.233^{*}$ & 0.005 & 0.000 & -0.25 & -0.22 \\
\hline & & 4 & $-0.033^{*}$ & 0.006 & 0.000 & -0.05 & -0.02 \\
\hline & \multirow[t]{3}{*}{2} & 1 & $-0.041^{\star}$ & 0.005 & 0.000 & -0.05 & -0.03 \\
\hline & & 3 & $-0.274^{*}$ & 0.005 & 0.000 & -0.29 & -0.26 \\
\hline & & 4 & $-0.073^{*}$ & 0.006 & 0.000 & -0.09 & -0.06 \\
\hline & \multirow[t]{3}{*}{3} & 1 & $0.233^{*}$ & 0.005 & 0.000 & 0.22 & 0.25 \\
\hline & & 2 & $0.274^{*}$ & 0.005 & 0.000 & 0.26 & 0.29 \\
\hline & & 4 & $0.201^{*}$ & 0.006 & 0.000 & 0.18 & 0.22 \\
\hline & \multirow[t]{3}{*}{4} & 1 & $0.033^{*}$ & 0.006 & 0.000 & 0.02 & 0.05 \\
\hline & & 2 & $0.073^{*}$ & 0.006 & 0.000 & 0.06 & 0.09 \\
\hline & & 3 & $-0.201^{*}$ & 0.006 & 0.000 & -0.22 & -0.18 \\
\hline
\end{tabular}


Table A.18 Tukey's HSD test for differences between clusters for teacher beliefs - continued

\begin{tabular}{|c|c|c|c|c|c|c|c|}
\hline \multicolumn{8}{|c|}{ Multiple comparisons } \\
\hline \multicolumn{3}{|l|}{ Tukey HSD } & \multirow{3}{*}{$\begin{array}{c}\text { Mean } \\
\text { difference } \\
(I-J)\end{array}$} & \multirow{3}{*}{$\begin{array}{l}\text { Std. } \\
\text { error }\end{array}$} & \multirow{3}{*}{ Sig. } & & \\
\hline \multirow{2}{*}{\multicolumn{3}{|c|}{ Dependent variable }} & & & & \multicolumn{2}{|c|}{$\begin{array}{l}95 \% \text { confidence } \\
\text { interval }\end{array}$} \\
\hline & & & & & & $\begin{array}{l}\text { Lower } \\
\text { bound }\end{array}$ & $\begin{array}{l}\text { Upper } \\
\text { bound }\end{array}$ \\
\hline \multirow{12}{*}{$\begin{array}{l}\text { Students learn best by finding solutions to } \\
\text { problems on their own }\end{array}$} & \multirow[t]{3}{*}{1} & 2 & 0.004 & 0.006 & 0.960 & -0.01 & 0.02 \\
\hline & & 3 & $-0.198^{*}$ & 0.006 & 0.000 & -0.21 & -0.18 \\
\hline & & 4 & $-0.087^{*}$ & 0.007 & 0.000 & -0.11 & -0.07 \\
\hline & \multirow[t]{3}{*}{2} & 1 & -0.004 & 0.006 & 0.960 & -0.02 & 0.01 \\
\hline & & 3 & $-0.202^{*}$ & 0.006 & 0.000 & -0.22 & -0.19 \\
\hline & & 4 & $-0.091^{\star}$ & 0.007 & 0.000 & -0.11 & -0.07 \\
\hline & \multirow[t]{3}{*}{3} & 1 & $0.198^{*}$ & 0.006 & 0.000 & 0.18 & 0.21 \\
\hline & & 2 & $0.202^{*}$ & 0.006 & 0.000 & 0.19 & 0.22 \\
\hline & & 4 & $0.111^{*}$ & 0.007 & 0.000 & 0.09 & 0.13 \\
\hline & \multirow[t]{3}{*}{4} & 1 & $0.087^{\star}$ & 0.007 & 0.000 & 0.07 & 0.11 \\
\hline & & 2 & $0.091^{*}$ & 0.007 & 0.000 & 0.07 & 0.11 \\
\hline & & 3 & $-0.111^{*}$ & 0.007 & 0.000 & -0.13 & -0.09 \\
\hline \multirow{12}{*}{$\begin{array}{l}\text { Students should be allowed to think of solutions } \\
\text { themselves }\end{array}$} & \multirow[t]{3}{*}{1} & 2 & $0.022^{*}$ & 0.005 & 0.000 & 0.01 & 0.04 \\
\hline & & 3 & $-0.207^{*}$ & 0.005 & 0.000 & -0.22 & -0.19 \\
\hline & & 4 & $-0.057^{*}$ & 0.007 & 0.000 & -0.08 & -0.04 \\
\hline & \multirow[t]{3}{*}{2} & 1 & $-0.022^{*}$ & 0.005 & 0.000 & -0.04 & -0.01 \\
\hline & & 3 & $-0.230^{*}$ & 0.005 & 0.000 & -0.24 & -0.22 \\
\hline & & 4 & $-0.080^{*}$ & 0.006 & 0.000 & -0.10 & -0.06 \\
\hline & \multirow[t]{3}{*}{3} & 1 & $0.207^{*}$ & 0.005 & 0.000 & 0.19 & 0.22 \\
\hline & & 2 & $0.230^{*}$ & 0.005 & 0.000 & 0.22 & 0.24 \\
\hline & & 4 & $0.150^{*}$ & 0.006 & 0.000 & 0.13 & 0.17 \\
\hline & \multirow[t]{3}{*}{4} & 1 & $0.057^{*}$ & 0.007 & 0.000 & 0.04 & 0.08 \\
\hline & & 2 & $0.080^{*}$ & 0.006 & 0.000 & 0.06 & 0.10 \\
\hline & & 3 & $-0.150^{*}$ & 0.006 & 0.000 & -0.17 & -0.13 \\
\hline \multirow{12}{*}{$\begin{array}{l}\text { Thinking and reasoning processes are more } \\
\text { important }\end{array}$} & \multirow[t]{3}{*}{1} & 2 & $0.023^{*}$ & 0.006 & 0.001 & 0.01 & 0.04 \\
\hline & & 3 & $-0.168^{*}$ & 0.006 & 0.000 & -0.18 & -0.15 \\
\hline & & 4 & $-0.025^{*}$ & 0.007 & 0.005 & -0.05 & -0.01 \\
\hline & \multirow[t]{3}{*}{2} & 1 & $-0.023^{*}$ & 0.006 & 0.001 & -0.04 & -0.01 \\
\hline & & 3 & $-0.191^{*}$ & 0.006 & 0.000 & -0.21 & -0.18 \\
\hline & & 4 & $-0.048^{*}$ & 0.007 & 0.000 & -0.07 & -0.03 \\
\hline & \multirow[t]{3}{*}{3} & 1 & $0.168^{*}$ & 0.006 & 0.000 & 0.15 & 0.18 \\
\hline & & 2 & $0.191^{*}$ & 0.006 & 0.000 & 0.18 & 0.21 \\
\hline & & 4 & $0.143^{*}$ & 0.007 & 0.000 & 0.12 & 0.16 \\
\hline & \multirow[t]{3}{*}{4} & 1 & $0.025^{*}$ & 0.007 & 0.005 & 0.01 & 0.05 \\
\hline & & 2 & $0.048^{*}$ & 0.007 & 0.000 & 0.03 & 0.07 \\
\hline & & 3 & $-0.143^{*}$ & 0.007 & 0.000 & -0.16 & -0.12 \\
\hline
\end{tabular}


EDU/WKP(2016)12

Table A.18 Tukey's HSD test for differences between clusters for teacher beliefs - continued

\begin{tabular}{|c|c|c|c|c|c|c|c|}
\hline \multicolumn{8}{|c|}{ Multiple comparisons } \\
\hline \multicolumn{3}{|l|}{ Tukey HSD } & \multirow{3}{*}{$\begin{array}{c}\text { Mean } \\
\text { difference } \\
(I-J)\end{array}$} & \multirow{3}{*}{$\begin{array}{l}\text { Std. } \\
\text { error }\end{array}$} & & & \\
\hline \multirow{2}{*}{ Dependent variable } & & & & & \multirow{2}{*}{ Sig. } & \multicolumn{2}{|c|}{$\begin{array}{l}\text { 95\% confidence } \\
\text { interval }\end{array}$} \\
\hline & & & & & & $\begin{array}{l}\text { Lower } \\
\text { bound }\end{array}$ & $\begin{array}{l}\text { Upper } \\
\text { bound }\end{array}$ \\
\hline \multirow{12}{*}{$\begin{array}{l}\text { I am satisfied with my performance in this } \\
\text { school }\end{array}$} & \multirow[t]{3}{*}{1} & 2 & $0.051^{\star}$ & 0.005 & 0.000 & 0.04 & 0.06 \\
\hline & & 3 & $-0.332^{*}$ & 0.005 & 0.000 & -0.35 & -0.32 \\
\hline & & 4 & $-0.072^{*}$ & 0.006 & 0.000 & -0.09 & -0.06 \\
\hline & \multirow[t]{3}{*}{2} & 1 & $-0.051^{*}$ & 0.005 & 0.000 & -0.06 & -0.04 \\
\hline & & 3 & $-0.383^{*}$ & 0.004 & 0.000 & -0.40 & -0.37 \\
\hline & & 4 & $-0.123^{*}$ & 0.006 & 0.000 & -0.14 & -0.11 \\
\hline & \multirow[t]{3}{*}{3} & 1 & $0.332^{*}$ & 0.005 & 0.000 & 0.32 & 0.35 \\
\hline & & 2 & $0.383^{*}$ & 0.004 & 0.000 & 0.37 & 0.40 \\
\hline & & 4 & $0.260^{*}$ & 0.006 & 0.000 & 0.24 & 0.28 \\
\hline & \multirow[t]{3}{*}{4} & 1 & $0.072^{*}$ & 0.006 & 0.000 & 0.06 & 0.09 \\
\hline & & 2 & $0.123^{*}$ & 0.006 & 0.000 & 0.11 & 0.14 \\
\hline & & 3 & $-0.260^{*}$ & 0.006 & 0.000 & -0.28 & -0.24 \\
\hline
\end{tabular}

Note: * The mean difference is significant at the 0.05 level.

Source: OECD (2013), Teaching and Learning International Survey (TALIS): 2013 complete database, http://stats.oecd.org/index.aspx?datasetcode=talis $2013 \% 20$. 